\title{
Agents Unchained: The Determinants of Takeover Defenses in IPO Firms
}

\section{Citation}

Brandon Gold, Agents Unchained: The Determinants of Takeover Defenses in IPO Firms (June 2013).

\section{Permanent link}

http://nrs.harvard.edu/urn-3:HUL.InstRepos:10985171

\section{Terms of Use}

This article was downloaded from Harvard University's DASH repository, and is made available under the terms and conditions applicable to Other Posted Material, as set forth at http:// nrs.harvard.edu/urn-3:HUL.InstRepos:dash.current.terms-of-use\#LAA

\section{Share Your Story}

The Harvard community has made this article openly available.

Please share how this access benefits you. Submit a story.

Accessibility 


\title{
Agents UnCHAINED: THE DETERMINANTS OF TAKEOVER DEFENSES IN IPO FIRMS
}

\author{
Brandon S. Gold*
}

May 2013

\begin{abstract}
Many companies continue to go public with takeover defenses even though institutional investors zealously oppose defenses in public companies. In this Article, I analyze the determinants of takeover defenses at IPO firms using an empirical analysis of 259 IPOs from 2008-12, interviews with numerous practitioners, and a survey of the corporate governance policies of significant investors. I find that the type of an issuer's legal counsel's M\&A experience and the identity of pre-IPO shareholders explain much of the variation in takeover defenses at IPO firms. Companies advised by law firms with more target-side M\&A experience adopt more defenses, while companies advised by law firms with more acquirer-side M\&A experience adopt fewer defenses. Companies backed by venture capital funds are significantly more likely to adopt more takeover defenses. However, private equity backing has no effect on the pre-IPO adoption of staggered boards. Even though mutual funds and public pension funds are some of the most ardent opponents of takeover defenses in public companies, I find that issuers that they had invested in prior to the IPO almost always go public with robust takeover defenses in place. A comparison of issuers backed by Silicon Valley law firm Wilson Sonsini and New York law firm Simpson Thacher is particularly telling: Wilson Sonsini, a firm well known for its ties to the venture capital industry and its representation of targets, installed staggered boards in all of its IPO clients while Simpson Thacher, known for its private equity practice and acquirer representation, installed staggered boards in only $50 \%$ of its IPO clients. The lack of a consensus regarding the efficiency of defenses among the most experienced participants in the IPO market leads me to reject the idea that takeover defenses are generally optimal for pre-IPO shareholders.
\end{abstract}

JEL Classification: D21, G23, G24, G34, G38, K22

* J.D., Harvard Law School; Fellow, Program on Corporate Governance. E-mail: bgold@jd13.law.harvard.edu. I would like to thank Professor John C. Coates for his invaluable guidance and feedback throughout the drafting of this article. 


\section{TABle of Contents}

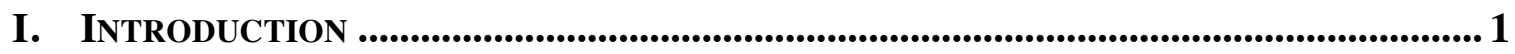

II. TAKeover Defenses in Public Companies ........................................................3 3

A. The Market for Corporate Control and Takeover Defenses at Public Companies .........3

1. Overview of classified boards and takeover defenses.................................................................

2. Opposition to takeover defenses at public companies............................................................... 8

B. Theories on the Determinants in Takeover Defenses at IPO Firms ..............................10

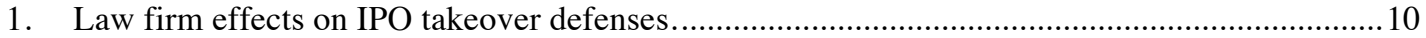

2. Institutional investors, financial sponsors, and IPO takeover defenses......................................... 14

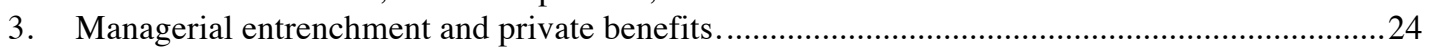

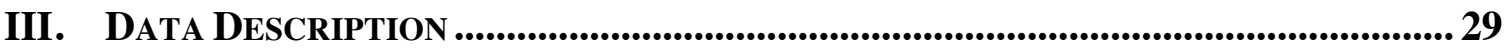

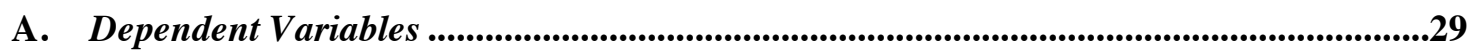

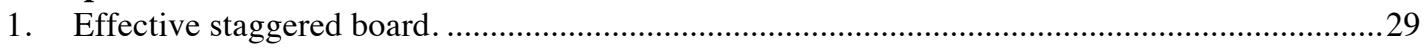

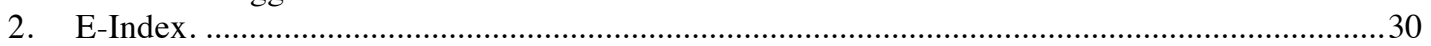

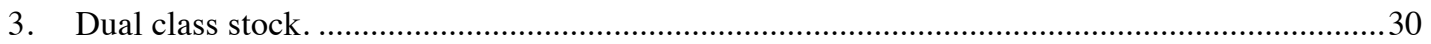

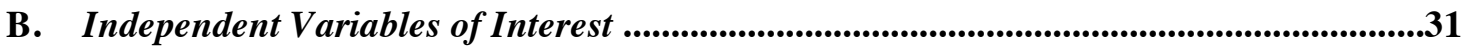

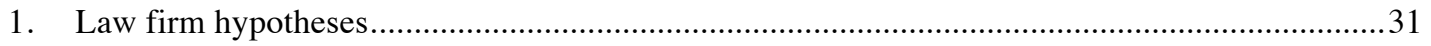

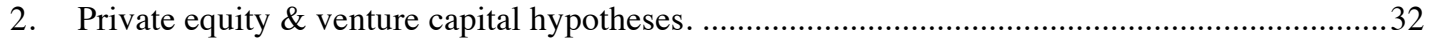

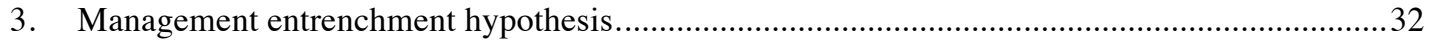

C. Other Explanatory and Control Variables ..............................................................33

D. Description of Empirical Sample .........................................................................................34

D. Qualitative Data ................................................................................................................35

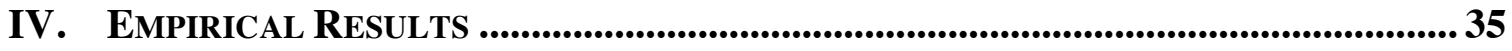

A. Descriptive Data .....................................................................................................35

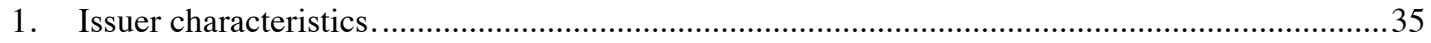

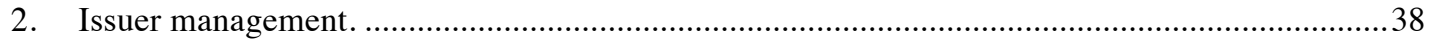

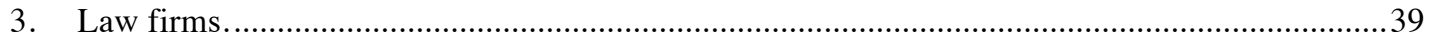

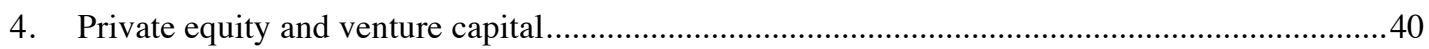

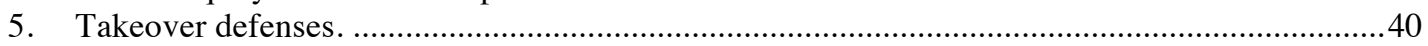

B. Mean Comparisons and Univariate Regressions ..........................................................44

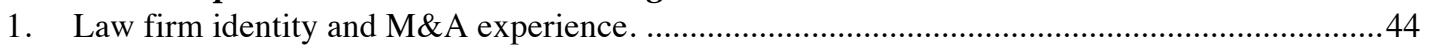

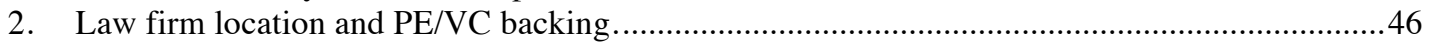

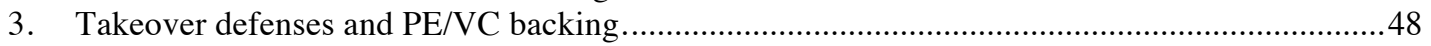

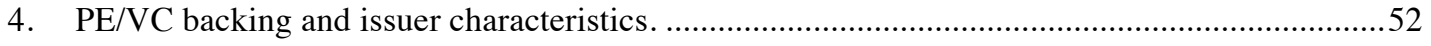

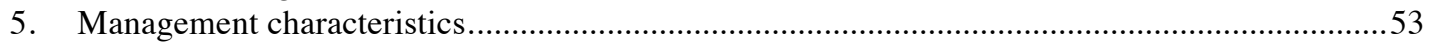

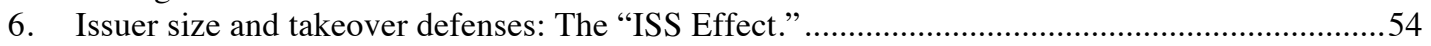

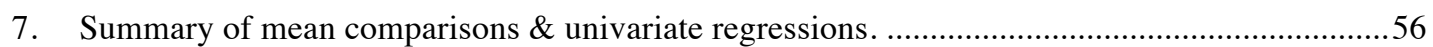

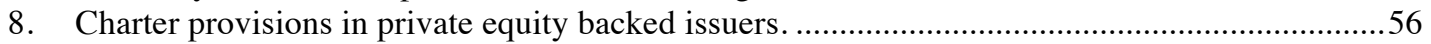

9. Mutual funds and pension funds as pre-IPO shareholders. .......................................................57

C. Multivariate Regressions and Analysis ....................................................................................59

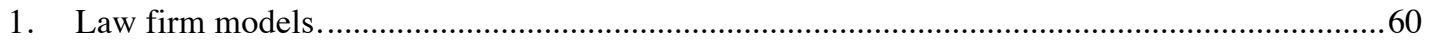

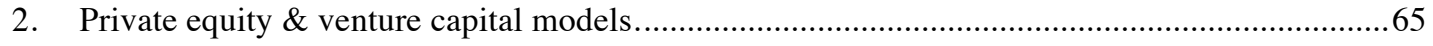

3. Management entrenchment models........................................................................................

4. Comprehensive models and dual class control model.................................................................. 74

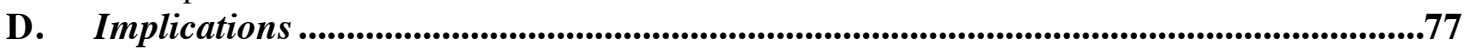

1. Institutional investors should exercise their influence over general partners and reevaluate the

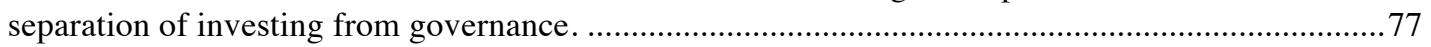

2. Staggered boards should have sunset provisions................................................................. 78

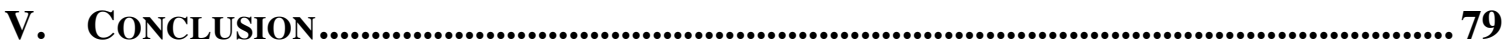




\section{INDEX OF TABLES AND FigURES}

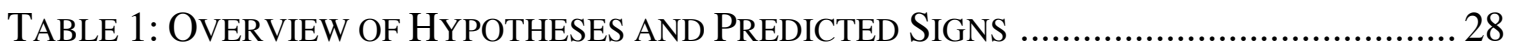

TABLE 2: SUMMARY STATISTICS FOR THE COMPLETE SAMPLE ………………………........... 37

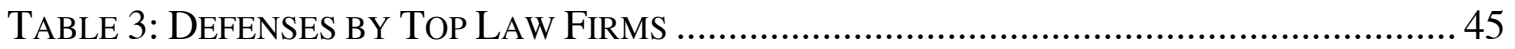

TABLE 4: ESB INCIDENCE BY LAW FIRM'S M\&A ROLE .................................................. 46

TABLE 5: ESB INCIDENCE BY NEW YoRK LAW FIRMS \& PE BACKING .............................. 46

TABLE 6: ESB INCIDENCE By SiLICON VALLEY LaW FIRMS AND VC BACKING.................. 48

TABLE 7: TAKeOVER DEFENSE FReQUENCY WITH VC \& PE SubSAMPLES ........................... 49

TABLE 8: ESB INCIDENCE BY VC \& PE BACKING ………….......................................... 50

TABLE 9: SUMMARY STATISTICS FOR VC AND PE-BACKED ISSUER SUBSAMPLES .............. 53

TABLE 10: ESB INCIDENCE BY CEO CHARACTERISTICS ................................................ 54

Table 11: TaKeover Defenses in Mutual and Pension Fund BaCKed IPOs ............. 58

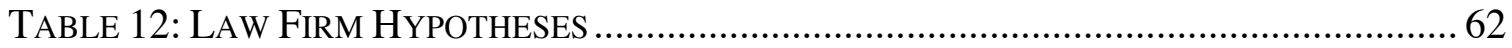

TABle 13: Private Equity \& Venture CaPiTAL HypotheSeS ......................................... 66

TABLE 14: MANAGEMENT ENTRENCHMENT HYPOTHESIS ................................................... 72

TABle 15: Comprehensive \& Dual Class Control Models ......................................... 75

FIGURE 1: LIMITED PARTNERS BY INVESTOR TYPE ………........................................... 19

Figure 2: Dual Class Structures by Year ............................................................ 41

FigURE 3: PERCENTAGE OF IPOS WITH ClasSIFIED BoARDS ............................................ 43

FigURE 4: ClASSIFIED BOARD INCIDENCE BY VC AND PE BACKING …………….............50

FIGURE 5: CLASSIFIED BOARD INCIDENCE IN IPOS AND STOCK INDICES ............................ 55

FigURE 6: CLASSIFIED BOARD INCIDENCE IN IPOS MATCHED TO COMPARABLY SIZED

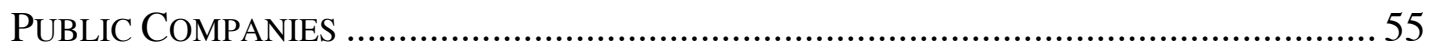





\section{INTRODUCTION}

Over thirty years after the poison pill was first invented, the fight over takeover defenses still figures prominently in public discourse on corporate governance and shareholder rights. ${ }^{\dagger}$ While courts have generally decided in favor of boards, ${ }^{\dagger}$ shareholder activists have been extremely successful at the ballot box. ${ }^{\S}$ Over the past decade, virtually every major mutual fund and public pension fund has come out in opposition to takeover defenses such as staggered boards in public companies. This public pressure, often expressed through shareholder proposals, has resulted in a massive trend towards board declassification in public companies.

Despite all of this public opposition to certain takeover defenses, a majority of companies continue to go public with staggered boards in place. In this Article, I investigate the determinants of whether or not companies have takeover defenses such as an effective staggered board in place at the time of their initial public offerings. First, I describe and examine various law firm hypotheses. I test the hypothesis that the quality of legal services - as measured by a law firm's overall experience in public M\&A transactions-provided to pre-IPO manager-shareholders explains the variation in the adoption of takeover defenses at the IPO. Alternatively, I examine whether the type of M\&A experience, i.e. a law firm's experience representing acquirers or targets, is responsible for the variation, as the perceived value of defenses to lawyers may depend on the role the law firm typically plays in M\&A transactions. I also examine whether the location of the law firm affects whether a law firm installs takeover defenses in IPO firms.

Second, I examine the relationship between the type of an issuer's pre-IPO shareholders and the presence of takeover defenses at IPOs. Because the most ardent opponents of takeover defenses in public companies are mutual funds and institutional investors that invest in private equity and venture capital funds, the institutional investor efficiency hypothesis predicts that companies backed by private equity or venture capital funds are less likely to go public with takeover defenses than other firms. Contrarily, private equity and venture capital firms may find IPO takeover defenses optimal because they may allow them to maintain outsize influence on companies once they go public. It is also possible that private equity and venture funds may discipline management and

\footnotetext{
${ }^{\dagger}$ E.g., Alison Frankel, Columbia professor defends Harvard Law from Wachtell attack, THOMsON REUTERS, April 3, 2012, http://newsandinsight.thomsonreuters.com/Legal/News/2012/04__April/Columbia_professor_defends_Harvard_Law_from_Wachtell_attack/.

¥See Air Products \& Chemicals, Inc. v. Airgas, Inc., 16 A.3d 48, 153 (Del. Ch. 2011) (upholding a staggered board's discretion to maintain a poison pill even after losing an election to a hostile bidder).

$\$$ Georgeson, 2012 AnNual Corporate Governance Review 6-7 (2013), http://www.georgeson.com/us/resource/Pages/acgr.aspx (detailing the support for shareholder proposals to declassify boards).
} 
serve as substitutes for the external market for corporate control and, therefore, their presence as pre-IPO shareholders may not affect the adoption of takeover defenses. Finally, the management entrenchment hypothesis predicts that pre-IPO managershareholders may find that IPO takeover defenses are optimal in order to protect their non-pecuniary benefits of control.

I rely on a sample of 259 initial public offerings for U.S. companies from 2008 to 2012, public positions and proxy voting policies published by institutional investors, and numerous interviews with partners and principals at law firms, venture capital firms, and private equity firms in order to investigate the law firm hypotheses, pre-IPO shareholder hypotheses, and management entrenchment hypothesis. As a preliminary matter, I find that the percentage of companies that go public with a classified board is significantly higher than the percentage of similarly sized public companies that have classified boards.

First, I find strong empirical evidence that the identity of an issuer's law firm and the firm's role in public M\&A transactions affects whether the issuer goes public with an effective staggered board. Issuers using law firms that predominantly represented M\&A targets were more likely to go public with a classified board, while acquirer-side M\&A experience was correlated with a lower likelihood of takeover defense adoption. The contrast between two very different law firms-Wilson Sonsini and Simpson Thacheris particularly illustrative. Wilson Sonsini, a Palo Alto-based law firm famous for representing venture-backed companies and which primarily represents M\&A targets, is installing staggered boards at $100 \%$ of its clients while Simpson Thacher, a New York law firm that is well-known for its private equity practice and its representation of M\&A acquirers, only installs staggered boards at $50 \%$ of its IPO clients. These findings stand in stark contrast from the findings of a previous study by Professor John Coates, in which Wilson Sonsini was found to never install classified boards in the early 1990s while New York law firms were much more likely to install such defenses in IPO companies.

Second, the presence of a venture capital fund amongst an issuer's pre-IPO shareholders is correlated with a significantly higher likelihood that an issuer goes public with an effective staggered board. On the other hand, the presence of a private equity fund has no statistically significant relationship with the adoption of a staggered board and decreases the likelihood that a company goes public with dual class control structure. These results are particularly interesting because there is significant overlap in the identity of limited partners in private equity and venture capital funds, and many of these limited partners zealously oppose takeover defenses in public companies. Additionally, I find that issuers in which mutual and pension funds are significant pre-IPO shareholders almost always go public with the strongest takeover defenses despite the fact that these shareholders have publicly adopted positions that ardently oppose these defenses. Lastly, 
there is not sufficient evidence to conclude that pre-IPO shareholder-managers take companies public with takeover defenses in order to protect their private benefits of control.

The fact that the two most prominent types of financial sponsors in the IPO market-private equity funds and venture capital funds-install such defenses at significantly different rates provides evidence that it is not generally optimal for companies to go public with takeover defenses. The lack of a consensus amongst the law firms with the most experience regarding takeover defenses adds further support for this conclusion. I conclude this Article by calling attention to two implications of my findings. First, I suggest that institutional investors and mutual funds need to investigate their inconsistent behavior with respect to takeover defenses. If they truly believe in their publicly adopted corporate governance policies and wish to serve as stewards as good governance, they need to make sure that their investment decisions are consistent with their positions. Finally, I note that the governance arrangements that may be optimal for companies at their IPOs may not be optimal later in their public lives. Therefore, I suggest that companies that wish to go public with defenses such as staggered boards should install automatic sunset provisions for these defenses in order to maximize value.

The remainder of the paper is organized as follows. Part II begins with a discussion of the market for corporate control and provides a brief overview of takeover defenses. I then review and propose theories to explain the variation in takeover defenses at IPO companies. Part III describes the sample and details the variables that I examine. Part IV presents the results of the empirical tests used to test the competing theories and my interpretations of the empirical and qualitative data. Part V presents my conclusion.

\section{TAKeOVER Defenses In PUBlic COMPANIES}

\section{A. The Market for Corporate Control and Takeover Defenses at Public Companies}

In a groundbreaking article in 1965, Henry Manne famously introduced the "market for corporate control" and explained how it serves as a disciplining force on public company management by pressuring them to perform, or else risk the sale of the company to somebody who will do a better job.* Manne succinctly described the forces at work:

The lower the stock price, relative to what it could be with more efficient management, the more attractive the take-over becomes to those who

\footnotetext{
** See generally Henry G. Manne, Mergers and the Market for Corporate Control, 73 J. POL. ECON. 110 (1965).
} 
believe that they can manage the company more efficiently. And the potential return from the successful take-over and revitalization of a poorly run company can be enormous. . . . Only the take-over scheme provides some assurance of competitive efficiency among corporate managers and thereby affords strong protection to the interests of vast numbers of small, non-controlling shareholders. ${ }^{\dagger \dagger}$

Manne, however, also noted that the disciplinary force of the market for corporate control weakens when transaction costs, legal barriers, and practical barriers increase. ${ }^{\ddagger}$ In today's market, the most prominent barrier comes in the form of takeover defenses that insulate management from the market.

In an effort to fend off coercive bust-up takeovers and threats of greenmail by corporate raiders in the early 1980s, corporate lawyer Martin Lipton of Wachtell, Lipton, Rosen \& Katz ("Wachtell Lipton") introduced a potent defense that drastically changed the landscape of the takeover universe: the shareholder rights plan, commonly referred to as a "poison pill." As a result of the Delaware Supreme Court's decision upholding the legality of the pill in Moran v. Household International,${ }^{\S \S}$ the only practical way for a bidder to obtain control of a company whose board has adopted and maintained a pill is to replace the company's board with one that will redeem the pill. ${ }^{* * *}$ If the entire board is up for election on an annual basis, then the bidder can simply run a proxy contest at the next annual meeting to replace the board and have the pill redeemed. ${ }^{\dagger \dagger}$ However, when a poison pill is combined with a classified board, the target board can maintain a pill even after losing a proxy contest to the hostile bidder.

\section{Overview of classified boards and takeover defenses.}

Corporate law vests the power to manage the corporation in its board of directors. Directors have traditionally been given substantial flexibility, subject to fiduciary duties, to pursue their vision of what they believe is best for the corporation and the shareholders

${ }^{\dagger} I d$. at 113 .

\# Id. at 119 .

$\$ 500$ A.2d 1346 (Del. 1985).

*** See id. at 1354. A Delaware court could technically order the board to redeem a pill under Unocal if the board has not fulfilled its fiduciary duties, but courts almost never do so. E.g., Air Products \& Chemicals, Inc. v. Airgas, Inc., 16 A.3d 48, 129 (Del. Ch. 2011) ("The mechanisms in place to get around the poison pill-even a poison pill in combination with a staggered board, which no doubt makes the process prohibitively more difficult - have been in place since 1985, when the Delaware Supreme Court first decided to uphold the pill as a legal defense to an unwanted bid. That is the current state of Delaware law until the Supreme Court changes it.”). But see City Capital Associates Ltd. Partnership v. Interco Inc., 551 A.2d 787, 800 (Del. Ch. 1988) (granting a preliminary injunction ordering a board to redeem a poison pill after finding that it was not proportionate to the threat under Unocal).

${ }^{\dagger \dagger}$ See Leo E. Strine, Jr., One Fundamental Corporate Governance Question We Face: Can Corporations Be Managed for the Long Term Unless Their Powerful Electorates Also Act and Think Long Term, 66 Bus. LAW. 1, 4 (2010). 
they represent. The legitimacy of this directorial power ultimately rests upon the preservation of the shareholder franchise. As noted by Chancellor Strine of the Delaware Court of Chancery, shareholders have an especially legitimate interest in having a regular opportunity to elect a new board when directors have the authority to use takeover defenses that insulate the company from the market for corporate control. ${ }^{\S \S}$

Under the default law in almost every state, all directors stand for election at each annual meeting. ${ }^{* * * *}$ However, all states also provide an exemption from this requirement if the company elects to have a staggered, or classified, board. ${ }^{\dagger+1}$ In a company with a staggered board, directors are grouped into separate classes. Only one class will stand for election at each annual meeting, and it will be elected for a term of years equal to the number of classes. ${ }^{* t}$ The most common (and in many states such as Delaware, maximum) number of classes is three. For example, a board of nine directors would be split into three equal classes, each consisting of three directors. The three directors of Class I may stand for election for a three-year term at the 2014 annual meeting. Class II would stand for (re)election at the 2015 annual meeting while the three directors of Class III would stand for (re)election at the 2016 annual meeting.

Because only one third of the board is up for election at each annual meeting at a company with a three-class staggered board, a bidder-no matter how attractive his offer-may have to win two successive elections in order to replace a majority of the board and redeem a poison pill. This insulates management from and weakens the benefits provided by the market for corporate control. In fact, the most potent version of a staggered board-an "effective staggered board" ("ESB") - is designed to prevent circumvention so that there is no possible way to replace a majority of the board in less than two annual elections. Professors Lucian Bebchuk, John Coates, and Guhan Subramanian expound upon the remarkable force of the ESB:

There are two reasons why an ESB presents such a serious impediment to a hostile bidder seeking to gain control over the incumbents' objections. First, an ESB substantially increases the delay involved in gaining control

护 Blasius Indus., Inc. v. Atlas Corp., 564 A.2d 651, 658 (Del. Ch. 1988) ("The shareholder franchise is the ideological underpinning upon which the legitimacy of directorial power rests.").

$\S \S$ See Strine, supra note $\uparrow \dagger \dagger$, at 6 .

**** See Lucian Bebchuk, John C. Coates \& Guhan Subramanian, The Powerful Antitakeover Force of Staggered Boards: Theory, Evidence, and Policy, 54 STAN. L. REV. 887, 893 (2002) [hereinafter BCS, Effective Staggered Boards]. The exceptions include Iowa and, until recently, Oklahoma. Iowa amended its laws to provide for mandatory staggered boards until at least December 2014. IA. BUS. CORP. ACT $\S$ 490.806A (West 2013). In late 2010, Oklahoma required publicly traded companies to adopt staggered boards. OKLA. STAT. AnN.tit. 18, § 1027(D). In March 2013, however, the legislature reversed course and changed the default law back to annual elections. Oklahoma General Corporation Act, 2013 Okla. Sess. Law Serv. ch. 1 (H.B. 1646) (West).

${ }_{\dagger+\dagger}$ E.g., MOdEL BuS. CORP. ACT. $\$$ 8.06; CAL. Corp. CODE $§ 301.5$.

㧊 Id. 
of the board and, importantly, establishes a large minimum delay. No matter when a hostile bidder emerges, gaining control of the board would take at least one year, a very long time indeed in the dynamic world of corporate acquisitions. Second, beyond the costs imposed by delay, to overcome an ESB a bidder must win two elections, far apart in time, rather than one up-or-down referendum conducted at a single point in time. [T] he two-election problem is a serious one that, combined with the delay problem, makes an ESB a powerful, even if not insurmountable, antitakeover device. Indeed, . . . an ESB provides managers with stronger protection from a hostile takeover than would an arrangement (not currently permitted under Delaware law) providing directors with guaranteed three-year terms. ${ }^{\S \S \S}$

Arguments on the merits of takeover defenses such as classified boards have been put forward in dozens of empirical studies, law review articles, and law firm memos and are synthesized in other works. ${ }^{* * * *}$ Proponents have argued that classified boards help companies fend off inadequate takeover bids, ${ }^{\dagger \dagger \dagger \dagger}$ are necessary for increased board stability, and promote longer-term strategic thinking. ${ }^{* * *}$ Numerous empirical studies have rejected such claims. ${ }^{\S \S \S \S}$ Field and Karpoff found that firms with takeover defenses are less likely to be acquired and that managers can use defenses to protect their private benefits of control at the expense of outside shareholders such as institutional investors. ${ }^{* * * * * *}$ On the other hand, Bates et al. found that the presence of a classified board might increase the proportion of total surplus that target shareholders receive in an

$\S \S \S \S$ BCS, Effective Staggered Boards, supra note ****, at 890.

${ }^{* * * * *}$ For an overview of some of the most convincing arguments and literature, see Coates, infra note $\uparrow+\uparrow+\uparrow+\uparrow+\uparrow+\uparrow+\uparrow \dagger \dagger$, at Part III.

${ }_{\dagger \dagger \dagger \dagger}$ Michael J. Merced, Wachtell Defends Staggered Boards, N.Y. TIMES DEALBoOK, March 21, 2012, http://dealbook.nytimes.com/2012/03/21/wachtell-defends-staggered-boards/ (quoting a Wachtell Lipton client memo).

Powerpoint: Wachtell Lipton Rosen \& Katz, Corporate Governance 21 (Dec. 2012), available at http://www.wlrk.com/files/2012/CorporateGovernanceDecember2012.pdf.

\$§§§ See, e.g., Olubunmi Faleye, Classified Boards, Stability, and Strategic Risk Taking, 65 FIN. ANALYST J. 54, 63 (2009) (finding that there was no statistically significant difference in continuity rates for independent directors of companies with classified boards as opposed to non-classified boards, and that companies with classified boards invested less in research in development).

${ }^{* * * * * *}$ Laura Field \& Jonathan Karpoff, Takeover Defenses of IPO Firms, 57 J. FIN. 1857, 1873 (2002). 
acquisition. ${ }^{\dagger+t+\dagger}$ However, this surplus is likely offset by the overall reduction in announcement period returns ${ }^{*+1+*}$ and deterrence of takeover bids in the first place. ${ }^{\S \S \S \S \S}$

In one of the most influential studies on the topic, Lucian Bebchuk and Alma Cohen examined the relationship between the presence of a classified board and a company's Tobin's Q, a proxy for firm value. ${ }^{* * * * * *}$ They found that board classification was associated with a decrease in firm value. The results were both statistically significant and economically meaningful. ${ }^{+t^{+1+\dagger}}$ However, when separating charter-based and bylaws-based staggered boards in their dataset, Bebchuk and Cohen found that only charter-based staggered boards had a statistically significant negative correlation with firm value. Unlike amendments to the corporate charter, bylaw amendments need not be initiated by or approved by the board of a corporation under the Delaware Code and the Model Business Corporation Act. ${ }^{\S \S \S \S \S}$ A motivated hostile acquirer equipped with knowledgeable legal counsel could amend the bylaws to eliminate the staggered board, rendering the classification illusory.

Bebchuk, Coates, and Subramanian expanded on this analysis and introduced the concept of an effective staggered board, a staggered board that is "appropriately designed to prevent circumvention" by a hostile bidder who does not want to go through two elections. ${ }^{* * * * * * *}$ Therefore, the presence of an ESB is a much more meaningful variable than mere board classification. A staggered board may be labeled as an ESB if it is installed in the charter, ${ }^{,+t+1+t \dagger}$ directors may only be removed for cause, ${ }^{+\cdots+\cdots+\cdots}$ and

${ }^{\dagger+1+\dagger \dagger}$ Thomas Bates et al., Board Classification and Managerial Entrenchment: Evidence from the Market for Corporate Control, 87 J. FIN. ECON. 656, 669 (2008) (finding that "board classification by targets is associated with a larger proportional distribution of total bid surplus for target shareholders relative to the distributions that obtain for targets represented by a single class of directors," but cautioning "against a strong interpretation of this result").

${ }^{+1+*}$ Ronald Masulis et al., Corporate Governance and Acquirer Returns, 62 J. FIN. 1851, 1875 (2007). The authors found a statistically significant decrease in the bidder's 5-day cumulative abnormal returns when a target had classified board. They also found a statistically significant decrease for each marginal addition of a takeover defense in the E-Index, as well as the Gompers 24-variable IRRC index.

$\S \S \S \S \S$ Bates et al., supra note $\uparrow \uparrow \uparrow \uparrow \uparrow \dagger$, at 671 (finding that companies with a classified board were $0.5 \%$ less likely to receive a takeover bid).

${ }^{* * * * * * *}$ Lucian A. Bebchuk \& Alma Cohen, The Costs of Entrenched Boards, 78 J. FIN. ECON. 409, 423 (2005). Q is equal to the market value of assets divided by the book value of assets. Bebchuk, Cohen, and Allen Ferrell later on expanded this study by analyzing what other antitakeover provisions had a negative relationship with Tobin's Q and came up with a 6-variable Entrenchment Index ("E-Index"). See generally Lucian A. Bebchuk, Alma Cohen, \& Allen Ferrell, What Matters in Corporate Governance?, 22 REV. FIN. STUD. 783 (2009).

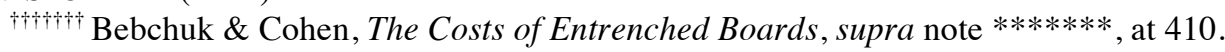

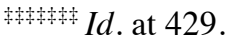

$\S \S \S \S \S \S$ See, e.g., Del. CODE. ANN. tit. 8, §109; Model Bus. CORP. ACT § 10.20; N.Y. Bus. CORP. LAW $\S 601$.

********B BCS, Effective Staggered Boards, supra note ****, at 890.

$+\dagger+1+1 \dagger \dagger$ One needs the approval of both shareholders and the board in order to remove a staggered board that is installed in the charter. DEL. CODE. ANN. tit. 8, §242. Alternatively, if a staggered board is 
shareholders cannot "pack the board" by increasing the number of directors and filling

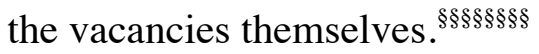

Bebchuk, Coates, and Subramanian found that firms with an ESB did not receive a statistically significant different bid premium, on average, than firms without an ESB. ${ }^{* * * * * * * *}$ Underscoring the deterrent effect of an ESB, they found that an ESB doubled the likelihood that a target would remain independent following a bid and cuts the odds of the target being taken over by the first bid in half. ${ }^{+t+t+t+1}$ They conclude that shareholders of companies that used their ESBs to fend off acquirers were made worse off than if those companies accepted the hostile bids. ${ }^{+1+1+1+}$ A more recent event study by Guo, Kruse, and Nohel examined the stock market reaction to public company announcements of management plans to eliminate staggered boards. They found that shareholders experienced statistically significant positive abnormal returns when portfolio companies revealed immediate plans to switch to annual elections..$^{\S \S \S \S \S \S \S \S}$ These results provide persuasive evidence that staggered boards destroy may value in public companies by insulating management from the market for corporate control.

\section{Opposition to takeover defenses at public companies.}

While there may not be a unanimous academic consensus, institutional investors' omnipotent opposition to takeover defenses at public companies indicates that there is a consensus in the investor community regarding the inefficiency of takeover. Institutional investors have largely opposed the adoption or bolstering of takeover defenses at public companies. $^{* * * * * * * * *}$ In fact, many have adopted and recommended guidelines to automatically oppose such amendments. ${ }^{\dagger+t+1+t \dagger}$ All of the five largest U.S. mutual

located in the bylaws and a supermajority of the vote is required to amend the bylaw, it may be classified as an ESB.

Directors of companies incorporated in Delaware may only be removed for cause unless the charter explicitly allows for removal without cause. DEL. CODE. ANN. tit. 8, §109(k).

$\S \S \$ \S \S \S \S$ BCS, Effective Staggered Boards, supra note ****, at 894.

at 936 .

Bebchuk, Cohen \& Ferrell, What Matters in Corporate Governance, supra note *******,

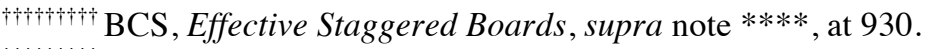

+ $1 d$. at 934-35.

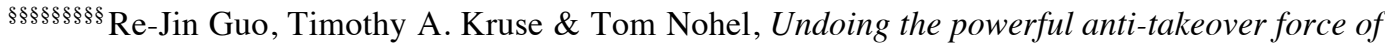
staggered boards, 14 J. CORP. FIN. 274, 287 (2008).

*********** See, e.g., WILMERHALE, 2010 IPO REPORT 12 (2010), available at http://www.wilmerhale.com/files/upload/IPO_report_2010.pdf; Bates et al., supra note $\dagger+\dagger+\dagger \dagger$, at 669 ("[in] 2005 more than 65 firms had a repeal [of classified boards] proposed in the annual proxy, while the proportion of firms covered by ISS with classified boards declined from $55.10 \%$ in 2003 to $52.60 \%$ in 2005”); Michael Klausner, Institutional Shareholders, Private Equity, and Antitakeover Protection at the IPO Stage, 152 U. PA. L. REV. 755, 755, 759 (2003).

Robert Daines \& Michael Klausner, Do IPO Charters Maximize Firm Value? Antitakeover Protection in IPOs, 17 J. L. ECON. \& ORG. 83, 87 (2001). 


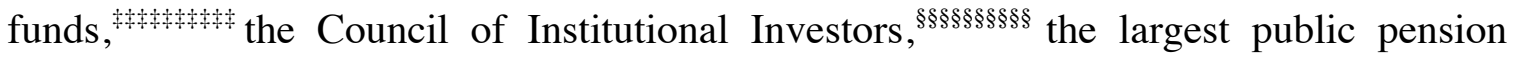

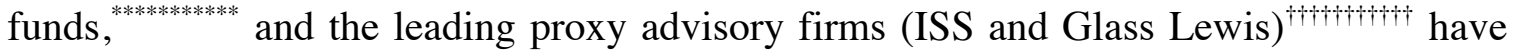
adopted policies that support the annual election of directors and oppose board classification. The Ontario Teachers' Pension Plan - which manages over $\$ 117$ billion in assets - recently summarized several reasons why it opposes staggered boards:

We see many disadvantages with a classified system. Staggered terms for board member make it more problematic for shareholders to make fundamental changes to the composition and behaviour of boards, by making it extremely difficult for any challenge to, or change in, board control. In circumstances of deteriorating corporate performance, this difficulty could result in a permanent impairment of long-term

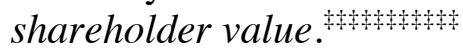

Many public companies - especially the largest ones-have chosen to declassify their boards in response widespread opposition. From 2000 to 2009, the number of S\&P 500 companies with staggered boards declined by more than $40 \% .8 \$ \$ \$ \$ \$ \$ s \S ~ I n$ the 2012 proxy season alone, Harvard's Shareholder Rights Project (“SRP”) ${ }^{* * * * * * * * * * *}$ submitted 90

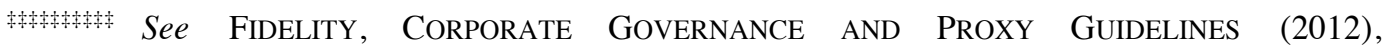
http://personal.fidelity.com/myfidelity/InsideFidelity/InvestExpertise/governance.shtml; $\quad$ VANGUARD, UPDATE ON PROXY VOTING-JUNE 2012 (2012), https:/investor.vanguard.com/about/update-on-proxyvoting-june-30-2012; AMERICAN FundS, Proxy Voting Procedures AND PRinCiPles 3 (2012), https://www.americanfunds.com/pdf/proxy_voting_guidelines.pdf; FRANKLIN MUTUAL ADVISERS, PROXY $\begin{array}{llllll}\text { VOTING POLICIES } & \& & \text { PROCEDURES } & 5 & \text { (2013), }\end{array}$ https://www.franklintempleton.com/retail/pdf/proxies/FMA_ProxyVotingPolicies.pdf; T. RowE PRICE, PROXY VOTING POLICIES (2012), http://corporate.troweprice.com/ccw/home/socialResponsibility/conductingBusinessResponsibly/proxyVoti ngPolicies.do. In fact, all of the top twenty-five mutual fund families (by assets under management) have adopted policies that oppose an effective staggered board.

$\$ \$ \$ \& \& \$ \$ \&$ COUNCIL OF INSTITUTIONAL INVESTORS, POLICES ON CORPORATE GOVERNANCE (2012), http://www.cii.org/corp_gov_policies\#BOD.

${ }^{* * * * * * * * * * *}$ For example, the California Public Employees' Retirement System (CalPERS), the largest public pension fund in the U.S., calls for annual director elections in its corporate governance principles for proxy votes. CALPERS, Global PRinCIPLES OF ACCOUNTABLE CORPORATE GOVERNANCE 17 (2010), http://www.calpers-governance.org/docs-sof/principles/2010-5-2-global-principles-ofaccountable-corp-gov.pdf.

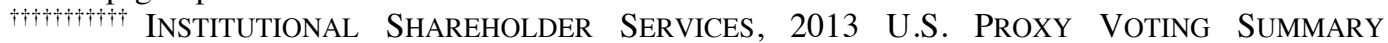
GUIDELINES (2013), http://www.issgovernance.com/files/2013ISSUSSummaryGuidelines1312013.pdf; Glass LEWIS \& CO., PROXY PAPER GuIDELINES (2013), http://glasslewis.com/assets/uploads/2012/02/Guidelines_UnitedStates_2013_Abridged.pdf.

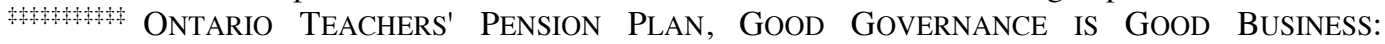
Corporate Governance Principles ANd Proxy Voting Guidelines 26 (2013) (emphasis added), http://www.otpp.com/documents/10179/20940/TeachersCorpGovE.pdf/cfca9682-9368-4cf4-96cefe5381d5647e.

$\$ \$ \$ s \$ 8 \$ s \$ 8$ Lucian A. Bebchuk, Alma Cohen \& Charles C.Y. Wang, Staggered Boards and the Wealth of Shareholders: Evidence from Two Natural Experiments 2 (Harvard Law \& Econ., Discussion Paper No. 697, 2011), available at http://ssrn.com/abstract=1706806.

************Harvard's Shareholder Rights Project is a clinical program at Harvard Law School directed by Professor Lucian A. Bebchuk. Shareholder Rights Project, HARVARD Law SchOOL, http://srp.law.harvard.edu/. 
shareholder proposals on behalf of six public pension funds calling for boards to switch to annual elections. In its first year, SRP successfully declassified the boards of one-third of the S\&P 500 companies that had staggered boards. ${ }^{\text {titititit }}$ The subsequent management declassification proposals received an average of 99 percent of votes cast, ${ }^{+\infty+1+1+1}$ revealing investors' robust opposition to classified boards.

\section{B. Theories on the Determinants in Takeover Defenses at IPO Firms}

The robust academic and nearly unanimous investor opposition to defenses in public companies provides convincing support to the theory that takeover defenses are inefficient and destroy shareholder value in public companies. Surprisingly, however, a

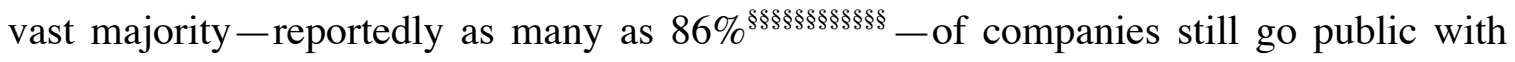
staggered boards. In today's market, where it has become nearly impossible to adopt takeover defenses that require shareholder approval in public companies, ${ }^{* * * * * * * * * * * *}$ a firm's selection of takeover defenses and board structure at its IPO is a critical decision. Nevertheless, as companies are generally believed to attempt to maximize their value when they go public, one would expect issuers to go public without takeover defenses that are widely said to destroy value. In order to explain this puzzle, I explore how the issuer's choice of law firm, the type of pre-IPO shareholders, and indicia of management's private benefits of control may affect an issuer's decision to go public with takeover defenses that insulate the issuer from the market for corporate control.

\section{Law firm effects on IPO takeover defenses.}

A little-discussed but tremendously important determinant of the variation of takeover defenses is the legal services provided to pre-IPO shareholder managers. In a 1984 article, Gilson aptly described corporate lawyers serve as "transaction cost engineers." corporate lawyers have become the primary players in many types of

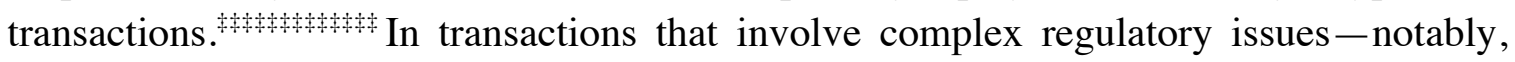
IPOs - lawyers play a critical role in designing the transaction structure in order to attain

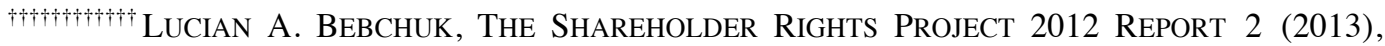
available at http://srp.law.harvard.edu/releases/SRP-2012-Annual-Report.pdf.

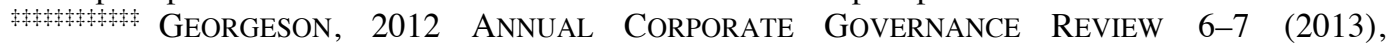
http://www.georgeson.com/us/resource/Pages/acgr.aspx.

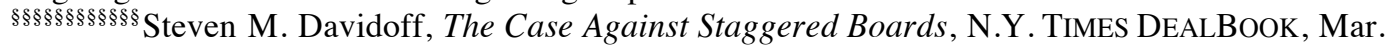
20 2012, http://dealbook.nytimes.com/2012/03/20/the-case-against-staggered-boards/.

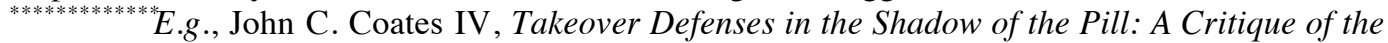
Scientific Evidence, 79 TEX. L. REV. 271, 323-25 \& n.209 (2000); Gerald Davis \& Tracy Thompson, A Social Movement Perspective on Corporate Control, 39 ADMIN. SCI. Q. 141 (1994).

${ }_{\dagger+\dagger+\dagger+\dagger+\dagger \dagger \dagger}$ Ronald Gilson, Value Creation by Business Lawyers, 94 YALE L.J. 293, 310 (1984).

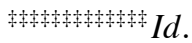


the desired regulatory treatment..$^{\S \S \S \S \S \S \S \S \S \S}$ Gilson therefore hypothesized, "economies of scope should cause the non-regulatory aspects of transactional structuring to gravitate to the lawyer as well." ${ }^{, * * * * * * * * * * * * * *}$ Later, Dent built upon Gilson's analysis and argued that it

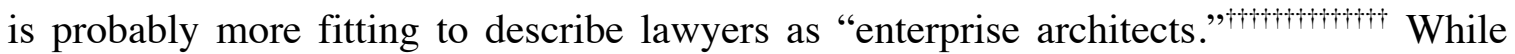
the client of a corporate lawyer is supposed to be the corporation, in transactions such as IPOs, the lawyer often works for multiple parties with divergent interests. The lawyer may directly work with the managers, the board of directors, and sophisticated pre-IPO shareholders such as venture capital and private equity funds. However, the lawyers also have to weigh the effects of their work on the corporate entity itself and outside shareholders who they likely have never met. Additionally, in complex transactions that are not negotiated at arms length, opportunism is a significant issue. ${ }^{.+1+1+0+1+1 \neq}$ Therefore, corporate lawyers need technical skills in "enterprise design"-creating the best entity

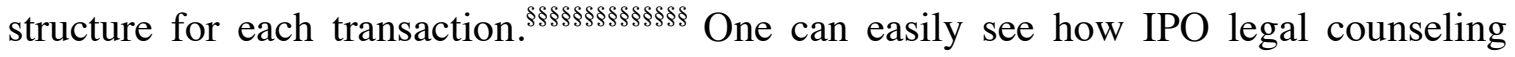
brings the concept of lawyers as "enterprise architects" to life. After all, lawyers prepare the registration statement and author the documents - charters and bylaws - that contain takeover defenses.

This lays the basis for a potential agency problem: the agency costs between preIPO shareholders and their lawyers. ${ }^{* * * * * * * * * * * * * * * *}$ Managers (principals), who often have little-to-no experience in IPOs, rely on their lawyers (agents) to provide advice about the corporate structure, takeover defenses, and their implementation. In the seminal paper on this topic, Coates suggests that most clients are ill-equipped to monitor implementation and have little information about the effects of their lawyers' actions, which may not manifest until years down the road. ${ }^{+1+t+1+t+1+t+\dagger}$ As it takes substantial effort for lawyers to gain proficiency in advising about and implementing takeover defenses, Coates suggested "lawyers will only undertake the minimal level of effort that an be easily monitored by clients." form of reduced IPO proceeds and a lower subsequent market value for their

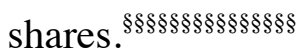

§§§§§§§§§§§§ See id. at 353.

***************1d.

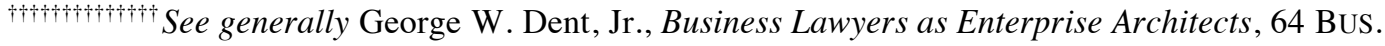
LAW. 279 (2009).

+中+क

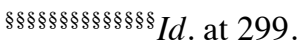

****************⿲二丨匕

REV. 713, 736 (2003).

 89 CAL. L. REV. 1301, 1357 (2001) [hereinafter Coates, Blame the Lawyers].

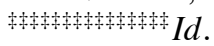

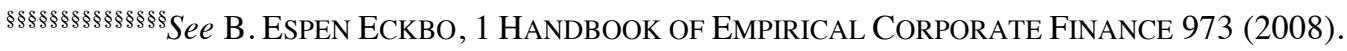


Coates suggested that the quality of legal services provided to IPO companies varies significantly, depending on the experience, size, and location of the law firm that serves as IPO counsel. ${ }^{* * * * * * * * * * * * * * *} \mathrm{He}$ found strong support for the proposition that a firm's array of takeover defenses is determined by lawyers. Specifically, he observed that the overall merger and acquisition ("M\&A") experience, size, and location of law firms strongly correlate with the strength of takeover defenses present at an IPO.

Coates's central hypothesis was that takeover defense adoption should correlate with whether the company's legal counsel has takeover proficiency, measured by the number of M\&A transactions for which the law firm served as primary counsel. ${ }^{\text {for }}$. Wachtell Lipton, did not handle many IPOs and that leading IPO firms, such as Wilson Sonsini, did not handle a high volume of takeovers. ${ }^{\text {} \$ \$ \$ \$ s \S s \S s \S \$ \$ s \S \S}$ Firms with more M\&A experience already have expertise in understanding and implementing takeover defenses and would not need to exert much additional effort in order to give their clients the optimal advice on takeover defenses. Coates therefore hypothesized that if defenses are good for pre-IPO managers, the correlation will be positive; if bad, negative.

Companies advised by larger law firms with more overall M\&A experience were found to adopt more defenses, suggesting that takeover defenses were optimal for pre-IPO managers at the time.

Bebchuk, however, identifies another agency issue that weakens Coates's conclusion about whether takeover defenses are good for pre-IPO shareholders: lawyers' incentives might lead them to prefer the adoption of strong antitakeover protections, whether or not it is in the best interest of pre-IPO shareholders, because lawyers can expect to feel the costs of another arrangement more than its benefits. costs include a greater likelihood that the company will be taken over and the lawyer will lose it as a client, the proposition that managers may blame their lawyers if they find themselves without takeover defenses, and the reputational costs to the lawyers resulting

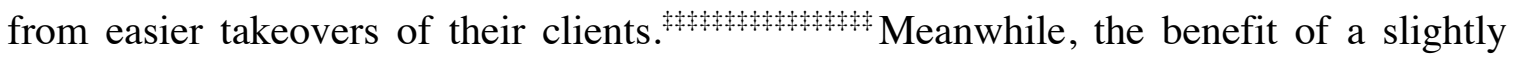

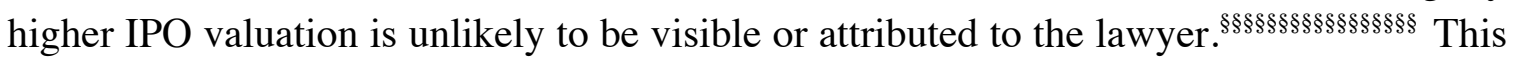
agency problem also leads one to expect that the overall prevalence of takeover defenses

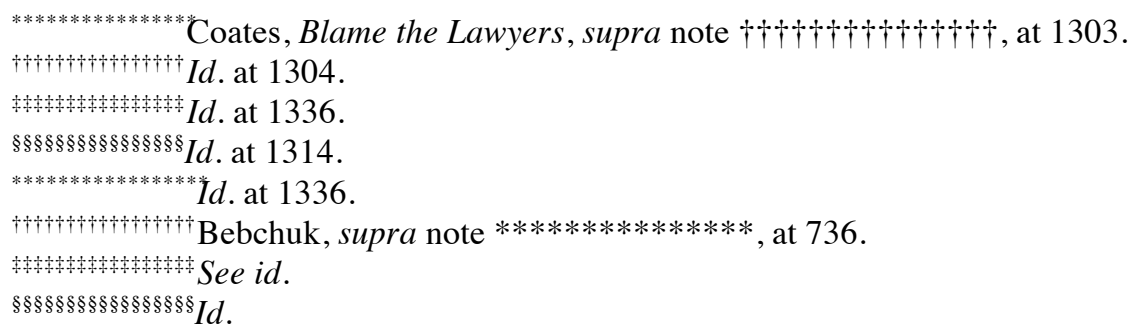


should increase over time as lawyers learn to appreciate their skewed incentives to include more protection.

I refer to this as the "Law Firm M\&A" hypothesis, which predicts that law firms with more M\&A experience-whether they represent targets or acquirers-are more likely to advise companies to adopt strong takeover defenses at their IPOs. Confirmation of this hypothesis will indicate that the law firms that are most knowledgeable about takeover defenses believe that they are optimal. This would not mean that defenses are actually optimal for pre-IPO shareholders. It simply suggests that the most experienced law firms recommend them whether it is because they actually are efficient for the shareholders, or just because the potential loss of a client or reputational harm has led the lawyer to believe they are optimal.

Alternative Hypothesis 1a. The presence of issuer takeover defenses is positively correlated with the issuer's law firm's M\&A experience.

I expect that there is a more nuanced relationship between a law firm's takeover experience and the presence of takeover defenses at IPO companies they advise. Whereas Coates examined overall takeover experience, I focus on the specific role that a law firm actually played in the takeovers where it served as counsel. Recall that Coates observed that the legal market is segmented as some law firms may be more active in the IPO market than in the M\&A market. ${ }^{+1+t+1+t+1+t+1}$ I suggest that there is additional segmentation within the M\&A market - between target and acquirer representation - that can help explain the adoption of defenses. While it is probably somewhat rare for a law firm active in the M\&A market to exclusively represent one or the other, many law firms are known for predominantly representing either acquirers or targets. As takeover defenses are often a useful tool for target-side lawyers in public M\&A transactions, I expect that law firms that represent more targets are more likely to advise issuers to adopt takeover defenses. Across the table, acquirer-side lawyers may believe that takeover defenses complicate their jobs and serve as impediments to transactions.

Under the "Law Firm Role" hypothesis, law firms that represent more targets in M\&A transactions are more likely to advise companies to adopt strong takeover defenses at their IPOs. Law firms that represent more acquirers in M\&A transactions are less likely to adopt defenses. Confirmation of the Law Firm Role hypothesis will, at a minimum, mean that one cannot point to the high incidence of takeover defenses in IPO companies and conclude that defenses are efficient. Instead, confirmation will suggest that there is not an actual client-based reason to use classified boards in IPOs and that their use is explained by the biases of lawyers.

\footnotetext{
*******************see id.

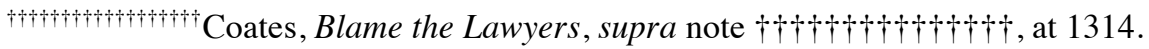


Alternative Hypothesis $\mathbf{1 b}$. Takeover defenses are positively correlated with an issuer's law firm's target-side M\&A experience and negatively correlated with a law firm's acquirer-side $M \& A$ experience.

After hypothesizing that law firms that are physically close to one another are more likely to share information or borrow boilerplate from each other, Coates observed that, in the early 1990s, a company was significantly less likely to have

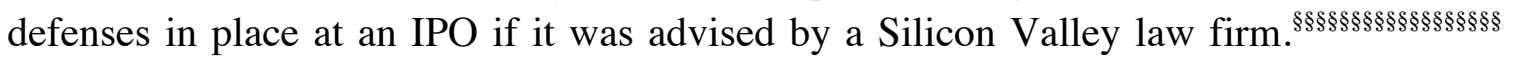
However, this effect dissipated by 1998 , as attention was drawn to this issue and as M\&A knowledge diffused to non-M\&A law firms. It is plausible that Silicon Valley law firms have overcorrected their past failures to understand takeover defenses and now use them in every IPO. Although knowledge about the adoption of defenses may have diffused to non-M\&A law firms over the past two decades, knowledge about the more recent backlash, institutional investor opposition, and empirical studies may not have spread as quickly. The "Silicon Valley Effect" hypothesis therefore predicts that issuers advised by lawyers located in Silicon Valley are more likely to go public with takeover defenses than issuers using law firms located elsewhere.

Hypothesis 2. Issuers' use of takeover defenses will be positively correlated with issuers' use of Silicon Valley law firms.

\section{Institutional investors, financial sponsors, and IPO takeover defenses.}

As private equity and venture capital funds are repeat players in the IPO market and seek to maximize their investment returns, one would expect that almost all IPO firms backed by institutional investors would have annual elections. In a 2003 paper, Michael Klausner summarized why one specifically would expect private equity firms to oppose a portfolio company's inclusion of takeover defenses in charters at the IPO:

The logic, underlying the expectation of takeover-friendly charters at the IPO stage, is strongest for companies with private equity funds as shareholders. Managers of these funds are sophisticated businesspeople who, one would expect, seek to maximize the value of their investments in portfolio companies. They are experienced in corporate governance, they are well positioned to understand the effect of takeover defenses on the value of a firm, and they generally hire sophisticated lawyers to shepherd portfolio companies through the IPO process. Moreover, they play an active, if not dominating, role in managing the companies in their portfolios. It would appear unlikely, therefore, that takeover defenses

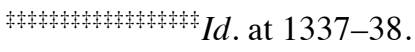

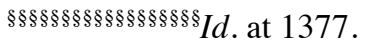


would find their way into the charters of firms in a fund's portfolio."

Indeed, in an earlier study, Daines and Klausner even chose to oversample firms sponsored by institutional investors such as private equity and venture capital firms based on their belief that these firms' incentives to maximize share value would be reflected in

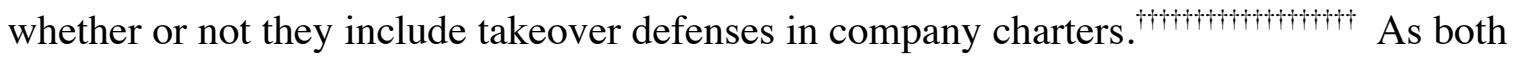
private equity and venture capital funds are of limited duration and often seek to sell their shares rather shortly after an initial public offering, one would expect them to be more concerned with practices that maximize share value instead of private, possibly non-

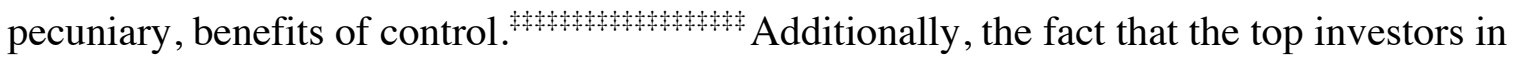

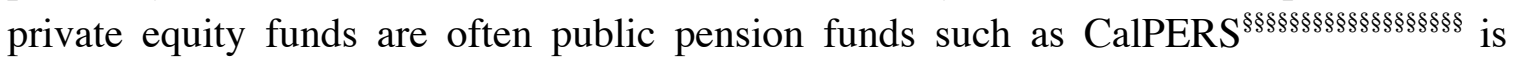
another reason why one would expect IPOs for companies sponsored by private equity funds to go public without classified boards. Past studies, however, have remarkably found no significant difference in the prevalence of takeover defenses such as classified boards based on private equity or venture capital involvement.

Nevertheless, I reexamine this "Institutional Investor Efficiency" hypothesis.

Alternative Hypothesis $3 a$. The presence of private equity, venture capital, or mutual fund backing has a negative correlation with a company's pre-IPO adoption of takeover defenses.

As institutional investors universally oppose takeover defenses in public companies and as institutional investors constitute the majority of the limited partners in private equity and venture capital funds, one can hypothesize that companies backed by institutional investors such as mutual funds, private equity funds, and venture capital funds are less likely to go public with potent takeover defenses than other issuers

\section{a. Overview of private equity and venture capital funds.}

In order to comprehend how private equity and venture capital backing can affect portfolio company governance, one must first understand what private equity and venture capital firms do. Although the line between the two has become increasingly blurred and

*******************\%lausner, supra note $* * * * * * * * * *$, at 769.

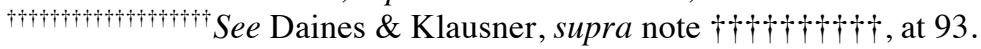

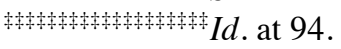

§§§§§§§§§§§§§§§§§§§ See DAVID SNOW, PRIVATE EQUITY: A BRIEF OVERVIEW 7 (2007), http://www.peimedia.com/resources/PEI50/PEI\%20Media's\%20Private\%20Equity\%20-

$\% 20$ A\%20Brief\%200verview.pdf.

*******************E.g., Klausner, supra note $* * * * * * * * * *$, at 769; Daines \& Klausner, supra note $\uparrow+\uparrow+\uparrow+\uparrow \uparrow \dagger$, at 103 ("[i]n all of these regressions, the coefficients on the dummy variables for VC- and LBO-backed firms are insignificant”); Field \& Karpoff, supra note ******, at 1871-72. Additionally, Field and Karpoff found that management compensation is higher in firms with takeover defenses, suggesting that there is not a countervailing tradeoff in compensation. Id. at 1870 . 


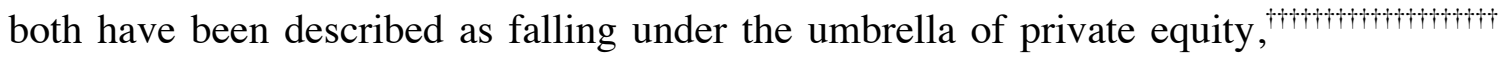
venture capital and private equity have traditionally been considered distinct industries and tend to invest in portfolio companies that are "fundamentally different" from one

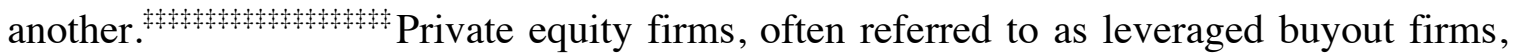
customarily acquire majority control stakes of existing or mature firms with predictable

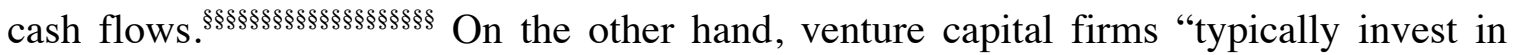
young or emerging companies and typically do not obtain majority control.” ${ }^{, * * * * * * * * * * * * * * * * * * * * * * *}$ Unlike the established companies often found in private equity portfolios, venture-backed companies usually require intensive active involvement from their investors.

Private equity firms (such as Blackstone, The Carlyle Group, and KKR) raise equity capital through private equity funds that they set up. Each fund is usually structured as a limited partnership and has a fixed life of ten to fifteen

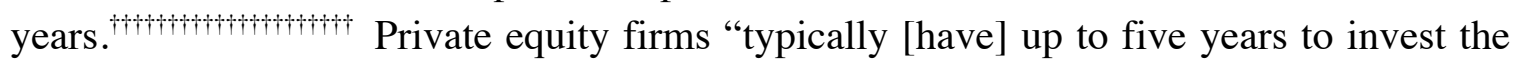
capital committed to the fund into companies, and then [have] an additional five to eight years to return the capital to its investors." for up to three additional years in order to preserve private equity firms'

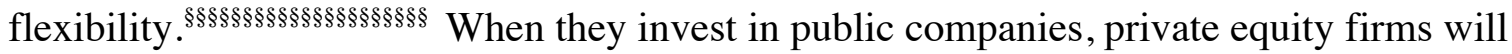
often take the company private in what is known as a buyout, or leveraged buyout ("LBO") if accomplished through the use of debt. More recently, private equity firms have also engaged in "growth equity" investments, where they invest in "rapidly growing companies with proven business models., "*********************** The private equity firm then typically takes on an active role in the management and financing of the acquired company. A private equity firm will often introduce performance-based managerial compensation, highly leveraged capital structures, and active governance to companies in which it invested.

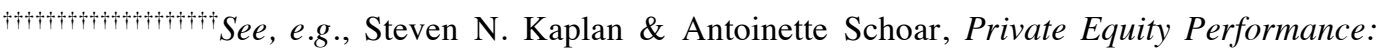
Returns, Persistence, and Capital Flows, 60 J. FIN. 1791, 1791 ("The private equity industry, primarily venture capital (VC) and buyout (LBO) investments, has grown tremendously over the last decade."). $\neq+\neq+\neq+$ Jarrad Harford \& Adam Kolasinski, Do Private Equity Sponsors Sacrifice LongTerm Value for Short-Term Profit? Evidence from a Comprehensive Sample of Large Buyouts and Exit Outcomes 5 (Univ. of Washington Foster Sch. of Bus. Working Paper, 2012) available at http://papers.ssrn.com/sol3/papers.cfm?abstract_id=1785927.

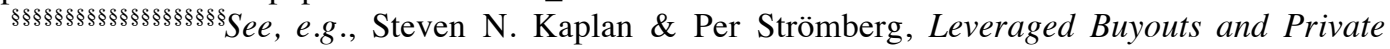
Equity, 22 J. ECON. PERSP. 121, 122 (2008).

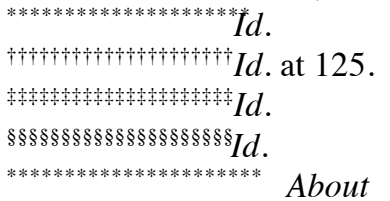

http://www.summitpartners.com/what-is-growth-equity.aspx (last accessed Mar. 29, 2013).

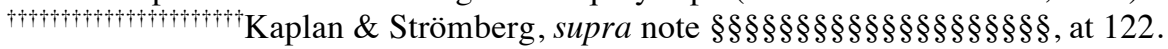


As private equity funds are of a limited duration, a crucial element of the private equity business is the liquidation of a fund's investments in portfolio companies - also known as the exit. A private equity fund usually exits an investment by selling the portfolio company to a strategic buyer, selling the company to another private equity

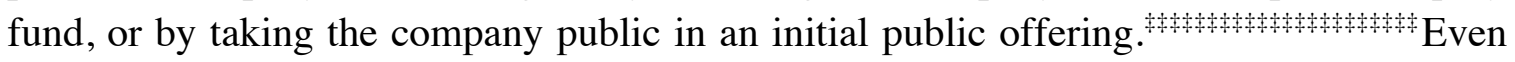
though an initial public offering is one of the least-common exit methods (used in around

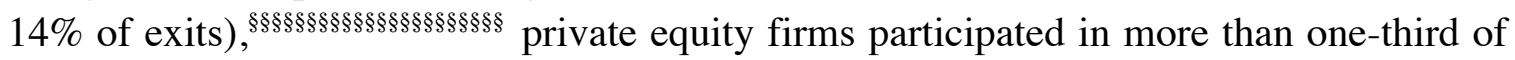
all initial public offerings in the U.S. in recent years. ${ }^{* * * * * * * * * * * * * * * * * * * * * * * * *}$ Once the portfolio company is listed on a public trading market, the private equity funds can gradually sell down their holdings. ${ }^{\mathrm{H}+\mathrm{H}+\mathrm{H}+\mathrm{H}+\mathrm{H}+\mathrm{H}+\mathrm{H}+\mathrm{H}+\mathrm{H}}$ Following an offering, however, a fund can choose

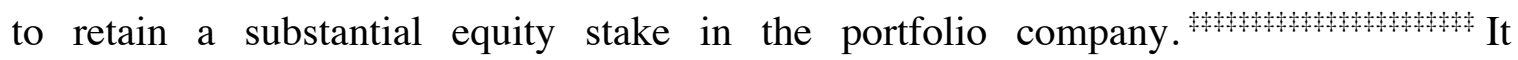
sometimes may take years for a fund to fully sell down its position in a

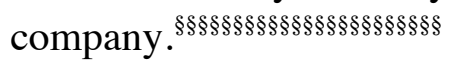

Venture capital firms traditionally take equity positions in young companies and high-tech startups-many of which do not yet have revenues or proven business models - and often focus on finding companies with innovative technologies or business methods. . $^{* * * * * * * * * * * * * * * * * * * * * * *}$ Venture capital firms also structure their funds as limited

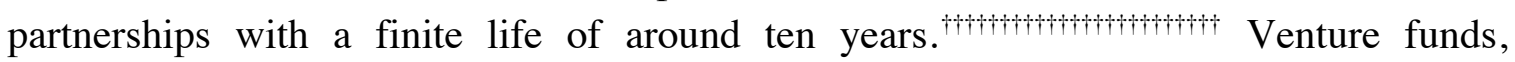

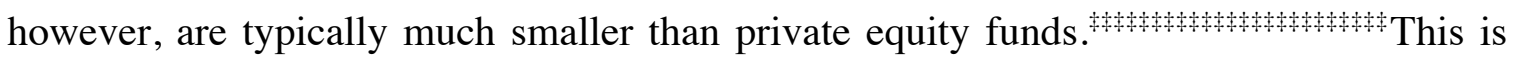
largely explained by the fact that the venture capital business is not as scalable as the

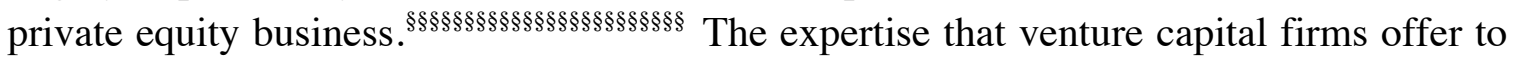
developing companies is not relevant to the more mature firms that are typically owned by private equity. Whereas private equity firms tend to acquire majority stakes, venture capital funds usually acquire minority positions and often syndicate their investments

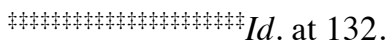

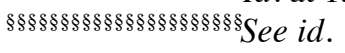

"Sharon Katz, Earnings Quality and Ownership Structure: The Role of Private Equity Sponsors, 64 ACCT. REV. 623, 624 (2009).

At company that was previously taken private in a leveraged buyout-found that buyout group ownership typically decreased from $59 \%$ to $40 \%$ after a public offering, largely due to the dilution from the issuance of new shares. Jerry Cao \& Josh Lerner, The Performance of Reverse Leveraged Buyouts, 91 J. FIN. ECON. 139,143 (2009).

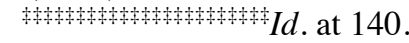

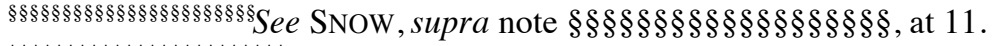

************************* Id. at 10 .

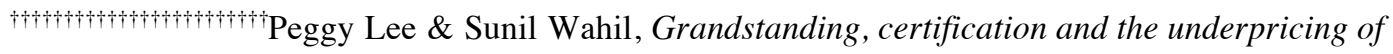
venture capital backed IPOs, 73 J. FIN. ECON. 375, 378-79 (2004).

+ private equity fundraisings, the aggregate target fund size for private equity funds was over three times the target for venture funds. PREQIN, GLOBAL PRIVATE EQUITY REPORT 7 (2012), http://www.preqin.com/docs/samples/preqin_global_private_equity_report_2012_sample_pages.pdf.

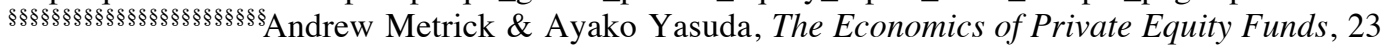
REV. FIN. STUd. 2303, 2337 (2010). 
alongside one another in order to spread risk and share expertise and opportunities. $^{* * * * * * * * * * * * * * * * * * * * * * * *}$ In exchange for their investment, venture capital funds often extract strong and disproportionate control rights from portfolio

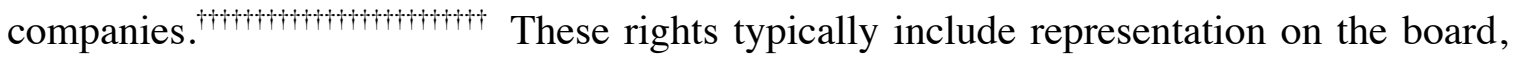
rights to approve outside board members, and approval rights for major company

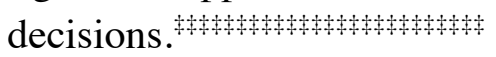

Venture capital funds also invest with an eye towards liquidation so that they can return money to their investors (limited partners). Although only occurring in around ten

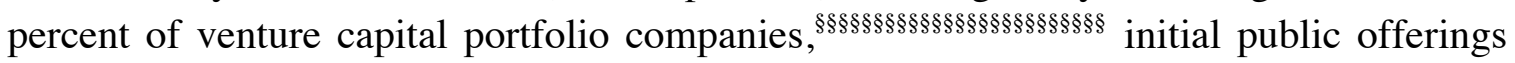
are the most profitable venture capital exit and account for the majority of their investment returns. ${ }^{* * * * * * * * * * * * * * * * * * * * * * * * *}$ IPOs are thus widely viewed as the primary

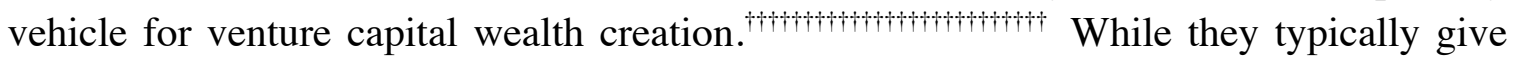
up their disproportionate voting rights, venture funds usually retain a significant portion of their equity holdings after an IPO while they are subject to "lock-up" agreements. limited partners at the expiration of the lock-up, which typically lasts 180 days.

While the private equity industry was once dominated by buyouts of rather large companies in mature industries, today a significant amount of private equity activity consists of middle-market buyouts of privately held companies and acquisitions of

\footnotetext{
***************************e SNOW, supra note $\S \S \S \S \S \S \S \S \S \S \S \S \S \S \S \S \S \S \S$, at 10 .

 Evidence from Acquisitions of Venture-Backed Firms, 46 J. FIN. \& QUANT. ANALYSIS 395, 401 (2011).

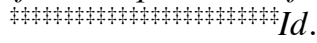

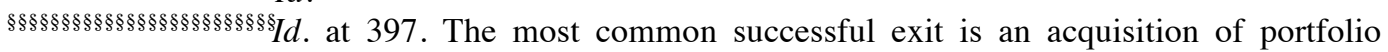
companies by another party, occurring about twenty percent of the time. However, the returns for such exits are substantially lower than returns in IPO exits. See id.

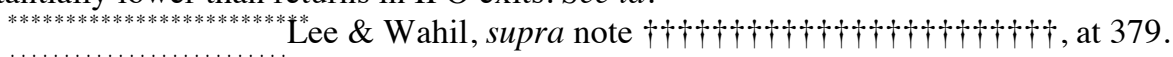

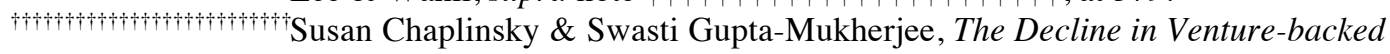
IPOs: Implications for Capital Recovery 4, in HANDBOOK OF RESEARCH ON IPOS (Mario Levis \& Silvio Vismara eds., forthcoming 2013), available at http://papers.ssrn.com/sol3/papers.cfm?abstract_id=2199097.

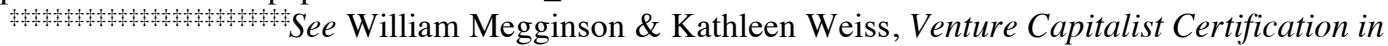
Initial Public Offerings, 46 J. FIN. 879, 899-90 (1991). Megginson and Weiss also found the fraction of issuers with venture capitalists owning a majority stake fell from $28 \%$ to $8.4 \%$ after the IPO. Id.

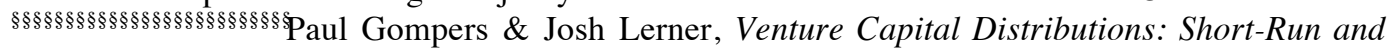
Long-Run Reactions, 53 J. FIN. 2161, 2162 (1998). These distributions do not need to be registered with the SEC. Studies have found significant negative abnormal returns around the expiration of lock-ups in companies with venture capital backing, confirming that they typically sell off or distribute their shares. E.g., Daniel J. Bradley et al., Venture Capital and IPO Lockup Expiration: An Empirical Analysis, 24 J. FIN. ReS. 465, 466 (2001). See also Telis Demos, It's Hard Work Taking Tech Companies Public, WALL. ST. J., Mar. 29, 2013, http://blogs.wsj.com/deals/2013/03/29/its-hard-work-taking-tech-companies-public (describing how sell-offs on shares accompany lock-up expirations).
} 
divisions spun off of large corporations."

Further blurring the line between private equity and venture capital, in recent years, many private equity firms have been investing in growth start-ups and other venture-backed companies.

Private equity funds usually have more limited partners than venture funds because their funds are substantially larger. The limited partners who invest in private equity and venture funds are overwhelmingly institutional investors and wealthy individuals. foundations, endowments, and public pensions funds such as CalPERS (California Public Employees' Retirement System). allocated $\$ 34.5$ billion $-14.6 \%$ of its $\$ 236.5$ billion assets under management - to private equity and venture capital funds, with a typical investment size ranging from $\$ 10$ to $\$ 200$

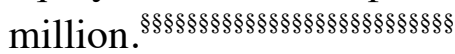

FigURE 1

Limited Partners by Investor Type*

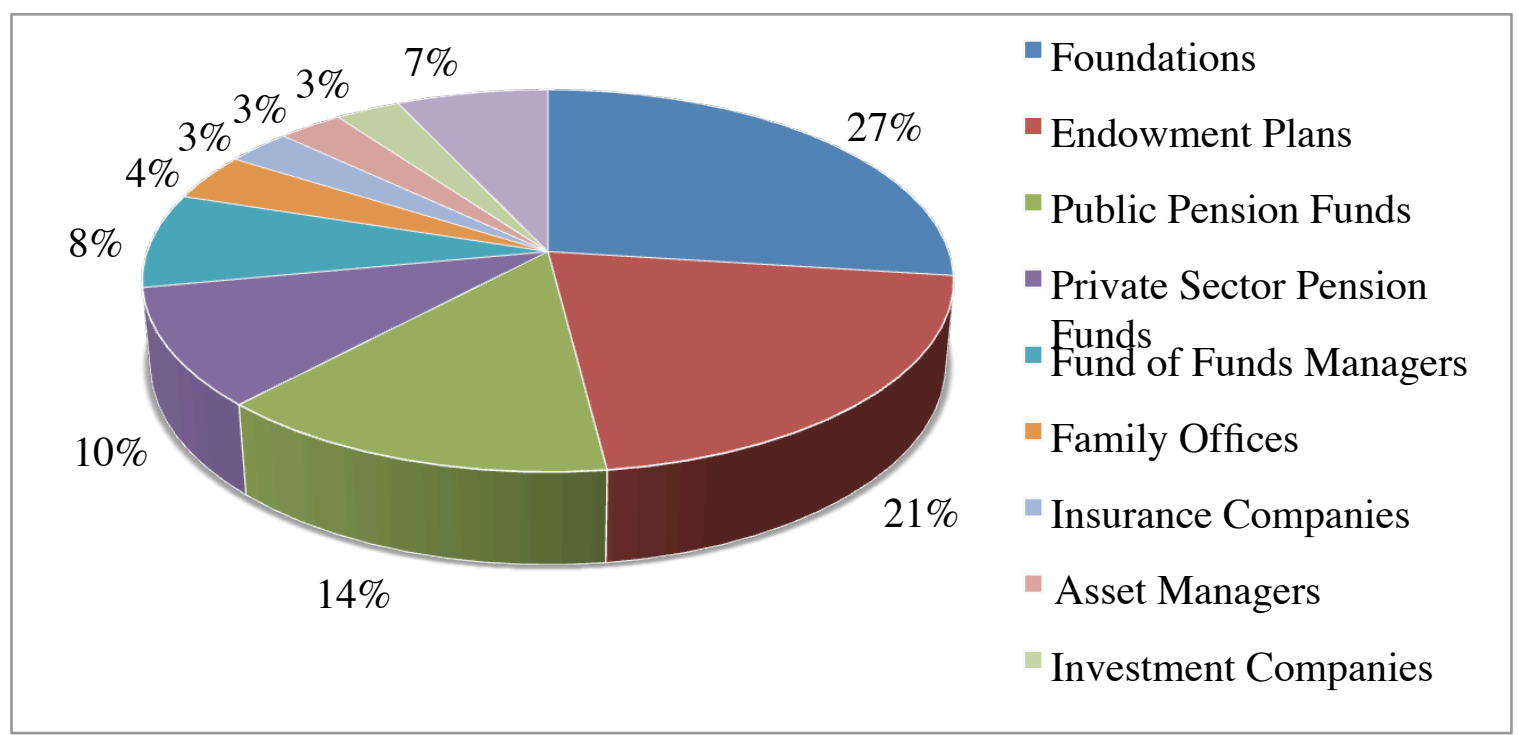

b. Do reputational concerns explain the behavior of PE \& VC firms?

Past studies have generally not found any significant difference in the incidence of takeover defenses such as classified boards in IPO issuers based on private equity or

****************************aplan \& Strömberg, supra note $\S \S \S \S \S \S \S \S \S \S \S \S \S \S \S \S \S \S \S \S$, at 129-30.

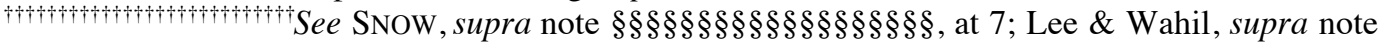

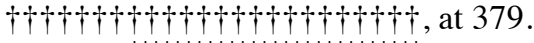

䗇+

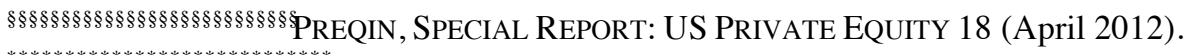

I 


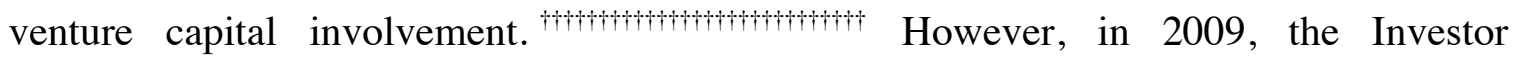
Responsibility Research Center ("IRRC") Institute sponsored a study on the impact of private equity sponsorship on IPO corporate governance and observed that between 2004 and 2006, private equity backed companies had a higher proportion of governance mechanisms such as antitakeover provisions which benefited executives at the expense of

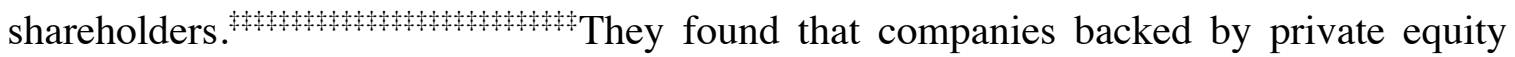
firms were slightly more likely than those without such backing to have a classified board

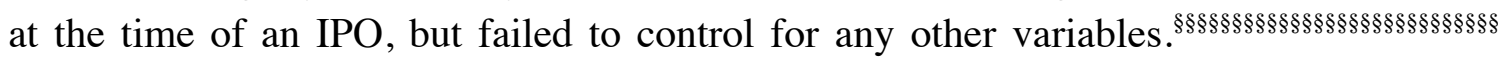
The authors hypothesized "IPO companies are getting more uniform legal advice about the desirability of installing a classified board than was the case during the 1990s.",$* * * * * * * * * * * * * * * * * * * * * * * * * * * * *$ However, when they looked at the prevalence of "effective" classified boards, they found that companies backed by private equity funds were less likely to have effective classification in place than those not backed by such

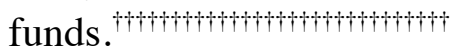

This intriguing phenomenon needs an explanation. Klausner hypothesized that, in the past, this puzzle could have been explained by a lack of institutional knowledge-or just downright ignorance-that sponsored companies were going public with antitakeover provisions in their charters. institutional investor organizations called attention to this in the early 2000s, Klausner suggests "institutions have recently begun to make modest efforts to urge private equity funds to have their portfolio companies adopt takeover-friendly charters when they go

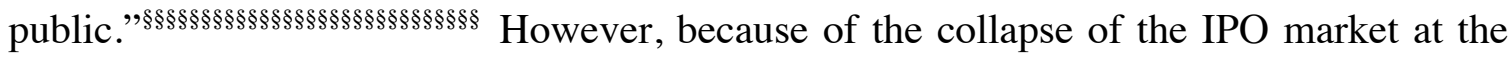
time his article was published, Klausner was not able to perform an empirical study to see whether these efforts were successful."

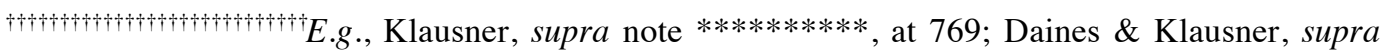
note $\dagger+\uparrow \dagger+\uparrow \dagger \dagger \dagger \dagger$, at 103 ("[i]n all of these regressions, the coefficients on the dummy variables for VCand LBO-backed firms are insignificant"); Field \& Karpoff, supra note ******, at 1871-72. But see

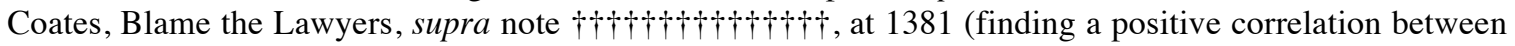
VC-backing and takeover defenses).

 IMPACT OF PRIVATE EQUITY BUYOUT FUND OWNERSHIP ON IPO COMPANIES' CORPORATE GOVERNANCE? 3 (2009), available http://irrcinstitute.org/pdf/What\%20is\%20Impact\%20of\%20PE\%20on\%20CG\%20June\%202009.pdf.

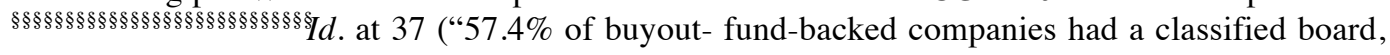
compared with $53.7 \%$ of the other IPO companies").

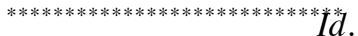

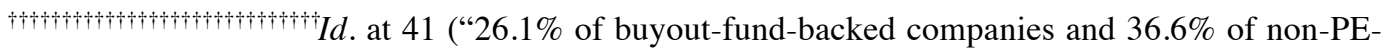
backed companies had effective classified boards"). The IRRC study defined an "effective classified board" in a different way than we define an ESB.

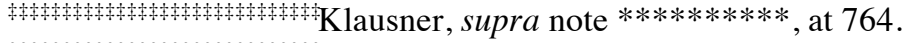

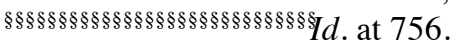

* Id. 
Nevertheless, Klausner put forward a systematic explanation of why these efforts of institutional shareholders seem unlikely to succeed:

Venture capital funds need to attract entrepreneurs in search of funding. In some cases, leveraged buyout firms work the same way, attracting managers seeking to go private or to sell a division. For each type of fund, access to investment opportunities may turn, at least in part, on maintaining a positive reputation for working well with the managers of their portfolio companies, especially successful managers. Consequently, an important concern for a fund considering an institutional investor's demand for takeover-friendly charters is whether the fund's reputation for working well with management is at risk if the fund imposes such a charter on portfolio companies that go public. To be sure, private equity fund managers are known to be tough with portfolio company managers. They fire many before a company goes public. Portfolio company managers in place at the time of an IPO, however, tend to be successful managers. .. . The question, therefore, is whether a fund's insistence on takeover-friendly charters may feed a reputation that the fund is uncooperative with even its most successful managers. This is ultimately an empirical question, but there is reason to expect the answer will be "yes." $\dagger$

In short, Klausner concluded, "the need to attract companies in which to invest seems likely to dominate the views of other private equity funds toward takeover defenses." Indeed, one law firm (Davis Polk \& Wardwell) released a memo that specifically mentions that a fund must balance its near-term desires with the governance preferences of management when the fund sells its stake. ${ }^{\S}$ Another law firm noted, "Certain anti-takeover provisions may benefit the [financial] sponsor by making the company more attractive to sophisticated management . . Although institutional investors generally disfavor anti-takeover defenses, it is possible to include some protection for companies going public without alienating institutional investors."

Bebchuk, however, explains why Klausner's reputation hypothesis is an insufficient explanation for the adoption of takeover defenses by private equity and venture-backed firms. Bebchuk reasons that private equity and venture capital firms only

\footnotetext{
$\dagger$ Id. at $770-71$.

\$Id at 775 .

${ }^{\S}$ Davis Polk \& Wardwell, Post-IPO Charter Provisions for Portfolio Companies (Private Equity Newsletter, Feb. http://www.davispolk.com/1485409/dpw/02_16_06_PrivateEquityNews_feb_06.pdf.

*** Steven Ostner \& Xavier P. Grapotte, Selected Issues to Consider When Taking a Portfolio Company Public (Debevoise \& Plimpton Private Equity Report, Vol. 5. No. 4, Summer 2005), http://www .debevoise.com/files/Publication/23a49307-e9dc-49c8-

94252294f098dd87/Presentation/PublicationAttachment/4cc690c0-55a7-4e4295343488039ce58d/PEReportSummer2005A.pdf.
} 
have an incentive to make implicit future commitments (to managers) that can be expected to increase the expected joint surplus of the parties. ${ }^{\dagger \dagger}$ Absent a joint surplus, the firms would not be expected to deviate from a value-maximizing strategy. ${ }^{\ddagger}$ In fact, a plausible reputation hypothesis would predict that PE-backed companies go public without takeover defenses in order to maximize shareholder value. As private equity firms are repeat players in the IPO market, they have the incentive to ensure the success of their IPOs in order to protect their reputation. ${ }^{\S \S}$ Accordingly, Klausner's hypothesis does not appear to be a sufficient explanation for this behavior. ${ }^{* *}$

c. Agency problems between PE \& VC firms and other pre-IPO shareholders.

Private equity and venture capital funds may use certain takeover defenses to maintain outsize influence on the company after they sell shares when taking it public. A staggered board could allow such a fund to maintain its representation on a company's board of directors for an extended period after taking it public. This may allow the fund to continue to exert substantial control of the company while it sells down whatever ownership positions it still possesses after the public offering. In fact, law firm literature targeted to the private equity industry suggests this as an advantage of maintaining a classified board. ${ }^{\dagger \dagger}$ Additionally, private equity and venture capital firms may have reputational interests in the performance of portfolio companies after taking them public and selling their stakes. For example, if a company is sold at a price below its IPO price 10 months after being taken public by a venture capital firm, it might signal that the venture capital firm took advantage of outside investors in the IPO.

Like the law firm hypotheses, this hypothesis finds its roots in agency problems. While the adoption of a classified board may make shareholders worse off as a group, venture capital and private equity firms may find it in their own interest to include such provisions because they can capture private benefits while other shareholders bear the costs. Management and other pre-IPO investors are likely to be deferential to the guidance of private equity and venture capital firms that almost certainly have more IPO expertise than them. The risk that large investors may treat themselves preferentially at

${ }^{\dagger \dagger}$ Bebchuk, supra note $* * * * * * * * * * * * * * *$, at 747.

\$ See id.

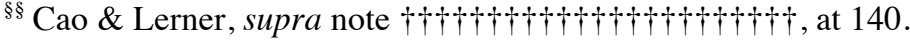

*** Additional reasons to dismiss this hypothesis are discussed infra Part IV.C.2.

${ }^{\dagger \dagger}$ Davis Polk \& Wardell, Post-IPO Charter Provisions for Portfolio Companies (Private Equity Newsletter,

Feb. 2006), http://www.davispolk.com/1485409/dpw/02_16_06_PrivateEquityNews_feb_06.pdf. 
the expense of outsiders is greater when their control rights exceed their cash flow rights. ${ }^{\text {*t: }}$

Venture capital firms often have to give up some of their control rights at the IPO. Such rights typically include guarantees of board seats and veto power over significant firm decisions. As they give up these rights in an IPO, venture capital firms may instead seek to maintain disproportionate control in other ways. An obvious means of doing this is by installing a staggered board. A venture capital or private equity fund can extend its influence on the company as it can have its directors serve out their full three-year terms even though the fund no longer owns any shares of the company. Under the "PE/VC Private Benefits" hypothesis, private equity and venture capital funds use takeover defenses such as an effective staggered board in order to maintain and extract private benefits of control at the expense of other shareholders.

Alternative Hypothesis $3 \boldsymbol{b}$. The presence of private equity or venture capital backing has a positive relationship with a company's pre-IPO adoption of takeover defenses.

\section{d. $\quad P E \& V C$ firms as substitutes for external market for control.}

I test the validity of the Institutional Investor Efficiency and PE/VC Private Benefits hypotheses against the null hypothesis that private equity and venture capital backing does not affect the presence of takeover defenses at an IPO. The primary argument for this null hypothesis was put forward by Malcolm Baker and Paul Gompers. They hypothesize that financial sponsors such as venture capitalists may institute better internal governance mechanisms that serve as substitutes for the external market for corporate control for portfolio companies. ${ }^{\S \S}$ With such mechanisms in place, takeover defenses may have little to no effect on firm performance in these portfolio companies. Therefore, the presence of venture capital or private equity backing may be unrelated to the presence of a classified board. This null hypothesis is also referred to as the "Substitute Governance" hypothesis.

Alternative (Null) Hypothesis 3c. There is no relationship between the presence of private equity or venture capital backing and a company's pre-IPO adoption of takeover defenses.

Financial sponsors certainly can serve as a substitute governance mechanism in their privately held portfolio companies. On its face, however, this hypothesis is rather unpersuasive for public companies. As previously mentioned, private equity and venture

Andrei Shleifer \& Robert W. Vishny, A Survey of Corporate Governance, 52 J. Fin. 737, 758 (1997).

$\$ \$ \S$ Malcolm Baker \& Paul A. Gompers, The Determinants of Board Structure at the Initial Public Offering, 46 J. FIN. 569, 579 (2003). 
capital funds are limited in duration and need to eventually exit their investments. Although they may not immediately sell their entire stakes at an IPO, they rarely are long-term holders of public company stock. And once a portfolio company is public and traded on a liquid market, the financial sponsor loses its incentive to exercise its voice. ${ }^{* * * *}$ Thus, shareholders are unlikely to value this "substitute" governance mechanism. One can argue that new corporate blockholder(s) may replace the financial sponsors and fulfill their substitute governance role. However, a study by Field and Sheehan found that only $41 \%$ of firms with a corporate blockholder in place at the IPO had a new corporate blockholder one year later. ${ }^{\dagger \dagger \dagger}$ And the new blockholder had a board seat in only $4 \%$ of their sample. ${ }^{*+1}$

\section{Managerial entrenchment and private benefits.}

Managerial agency costs may also help explain why takeover defenses may be adopted at an IPO even though they are inefficient. Management may be willing to bear the cost of a lower offering price caused by takeover defenses because the private benefits of control (utility) that they derive from the defenses may outweigh the costs of having a lower public valuation of the company. ${ }^{\S \S \S}$ This has come to be known as "managerial entrenchment," defined by Berger, Ofek, and Yermack as "the extent to which managers fail to experience discipline from the full range of corporate governance and control mechanisms." "***** In a study of IPO underpricing, Brennan and Franks argued that a firm's incumbent management might structure an IPO in order to insulate themselves from the discipline imposed by the market for corporate control and maintain their private benefits of control once the company is publicly traded. ${ }^{+t i \dagger}$ There are multiple reasons why management may value control at an idiosyncratically high level. One can easily imagine the non-pecuniary aspects of entrepreneurial activities such as the

**** See Marco Becht, Patrick Bolton \& Alisa Röell, Corporate Governance and Control 18 (European Corp. Gov. Inst. Working Paper No. 02/2002 2005), available at http://unpan1.un.org/intradoc/groups/public/documents/apcity/unpan033582.pdf; ALBERT O. HIRSCHMAN, EXIT, VOICE, AND LOYALTY: RESPONSES to DECLINE IN FIRMS, ORGANIZATIONS, AND STATES 51 (1970).

${ }^{\dagger \dagger}$ Laura C. Field \& Dennis P. Sheehan, IPO underpricing and outside blockholdings, 10 J. CORP. FIN. 263, 275 (2004).

Id. at 274 .

$\S \S \S$ Bebchuk, supra note $* * * * * * * * * * * * * * *$, at 733. In a 1976 paper, Jensen and Meckling implied that managers may forgo the adoption of a value-maximizing capital structure in order to entrench themselves against pressures from corporate governance mechanisms. See generally Michael C. Jensen \& William H. Meckling, Theory of the Firm: Managerial Behavior, Agency Costs and Ownership Structure, 3 J. FIN. ECON. 305, 312-13 (1976).

${ }^{* * * * *}$ Philip G. Berger, Eli Ofek, \& David L. Yermack, Managerial Entrenchment and Capital Structure Decisions, 92 J. FIN. 1411, 1411 (1977).

${ }_{\dagger \dagger \dagger}$ Michael J. Brennan \& Julian Franks, Underpricing, ownership and control in initial public offerings of equity securities in the UK, 45 J. FIN. ECON. 391, 394-95 (1997). 
prestige associated with management position, the physical appointments of the office, the social status it comes with, and personal relations with employees. ${ }^{*+*}$

Field and Karpoff followed this line of inquiry and examined whether managers use takeover defenses as a mechanism to maintain their private benefits of control after taking a company public. ${ }^{\S \S \S \S}$ Under this theory, non-managerial shareholders bear much of the costs of takeover defenses while managers disproportionately benefit from the nonpecuniary benefits of the defenses. As insider ownership decreases, non-managerial shareholders bear a larger portion of the costs of management decisions. Therefore, Field and Karpoff hypothesized that defenses would be more prevalent at firms where management owns fewer shares. Using a dataset of IPOs from 1988 to 1991, they found that managers deploy takeover defenses when they own few shares, are highly compensated, and are subject to weak monitoring by non-managerial shareholders." These results were consistent with their hypothesis that IPO managers deploy takeover defenses when their personal benefits are high and they only bear a small portion of the costs. However, a concurrent study by Daines and Klausner reached the opposite result, finding that defense adoption increases as insider's pre-IPO share ownership increases. ${ }^{t+1+\dagger}$

While, on average, takeover defenses may entrench management to the detriment of shareholders, it is also possible that the use of such provisions may be efficient in some situations. The most common theory is that takeover defenses provide incumbent management with bargaining power, allowing them to expropriate to their shareholders a larger portion of the value of an eventual merger transaction. However, Field and Karpoff found that takeover defenses at the time of the IPO are associated with longer-term firm independence (a lower probability of being acquired within five years) and that IPO takeover defenses did not have a statistically significant relationship with takeover premiums. In a concurrent study, Daines and Klausner also found that the bargaining power hypothesis does not explain the adoption of takeover defenses. ${ }^{\S \S \S \S \S}$ In fact, they found the opposite: takeover defenses are more protective where the hypothesis predicted they are the least efficient.

As previous studies have reached conflicting results, I examine whether the "Management Entrenchment" hypothesis can explain the adoption of takeover defenses at an IPO. I focus on four variables as proxies for measuring managers' personal benefits of control.

$\$$ ¡ Jensen \& Meckling, supra note $\S \S \S$, at 312.

$\$ \$ \$ \S \S$ Field \& Karpoff, supra note $* * * * * *$, at 1858.

${ }^{* * * * * * *} I d$.

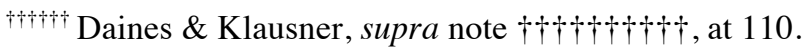

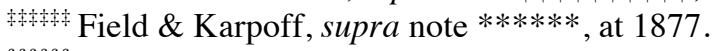

$\$ \S \S s \&$ Daines \& Klausner, supra note $\uparrow+\uparrow+\uparrow+\uparrow \dagger \uparrow \dagger$, at 102. 
Hypothesis 4. Companies are more likely to have strong takeover defenses when the private benefits of control are high. Therefore, takeover defenses should be positive correlated with CEO-Chair and CEO-Founder, and negatively correlated with CEO-Age and Insider.

First, I examine whether the Chief Executive Officer ("CEO") of the IPO company is also a founder of the company. Recall that Coates argued "entrepreneurs may place special value on companies they create, and long association can create attachments making control, with assurance of continued association, uniquely valuable to an individual."******** Additionally, whenever founders bring in more outside investors, the chances that they will be replaced increases dramatically. ${ }^{.+1+\dagger}$ Therefore, a founding CEO will want to preserve excess control in order to better secure his position and its associated benefits in the future. The managerial private benefits hypothesis suggests that the inclusion of an effective staggered board should be positively related to the presence of a founding CEO. While Daines and Klausner found that the presence of a founding CEO had no significant effect on a firms' adoption of anti-takeover provisions, Coates found that it was positively associated with the presence of more defenses.$^{\S \S \S \S \S \S}$

I include data on whether the firm's CEO also serves as the chairman of the firm's board. One reason that public companies have a board of directors is to minimize the agency costs resulting from the separation of management and control. Thus, a central purpose of the board is to hold management accountable on behalf of dispersed shareholders. As posited by Eugene Fama and Michael Jensen, a board that is dominated by the CEO is not an effective monitor of management. ${ }^{* * * * * * *}$ Such a board cannot effectively perform its internal control function and is more likely to acquiesce to the CEO than an independently lead board. A CEO who serves as board chairman may therefore have substantial control over the choice of the firm's governance structure. In fact, Field and Karpoff found that takeover defenses were more likely to be used when a company's CEO served as its board chairman, and concluded that firms with weak controls over senior management were more likely to use takeover defenses. ${ }^{\text {itititi }}$

\footnotetext{
${ }^{* * * * * * *}$ Coates, Blame the Lawyers, supra note $\uparrow+\uparrow+\uparrow \uparrow \uparrow+\uparrow \uparrow \uparrow \uparrow+\uparrow \dagger$, at 1331.

†t+iti Michael J. Roberts, The Founding CEO's Dilemma: Stay or Go?, HBS WORKING KNOWLEDGE, Aug. 15, 2005, http://hbswk.hbs.Fedu/item/4948.html.

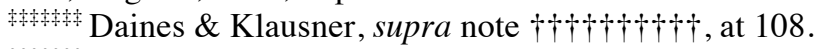

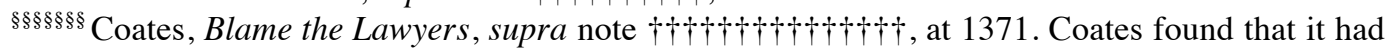
a statistically significant positive correlation with his "Contestability Index" dependent variable, which represented the number of days it would take for a hostile bidder to overcome management resistance to a bid. However, he did not find a significant correlation between a founding CEO and a classified board.

${ }^{* * * * * * * * *}$ Eugene F. Fama \& Michael C. Jensen, Separation of Ownership and Control, 26 J. LAW \& ECON 301, 314 (1983). It is easy to see why a board led by management may not hold management accountable.

${ }^{\dagger \dagger \dagger \dagger \dagger \dagger}$ Field \& Karpoff, supra note $* * * * * *$, at 1871. This finding was statistically significant.
} 
I also account for the age of the CEO at the time of the IPO. Field and Karpoff hypothesized that the present value of personal pecuniary and non-pecuniary benefits of control over a company is inversely related to the CEO's age. This assumes that older CEOs are more likely to leave the workforce sooner and therefore will not be able to enjoy the private benefits of control as much as a younger CEO would be able to enjoy them. Indeed, they did find such a negative relationship between CEO age and the likelihood of a takeover defense.

Finally, I look at the percentage of a company's common stock that is owned by directors and officers before the IPO. Under SEC regulations, a company is required to furnish the aggregate total percentage of stock beneficially owned by all directors and executive officers in its registration statement. ${ }^{\S \S \$ \$ \$ \S \S}$ The management entrenchment hypothesis suggests that the portion of the costs of takeover defenses born by management decreases as their equity position in the company decreases. Therefore, one may expect a negative relationship between insider stock ownership and the presence of takeover defenses. Regulation S-K, 17 C.F.R. § 229.403. 
TABLE 1

Overview of Hypotheses and Predicted Signs

\begin{tabular}{|c|c|c|c|c|c|c|c|}
\hline Hypothesis & $1 a$ & $1 b$ & 2 & $3 a$ & $3 b$ & $3 c$ & 4 \\
\hline Variable & 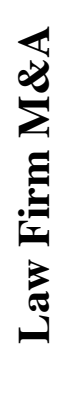 & 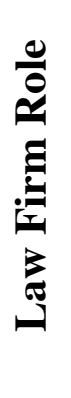 & 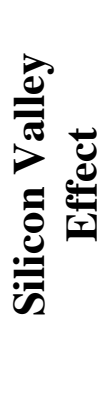 & 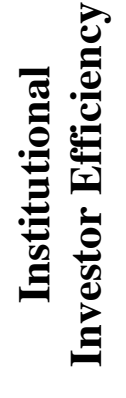 & 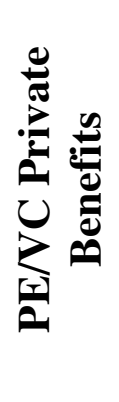 & 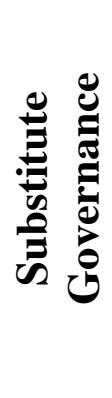 & 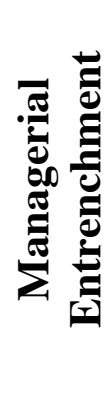 \\
\hline $\begin{array}{l}\text { Law Firm's Target } \\
\text { Experience }\end{array}$ & + & + & & & & & \\
\hline $\begin{array}{l}\text { Law Firm's Acquirer } \\
\text { Experience }\end{array}$ & + & - & & & & & \\
\hline $\begin{array}{l}\text { Silicon Valley Law } \\
\text { Firm }\end{array}$ & & & + & & & & \\
\hline $\begin{array}{l}\text { Private Equity } \\
\text { Backing }\end{array}$ & & & & - & + & $\mathrm{ns}$ & \\
\hline $\begin{array}{l}\text { Venture Capital } \\
\text { Backing }\end{array}$ & & & & - & + & $\mathrm{ns}$ & \\
\hline CEO-Founder & & & & & & & \\
\hline CEO-Chairman & & & & & & & \\
\hline CEO Age & & & & & & & \\
\hline Insider Ownership & & & & & & & \\
\hline $\begin{array}{l}\text { Dependent variables: } E S \\
\mathrm{~ns}=\text { not significant }\end{array}$ & & & $-i r$ & & & & \\
\hline
\end{tabular}




\section{DATA DESCRIPTION}

\section{A. Dependent Variables}

Initial data on the IPOs was retrieved through the Thomson Financial Securities Data Company (SDC) Platinum New Issues database. For each company in the sample, data on the presence of takeover defenses was collected from FactSet's SharkRepellent database and supplemented with data from the IRRC Governance database. Additional data was manually collected data from issuers' registration statements, charters, and bylaws, ${ }^{* * * * * * * *}$ which companies are required to file with the SEC (and available online via the SEC's EDGAR database).

\section{Effective staggered board.}

Most previous studies of takeover defenses often focus on the mere presence of a classified board without giving weight to whether the classification is effective when facing a hostile bidder. It is not entirely uncommon for companies to have ineffective staggered boards as a result of gaffes in defensive planning. ${ }^{+1+t^{+1+\dagger}}$ Therefore, I use a dummy variable indicating the presence of an effective staggered board ("ESB") as my primary dependent variable. ESB data was compiled in accordance with Bebchuk, Coates, and Subramanian. ${ }^{+t_{0+1}}$ In short, an ESB exists when a theoretical hostile acquirer with a simple majority of the vote cannot overcome a target's staggered board in less than two annual elections. To be classified as an ESB, first, the charter for each company was reviewed to see if it included a classified board. ${ }^{\S \S \S \S \S \S \S \S}$ If the classified board appeared in the bylaws instead of the charter, then there must have been a supermajority $\left(66^{2} / 3\right.$ percent) requirement to amend the bylaws in order for the board to be classified as an ESB. Second, the charter must not allow for the removal of directors without cause or must require a supermajority of the shareholder vote to remove a director without cause. If the charter is silent on the issue then the default law of the company's state of incorporation comes into play. (If it was a Delaware company, the default law prohibits removal of directors without cause. . $^{* * * * * * * * *}$ If it was another state

${ }^{* * * * * * * * *}$ As the SharkRepellant data is regularly updated, I also checked its data on charter and bylaw amendments to ensure that the sample includes the data as of the IPO date and excludes subsequent changes.

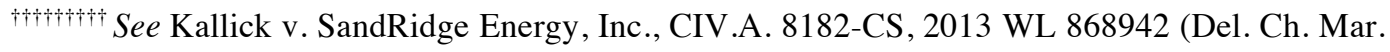
8,2013 ) (describing a staggered board implemented by bylaw as a "defensive planning flaw").

$\neq+\cdots+$ BCS, Effective Staggered Boards, supra note ****, at 913.

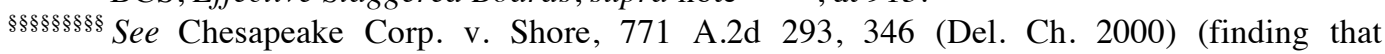
stockholders have the power to eliminate classified board structures embedded in the bylaws).

${ }^{* * * * * * * * *}$ See DEL. CODE ANN. tit. 8, $§ 141(\mathrm{k})$; BCS, Effective Staggered Boards, supra note ****, at 910 . 
then the default law generally allowed removal without cause. ${ }^{+1+t_{t+1+\dagger \dagger}}$ ) Additionally, shareholders must not be able to "pack the board" by increasing the number of directors and filling the vacancies created. ${ }^{*}+1+1+*$ Therefore, charters and bylaws were reviewed to see if directors had the right to fill all board vacancies and if shareholders had the right to increase the size of the board. If such provisions were exclusively located in the bylaws and subject to amendment by a simple majority vote of shareholders, then the board was not considered an ESB. Finally, a company's board must have had the ability to adopt a poison pill without shareholder approval — or have already adopted a pill — in order to be

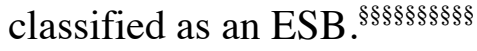

\section{E-Index.}

An alternative measure of takeover defenses is the Bebchuk, Cohen, and Ferrell entrenchment index (E-Index). Each company in the sample was given a score, between zero and five, based on the number of provisions that the company had at the time of its IPO. ${ }^{* * * * * * * * * * * *}$ The relevant provisions were: (1) a classified board; (2) a provision limiting shareholders' ability through majority vote to amend the corporate bylaws; (3) a provision limiting shareholders' ability through majority vote to amend the corporate charter; (4) a requirement that requires more than a majority of shareholders to approve a merger; and (5) the ability of the board to adopt a "morning-after" poison pill. While Bebchuk et al.'s original E-Index considers whether a board has a poison pill in place, my modified version merely considers whether it is possible for a board to adopt a poison pill without shareholder approval. (It is irrelevant whether or not a company actually has a pill in place if it can adopt a "morning-after" poison pill as soon as it is faced with a hostile bid. check preferred stock and that the company's charter did not have an "anti-poison pill” provision or a requirement for shareholders to approve a poison pill prior to its adoption.

\section{Dual class stock.}

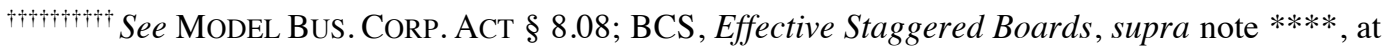
910.

BCS, Effective Staggered Boards, supra note ****, at $910 \mathrm{n} .84$. If a charter did not reserve the size of the board to the board directors, then shareholders can increase the size of the board. If shareholders can also fill vacancies, then they can pack the board. See DEL. CoDE ANN.. tit. 8, § 141(b), § 142(e); MODEL Bus. CORP. ACT § 8.03(a), § 8.10(a).

§§§§§§§§§ $\mathrm{A}$ board that is authorized to issue blank-check preferred stock can adopt a pill unless the charter prohibits it.

See generally Bebchuk, Cohen \& Ferrell, supra note ******* (introducing the E-Index).

thitit+tit While the original E-Index utilizes 6 provisions, I did not include the presence of a "golden parachute" in my calculations because such provisions are rare at IPO companies.

See John C. Coates IV, Takeover Defenses in the Shadow of the Pill: A Critique of the Scientific Evidence, 79 TEX. L. REV. 271, 288 (2000); Daines \& Klausner, supra note $+\dagger+\dagger+\dagger \dagger \dagger+\dagger$, at 86. 
A potent takeover defense that can substitute for a classified board is a dual class capital structure where management or pre-IPO shareholders hold a controlling class of high-vote stock. Dual class capital structures are "qualitatively different from other types

of defenses." $\$ \S \S \S \S \S \S \S$ In such a structure, one class of shares can have superior voting rights ("supervoting" shares) to another class that has ordinary voting rights (one share, one vote). ${ }^{* * * * * * * * * * *}$ Entrepreneurs, venture capital and private equity firms, and other preIPO insiders typically hold on to the shares with superior voting rights after the IPO in order to maintain effective control over the firm (even though they may no longer own a majority of its stock). ${ }^{+t+t+t+t+t}$ The ordinary shares are typically sold to outside investors during the IPO. By maintaining a controlling vote of the stock, the insider is fully insulated from the takeover market. Therefore, a classified board is not necessary to frustrate hostile bidders in firms with dual class structures including a "supervoting" (control) class.

Registration statements were reviewed to see whether a company had multiple classes of common stock at the IPO. An IPO was flagged as having an effective dual class control structure (DualClassControl=1) if the stock being sold was lower vote stock than the stock held by the largest pre-IPO shareholder, or if no vote stock is being

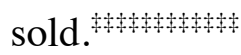

\section{B. Independent Variables of Interest}

\section{Law firm hypotheses.}

The identity of the law firm serving as primary counsel for each IPO company and of their corresponding office locations was taken from the SDC New Issues database. If multiple law firms were listed in SDC, I identified primary counsel by reviewing the registration statement to see which firm was listed first and issued an opinion on the legality of the offering. $\$ \S \S \S \S \S \S \S \S \S \S$

Law firm M\&A experience is primarily represented by two variables: Target Deals and Acquirer Deals. Target Deals is equal to the number of deals that the issuer's law firm served as primary counsel to a public target company in the three-year period

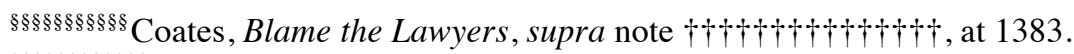

${ }^{* * * * * * * * * * * *}$ See generally Thomas J. Chemmanur \& Yawen Jiao, Dual class IPOs: A theoretical analysis, 36 J. BANKING \& FIN. 305, 305 (2012).

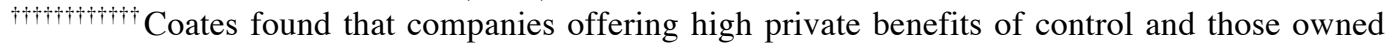
by individuals or families were more likely to adopt dual class control structures. Coates, Blame the

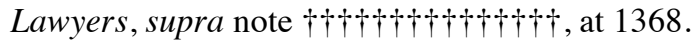

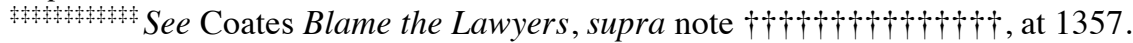

$\S \S \S \S \S \S \S \S \S \S \S$ This legal opinion can be found as Exhibit 5 to a Registration Statement (S-1) and is required by the SEC. Item 601 (Exhibits) of Regulation S-K, 17 C.F.R. $§ 229.601$.
} 
prior to the IPO. Acquirer Deals is equal to the number of deals that the issuer's law firm served as primary counsel to a public company acquirer in the same period. This data was extracted from the SDC Platinum Merger \& Acquisition database. In order to focus on deals that involved some risk of a hostile bid, deals were only included if they involved majority acquisitions of public companies lacking controlling shareholders with a market capitalization of at least $\$ 10$ million (consistent with Coates).

A law firm was flagged as a Silicon Valley firm (Silicon Valley Law=1) if the registration statement indicated the law firm was located in Silicon Valley ${ }^{* * * * * * * * * * * * *}$ and was flagged as New York firm (NY Law=1) if it was located in New York, NY. Data on the total number of the lawyers working at a firm was primarily taken from the American Lawyer's 2012 AmLaw200 publication. For smaller firms not included in the top 200, data was manually collected from the NALP Directory of Legal Employers or the law firm's website. IPOLAW represents the number of IPOs in the sample for which a company's law firm served as primary counsel.

\section{Private equity \& venture capital hypotheses.}

The presence of venture capital and private equity backing are indicated through the use of categorical variables. Private Equity is a dummy variable equal to 1 if a company is backed by a private equity firm at the time of its IPO. Venture Capital is a dummy variable equal to 1 if a company is backed a venture capital firm at the time of its IPO.

To construct these variables, I reviewed the final registration statement for each IPO and recorded the top three institutional shareholders and their stakes. In order to minimize measurement error, I primarily relied on an external source to classify the shareholders. I searched for each firm in the Dow Jones Private Equity \& Venture Capital database and recorded whether Dow Jones labeled a firm a venture capital firm or a

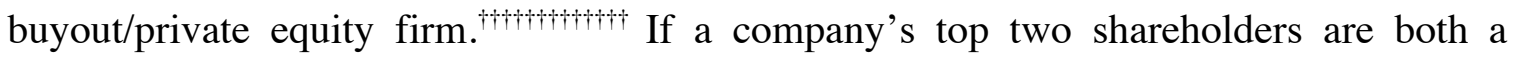
private equity and venture capital firm owning significant and similar stakes, the company is classified as being backed by both. Lastly, I separately noted whether one of the top three shareholders was a mutual fund or public pension fund.

\section{Management entrenchment hypothesis.}

CEO-Founder is a dummy variable equal to 1 if the CEO is also a founder of the company. CEO-Chair is a dummy variable equal to 1 if the CEO also serves as the

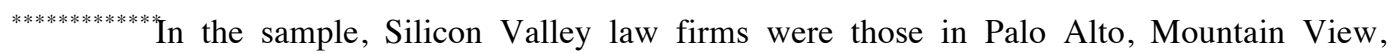
Redwood City, Menlo Park, or San Francisco, California.

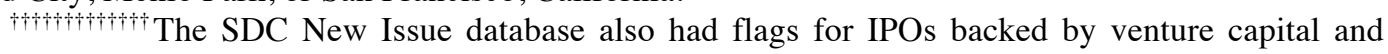
private equity firms. However, the SDC flags were often inaccurate and inconsistent.
} 
chairman of the board. CEO Age is the age of the CEO at the time of the IPO. Insider is the percentage of a company's common stock that is owned by directors and officers before the IPO. I collected information on CEO-Founder, CEO-Chair, and CEO-Age by examining the "Management" section of the registration statement of each

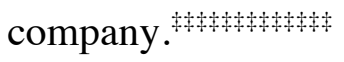

\section{Other Explanatory and Control Variables}

Basic IPO data, such as the market capitalization of the company (Market Cap.), the size of the offering as a percentage of the market capitalization (IPO Float), the assets at the time of the IPO (Assets), whether the IPO was a RLBO or spin-off (Spinoff), ${ }^{\S \S \S \S \S \S \S \S \S \S \S}$ the year of the offering, and other financial data at the time of the offering, came from the SDC New Issues database. This data was amended and supplemented by Jay Ritter's Corrections to SDC's IPO database file, ${ }^{* * * * * * * * * * * * * * *}$ and his

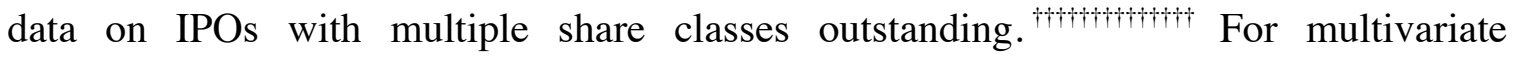
regressions, Market Cap is an important control variable as firms with a smaller market capitalization are more likely to be acquired because there are inherent impediments and complexities to acquiring larger companies.

Company Age was calculated using founding date data from SDC, and amended by Jay Ritter's IPO founding date spreadsheet. ${ }^{\S \S \S \S \S \S \S \S \S \S \S}$ It serves as a proxy for more mature firms, which likely have more tangible assets, more seasoned management, and a lower potential for growth. . $^{* * * * * * * * * * * * *}$ The location of a firm's headquarters was also assembled from SDC. Delaware, a dummy variable indicating whether a firm is incorporated in Delaware was created using data from each prospectus. As the default law in states other than Delaware generally leaves companies less vulnerable to

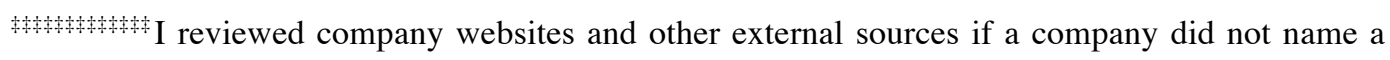
chairman in the registration statement.

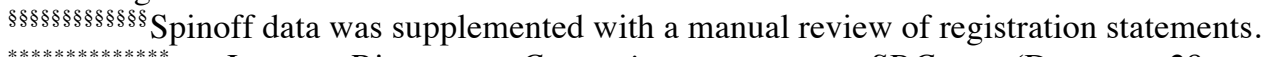

Jay Ritter, Corrections to SDC (Dec. 28, 2011), http://bear.warrington.ufl.edu/ritter/SDC\%20corrections122811.pdf.

†t+

2012), http://bear.warrington.ufl.edu/ritter/dualclassIPOs19802012_052012.xls (accessed Jan. 20, 2013).

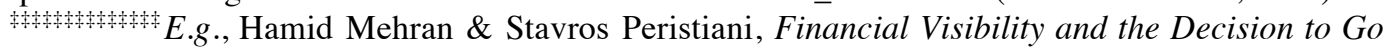

Private, 23 REV. FIN. STUD. 519, 529 (2010).

$\S \S \S \S \S \S \S \S \S \S \S \S$ Laura C. Field \& Jay Ritter, Founding dates for 9,262 firms going public in the U.S.

during 1975-2010 (Jan. 2011), http://bear.warrington.ufl.edu/ritter/FoundingDates.htm (as used in Tim

Loughran \& Jay Ritter, Why Has IPO Underpricing Changed Over Time?, 33(3) FIN. MGMT. 5 (2004);

Field \& Karpoff, supra note ******, at 1857.

C. N. V. Krishnan et al., Venture Capital Reputation, Post-IPO Performance, and Corporate Governance, 46 J. FIN. \& QUANT. ANALYSIS 1295, 1303 (2011). 


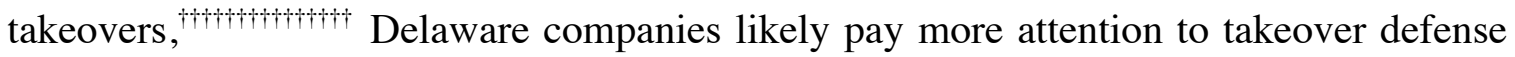
issues than companies incorporated in other states.

Standard industrial classification ("SIC") codes were obtained through the SDC New Issues database. Companies were classified as belonging to a "high-tech" industry $(H I G H T E C H=1)$ if their three-digit SIC indicated they were in the computer equipment (357), software (737), electronics (367), medical instruments (384), and biotech (283 \& 809) industries. ${ }^{+f_{1}}$ (Industry $M \& A$ ) was calculated by totaling the number of acquisitions involving targets with the same 3-digit SIC code as the IPO firm in the three years prior to the

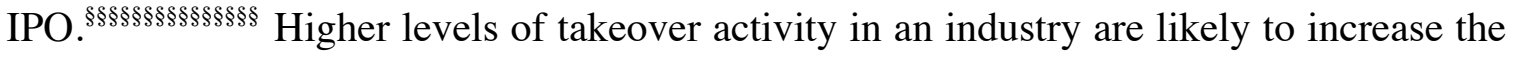
visibility of antitakeover provisions to company management and financial sponsors. This, in turn, may increase their desire for takeover defenses irrespective of their efficiency.

Registration statements were reviewed to see whether a company had multiple classes of common stock at the IPO (DualClass=1). An IPO was flagged as having an effective dual class structure (DualClassControl=1) if the stock being sold was lower vote stock than the stock held by the largest pre-IPO shareholder, or if "no vote" stock is being sold."

\section{Description of Empirical Sample}

The sample contains 259 initial public offerings (IPOs) for U.S. companies that occurred between January 2008 and December 2012.. The sample excludes IPOs with an offer price below one dollar, IPOs that did not take place on a U.S. exchange, and IPOs

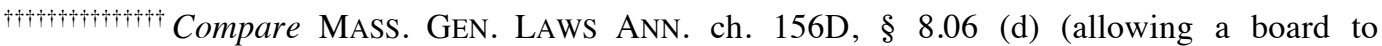
effectively classify itself without a shareholder vote) and MD. CODE ANN., CORPS. \& ASS'NS § 3-602 (prohibiting business combination transactions with a $10 \%$ shareholder for a period of 5 years unless board approval is obtained before the $10 \%$ threshold is crossed) with DEL. CODE ANN. tit. 8, § 203 (prohibiting business combinations transactions with a $15 \%$ shareholder for a period of only 3 years and providing numerous exceptions).

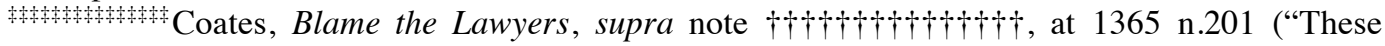
industries drive Silicon Valley.").

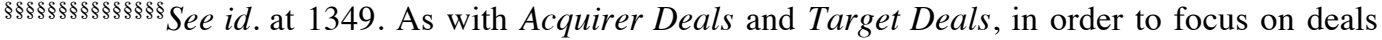
that involved some risk of a hostile bid, transactions were only counted if they involved majority acquisitions of public companies lacking controlling shareholders with a market capitalization of at least $\$ 10$ million.

See id. at 1357. 
for closed-end funds, trusts, real estate investment trusts (REITs), and Special Purpose Acquisition Companies (SPACs) ${ }^{\text {it+titititititit }}$

\section{Qualitative Data}

Although I primarily rely on empirical research throughout this paper, I also make use of qualitative data. At points in the paper, I utilize governance and proxy voting policies of institutional investors. The SEC requires mutual funds to disclose their proxy

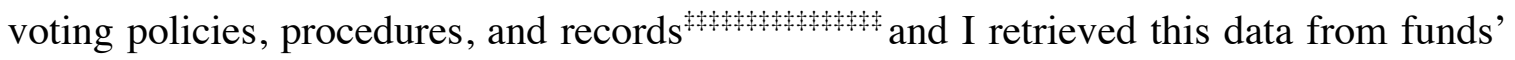
websites and SEC filings. I also conducted numerous unscripted interviews with practitioners with experience related to IPOs. The interviewees included partners at M\&A-focused law firms, including Wachtell Lipton and Sullivan \& Cromwell, partners at private equity law firm Schulte Roth \& Zabel, a managing partner at a venture and startup-focused law firm, and numerous principals at private equity and venture capital funds based in Silicon Valley, New York, and Boston.

\section{EMPIRICAL RESULTS}

\section{A. Descriptive Data}

\section{Issuer characteristics.}

The sample includes of a wide range of well-known issuers such as Facebook, General Motors, Zipcar, and Visa. Table 2 lists the summary statistics for the entire sample of 259 IPO issuers. A massive $27 \%$ of the companies had their headquarters

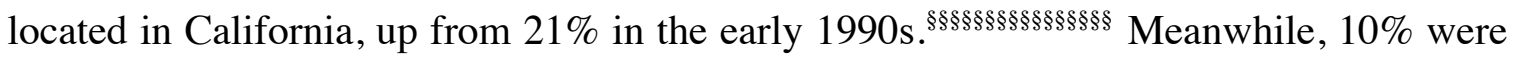
headquartered in Texas. Only 4\% had headquarters in New York-representing a 60\% decline since the Coates study. in Delaware, $91 \%$ of the companies were incorporated in Delaware. This follows the growing trend observed in the Coates study, which found that $62 \%$ of IPO companies

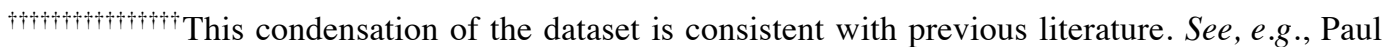
A. Gompers \& Andrew Metrick, Extreme Governance: An Analysis of Dual-Class Firms in the United States, 23 REV. FIN. STUD. 1051, 1055 (2010); Field \& Karpoff, supra note ******, at 1859.

$+4+1+0$ Disclosure of Proxy Voting Policies and Proxy Voting Records by Registered Management Investment Companies, 68 Fed. Reg. 6564, 6564 (Feb. 7, 2003) (codified at 17 CFR pts. 239, 249, $279 \& 274$ (2013)). The SEC believed that disclosure would "illuminate potential conflicts of interest and discourage voting that is inconsistent with fund shareholders' best interests" and that increasing the transparency of proxy voting by funds would lead funds to become more engaged in corporate governance issues. Id. at 6566.

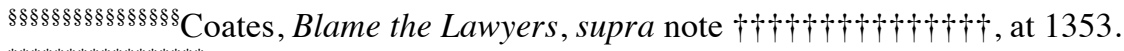

******************* See id. 
were incorporated in Delaware in 1991-92 and 75\% were in 1998-99. is prima facie evidence of Delaware's continued dominance over corporate law,

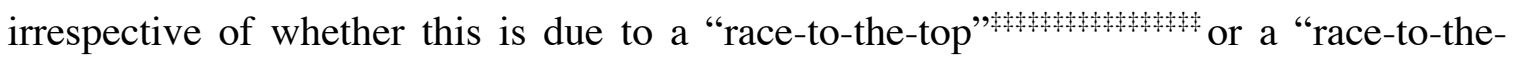
bottom." $§ \S \S \S \S \S \S \S \S \S \S \S \S \S$

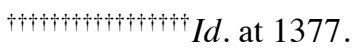

See, e.g., Ralph K. Winter, Jr., State Law, Shareholder Protection and the Theory of the Corporation, 6 J. LEGAL STUD. 251 (1977) (arguing that state competition for corporate law is efficient because it produces high quality law); Roberta Romano, The Political Economy of Takeover Statutes, 73 VA. L. REV. 111 (1987).

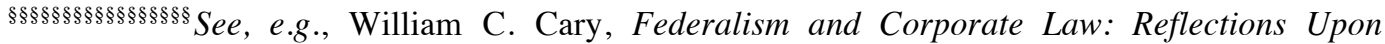
Delaware, 83 YALE L.J. 663 (1974) (hypothesizing that state competition will result in in a choice of inefficient law); Lucian A. Bebchuk, Federalism and the Corporation: The Desirable Limits on State Competition in Corporate Law, 105 HARV. L. REV. 1437, 1509 (1992). 
TABLE 2

Summary Statistics for the Complete Sample

\begin{tabular}{|c|c|c|c|c|c|}
\hline & $\begin{array}{c}\text { Mean or } \% \\
\text { positive }\end{array}$ & Median & St. dev. & Min & Max \\
\hline \multicolumn{6}{|l|}{ Panel A: Company Headquarters } \\
\hline California & $27 \%$ & -- & -- & 0 & 1 \\
\hline Massachusetts & $6 \%$ & -- & -- & 0 & 1 \\
\hline New York & $4 \%$ & -- & -- & 0 & 1 \\
\hline Texas & $10 \%$ & -- & -- & 0 & 1 \\
\hline \multicolumn{6}{|l|}{ Panel B: Company Industry } \\
\hline High Tech & $42 \%$ & -- & -- & 0 & 1 \\
\hline Software & $23 \%$ & -- & -- & 0 & 1 \\
\hline Medical & $3 \%$ & -- & -- & 0 & 1 \\
\hline M\&A in Industry & 37.38 & 12 & 45.04 & 0 & 156 \\
\hline \multicolumn{6}{|c|}{ Panel C: Company Size and Offering Information } \\
\hline Assets ( $\$ \mathrm{M}$ before offering) & 1893.5 & 184.2 & 9304.3 & 0.2 & 137238 \\
\hline Market Cap (\$M) & 1455.3 & 464.0 & 6024.0 & 31.6 & 81247.2 \\
\hline Percentage of shares sold in IPO & $31.82 \%$ & $27.66 \%$ & $19.84 \%$ & $17 \%$ & $100 \%$ \\
\hline $\begin{array}{l}\text { Primary offering as a percentage of } \\
\text { total offering }\end{array}$ & $77 \%$ & $88 \%$ & $29 \%$ & 0 & 1 \\
\hline NYSE Listed & $46 \%$ & -- & -- & 0 & 1 \\
\hline Spinoff & $8 \%$ & -- & -- & 0 & 1 \\
\hline Reverse LBO & $34 \%$ & -- & -- & 0 & 1 \\
\hline \multicolumn{6}{|l|}{ Panel D: Other Company Information } \\
\hline Company Age (years) & 16.6 & 10 & 21 & 0 & 157 \\
\hline Delaware Incorporated & $91 \%$ & -- & -- & 0 & 1 \\
\hline \multicolumn{6}{|l|}{ Panel E: Company Management } \\
\hline CEO is chairman & $45 \%$ & -- & -- & 0 & 1 \\
\hline CEO is founder & $36 \%$ & -- & -- & 0 & 1 \\
\hline CEO's age & 51.4 & 51.0 & 8.3 & 27 & 86 \\
\hline Insider Ownership & $50.0 \%$ & $53.3 \%$ & $32 \%$ & 0 & 100 \\
\hline \multicolumn{6}{|l|}{ Panel F: Issuer Law Firm } \\
\hline$\overline{\text { New York City law firm }}$ & $26 \%$ & -- & -- & 0 & 1 \\
\hline Silicon Valley law firm & $23 \%$ & -- & -- & 0 & 1 \\
\hline Law firm acquirer rep. (\#) & 18.2 & 12.0 & 19.7 & 0 & 80 \\
\hline Law firm target rep. (\#) & 22.6 & 17.0 & 22.1 & 0 & 105 \\
\hline \# of issuers represented & 7.6 & 6.0 & 6.7 & 1 & 23 \\
\hline Law firm size (\# lawyers) & 969.4 & 754.0 & 746.9 & 3 & 3805 \\
\hline \multicolumn{6}{|l|}{ Panel G: Financial Sponsors } \\
\hline Private Equity & $46 \%$ & -- & -- & 0 & 1 \\
\hline Venture Capital & $43 \%$ & -- & -- & 0 & 1 \\
\hline
\end{tabular}

Forty-two percent (42\%) of the companies are part of "high-tech" industries. Of the high-tech companies, 55\% are software companies. The software industry also had 
the most M\&A transactions in the three years leading up to an IPO, reaching a peak of 156 transactions. However, the median level of M\&A activity in an industry was only 12 transactions. In fact, $12.4 \%$ of the companies are in industries that had no M\&A activity prior to their IPOs.

On average, an issuer had $\$ 1.9$ billion in total assets before the offering. This is a sizeable increase from the average total assets after an offering of \$212 million reported by Daines and Klausner just ten years ago. ${ }^{* * * * * * * * * * * * * * * *}$ However, the total assets for individual companies varied markedly ( $\$ 9.3$ billion standard deviation), ranging from $\$ 200,000$ in assets for Ventrus Biosciences Inc. (VTUS) to over $\$ 137$ billion for General Motors Co. (GM). The average market capitalization before an offering ( $\$ 1.5$ billion) is also much higher than what was found in previous studies (\$211.7 million).

The median company issued shares constituting $88 \%$ of the offering - an almost identical amount to what was found ten years ago. ${ }^{+1+t+1+t+1+t+1+\dagger}$ The average percentage of total shares offered in an IPO is $31.8 \%$, also in line with what previous studies

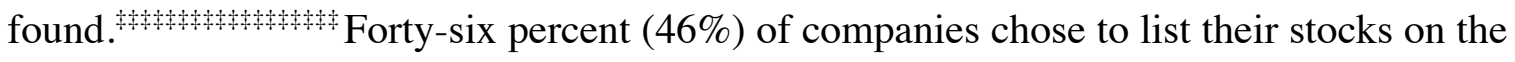
New York Stock Exchange. Almost all of the rest were listed on the NASDAQ

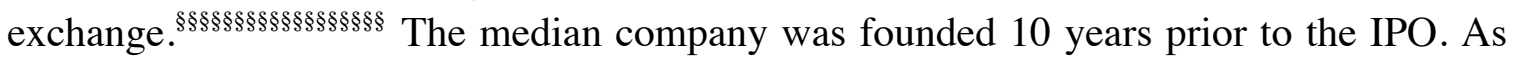
this is virtually unchanged from the median age of 9 years that Coates observes in the early 1990s, it does not appear that companies today are waiting longer before going public.

Eight percent $(8 \%)$ of the IPOs are spinoffs from corporate parents. A staggering $34 \%$ are reverse leveraged buyouts ("RLBO") - meaning that the IPO companies had previously been bought out and taken private by private equity investors.

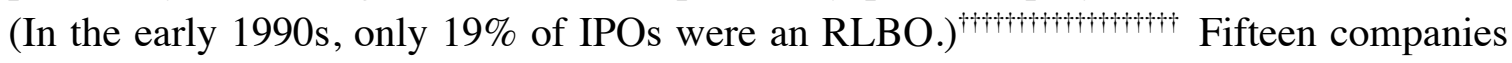
$(6 \%)$ have been acquired since their IPO, with the transactions completed in a mean of 22 months after the IPO.

\section{Issuer management.}

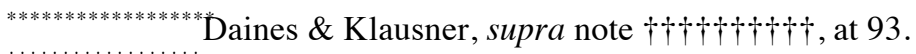

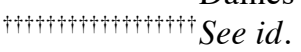

See id. (reporting that $35 \%$ of shares were sold, on average, in an IPO); Field \& Karpoff, supra note $* * * * * *$, at 1860 (reporting a mean of $32.5 \%$ and a median of $31.1 \%$ ).

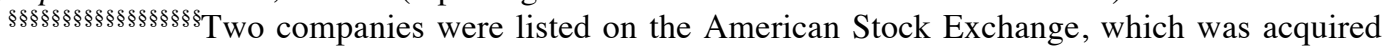
by the NYSE in 2008.

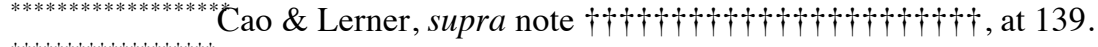

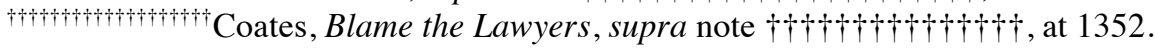

fost-IPO acquisition data is from FactSet's MergerMetrics database. As of Mar. 7 , 2013, acquisitions of another 6 companies in the sample have been announced but not yet completed.
} 
Panel E of Table 2presents data on the CEO and management of the sample companies. While the average CEO is fifty-one years old at the time of the IPO, there are some amusing outliers. The youngest CEO was Mark Zuckerberg, who took Facebook public when he was just twenty-seven years old. At the other end of the spectrum, Dole's CEO (David Murdock) was eighty-six at its IPO and has served in that position for over 24 years. In a little less than half (45\%) of the companies, the CEO also serves as chairman of the board. Additionally, around one third $(36 \%)$ of the CEOs are also

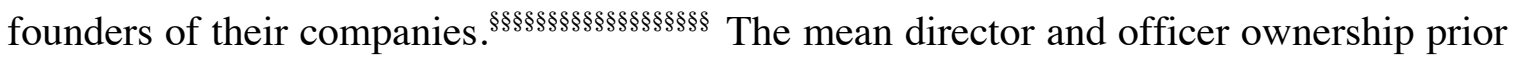
to the IPO is $50 \%$ but ranges from as little as $0 \%$ to as much as $100 \%$ of the shares.

\section{Law firms.}

The sample shows that the market for corporate legal services is not nearly as fragmented as it was twenty years ago. Two hundred and fifty nine (259) companies relied on 84 different law firms to serve as legal counsel for their IPOs. Even though this sample includes 100 more companies than the Coates early 1990s sample, it shows that 27 less law firms were used overall. . $^{* * * * * * * * * * * * * * * * * *}$ This likely is a result of consolidation

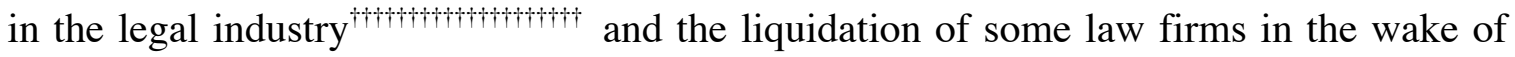

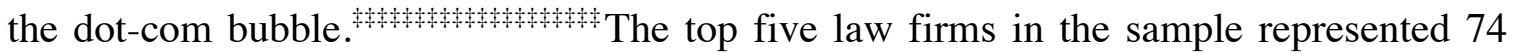
companies, accounting for $28.5 \%$ of the sample. This also reveals defragmentation in the legal market, as Coates found that the top ten law firms did not even account for one third

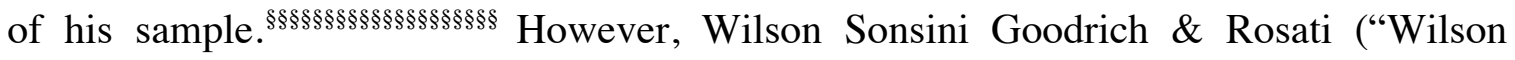
Sonsini") still captured more of the IPO market than any other law firm, representing 23 companies. ${ }^{* * * * * * * * * * * * * * * * * * *}$ A given law firm served as counsel for a mean of 7.6 IPOs.

Consistent with the consolidation of the legal industry, the number of lawyers employed by a given law firm has grown exponentially over the past twenty years. For the entire sample of IPOs, the mean size in 2012 is 969 lawyers and is as high as 3,805 lawyers (DLA Piper and Baker \& McKenzie both employ over 3,700 lawyers). This mean is larger than the number employed by all but two law firms in the 1990s

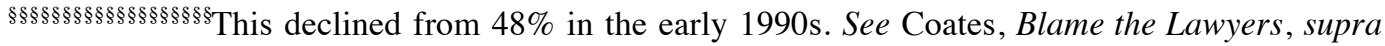
note $\uparrow+\uparrow+\uparrow+\uparrow+\uparrow+\uparrow+\uparrow+\dagger$, at 1352 .

*********************ee id. at 1354 (finding that 160 companies used 111 different law firms).

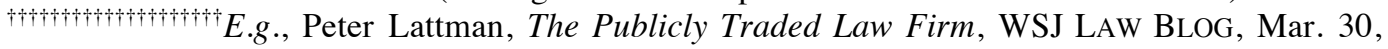
2007, http://blogs.wsj.com/law/2007/03/30/the-publicly-traded-law-firm-2/.

For example, Brobeck Phleger, a law firm that represented the third most IPO companies in the Coates study, was liquidate in 2003 after it lost money in the dot-com bubble. See Todd Wallack \& Harriet Chiang, Top S.F. dot-com law firm to close, S.F. CHRON., Jan. 31, 2003, http://www.sfgate.com/news/article/Top-S-F-dot-com-law-firm-to-close-Brobeck-2675897.php.

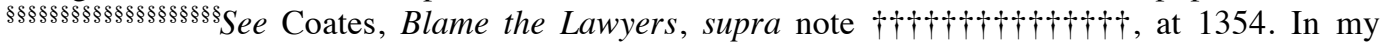
sample, the top seven law firms account for $36 \%$ of the IPOs. S See infra Table 3. 


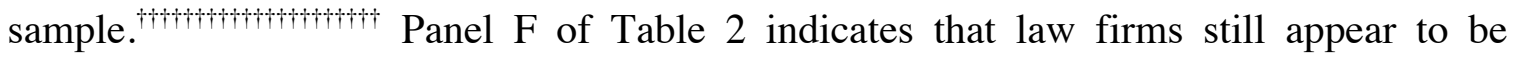
geographically concentrated. The IPO market share of New York City law firms has declined from $30 \%$ to $26 \%$ over the last twenty years while the market share of Silicon Valley law firms has increased fourfold from $6 \%$ to $23 \%$.

The public M\&A experience of the law firms in the sample varies considerably. The mean (22.6) and median (17) number of deals for which a law firm represented an M\&A target is larger than the respective mean (18.2) and median (12) number of acquirer representations. The overall M\&A experience for IPO counsel also fluctuates, ranging from no experience at all to Skadden's participation in $185 \mathrm{M} \& \mathrm{~A}$ transactions in the three years prior to some IPOs. transactions, the overall M\&A indices are not skewed by any one firm's activity.

\section{4. $\quad$ Private equity and venture capital.}

As indicated in Panel $\mathrm{G}$, private equity firms back $46 \%$ of companies in the sample, while venture capital firms back $43 \%$ of the companies at the time of their

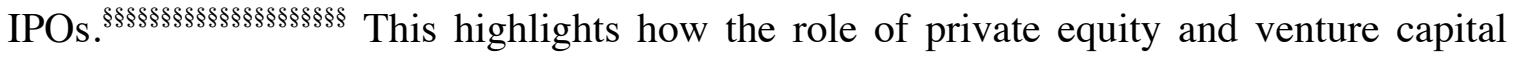
funds in the IPO market has increased over the past decade. In the late 1990s, only $29 \%$ of IPOs were backed by private equity funds, ${ }^{* * * * * * * * * * * * * * * * * * * * *}$ and throughout that entire decade, the frequency of venture capital backing remained unchanged at $34 \%$.

\section{Takeover defenses.}

Of the 259 IPOs in the sample, $97.3 \%$ of companies are able to adopt a "morningafter" poison pill should a takeover threat emerge. All but five companies are authorized to issue blank check preferred stock while two companies have "anti-poison pill" provisions, which prohibit the adoption of a poison pill without prior stockholder approval, in their charters. Such explicit anti-takeover provisions are extremely rare and

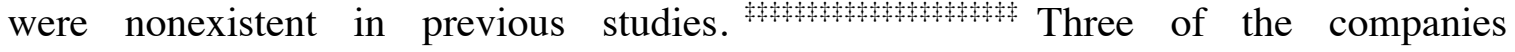
incorporated in Delaware (1\%) have expanded constituency provisions that allow

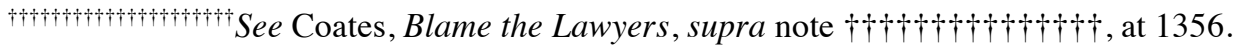

Coincidentally, Skadden worked on an almost identical number of transactions (185) in the Coates study. See id. at 1355.

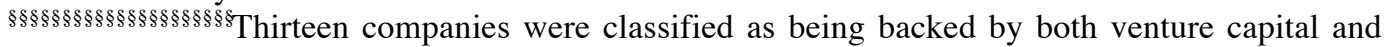
private equity firms.

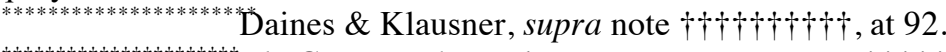

 the early 1990s).

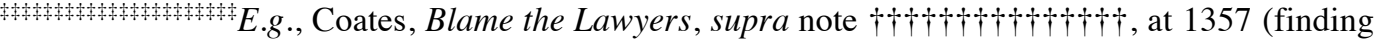
that no company explicitly prohibited a poison pill); Daines \& Klausner, supra note $\dagger+\uparrow \dagger+\uparrow \dagger+\dagger \dagger$, at 95 (finding that no firm limited the authority of management to adopt a poison pill). 
directors to consider non-shareholder constituencies when evaluating takeover

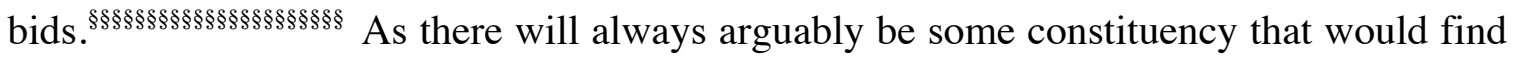
a takeover to be detrimental, Daines and Klausner convincingly note that these provisions give management "expansive authority to resist a hostile bid that would benefit shareholders.,${ }^{* * * * * * * * * * * * * * * * * * * * * * * * *}$ Sixteen percent (16\%) of the sample companies have dual class structures. While Coates observed that the frequency of dual class capital structures declined from $11 \%$ of IPOs in 1992 to $6 \%$ in 1999, it appears that the trend has

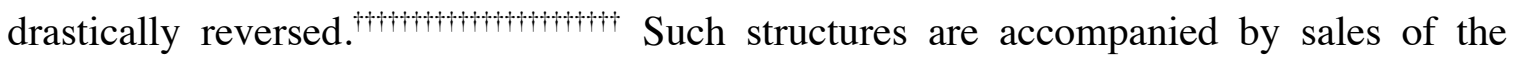
class of stock with lower (or no) votes in ten $(9 \%)$ of the IPOs, virtually the same percentage as in the sample from the early 1990s (8\%).

As previously discussed, pre-IPO decisions on takeover defenses are crucial because it is almost impossible for a public company to adopt takeover defenses such as a classified board once it goes public. Moreover, institutional shareholders have increased their efforts to declassify the boards of public companies and have been extremely

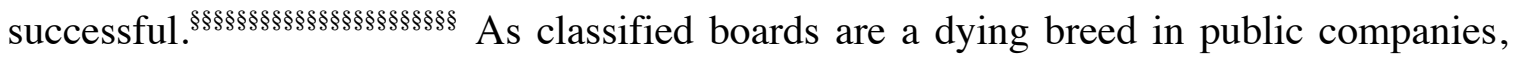
and as companies therefore know that they will likely face pressure to declassify once public, it is worth considering whether firms are increasingly adopting a potent substitute takeover defense-dual class stock with unequal voting rights - in lieu of a classified board.

\section{Figure 2}

Dual Class Structures by Year

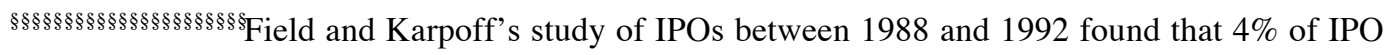
firms included such a provision. Field \& Karpoff, supra note ******, at 1861.

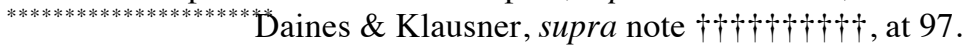

See Coates, Blame the Lawyers, supra note $+\uparrow+\uparrow+\uparrow+\dagger+\dagger+\dagger+\dagger$, at 1353.

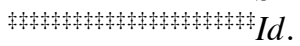

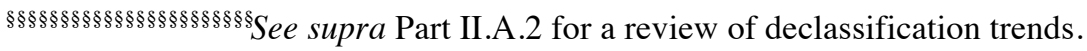




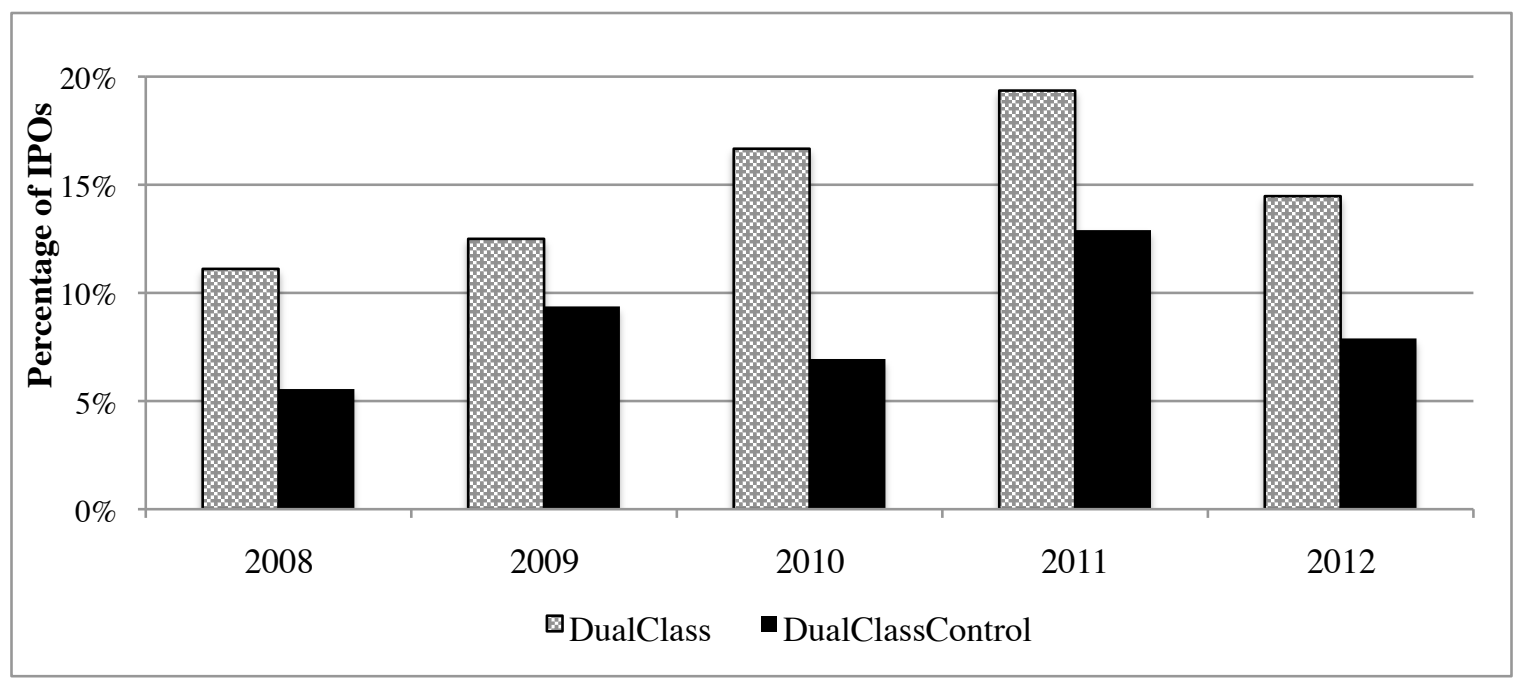

Figure 2 illustrates that the use of dual class stock has generally increased from 2008 to 2012. However, the increase is rather small compared to what one would expect if dual class control structures were being used to substitute for classified boards. 
Figure 3

Percentage of IPOs with Classified Boards

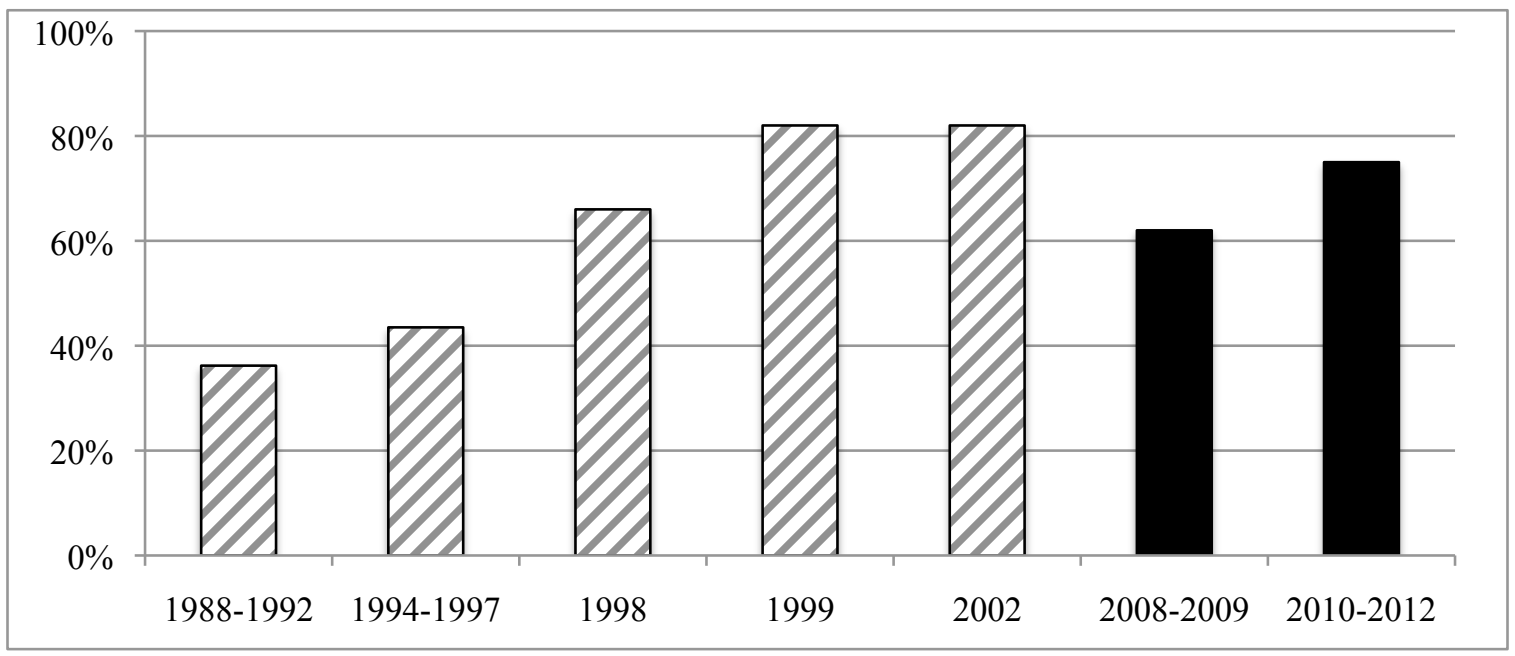

Out of the 237 firms in the sample that are not subject to low-vote dual class structures, 177 (75\%) have a classified board. As illustrated in Figure 3, there has been a drastic increase the use of classified boards as only $36 \%$ of IPOs in the early 1990s and $44 \%$ of IPOs in 1994 to 1997 included a classified board. This evidence is generally consistent with Bebchuk's hypothesis that lawyers recommend takeover defenses because it produces the smallest likelihood that their clients would complain about the legal

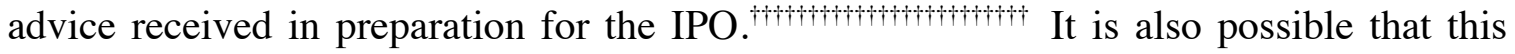
massive increase the incidence of classification is an unintended result of staunch shareholder opposition to the adoption of takeover defenses in already-public companies. Because managers know that their shareholders will never approve defenses mid-stream, they may seek to include defenses such as a classified board at the IPO. In fact, two companies in the sample (SPS Commerce and Visa) that went public with classified boards have since successfully brought management proposals to declassify their boards. Nevertheless, it is apparent that the prevalence of classified boards peaked at over $82 \%$ between 1999 and 2002 and has somewhat receded since then. As Bebchuk's hypothesis does not predict such a decline, it cannot fully explain the trend.

Of the 177 classified boards, only 149 (63\% of the sample) can be considered "effective." This is because 28 companies had mechanisms in place that would render any classified board illusory, such as provisions allowing shareholders to pack the board,

1988-92 data is from Field \& Karpoff, supra note ******, at 1858. 1994-97 data is from Daines \& Klausner, supra note $\uparrow \uparrow \uparrow+\uparrow \dagger+\uparrow \dagger \dagger$, at 96. 1998-99 data is from Coates, Blame the Lawyers, supra note $+\uparrow+\uparrow+\uparrow+\dagger+\dagger+\dagger+\dagger \dagger$, at 1376-77. A missing column indicates that data was not available. 2002 data is from Joanne Allegra, SharkRepellent.net, IPO Year in Review 2002 (Jan. 6, 2003), http://www.sharkrepellent.net/pub/rs_20030106.shtml.

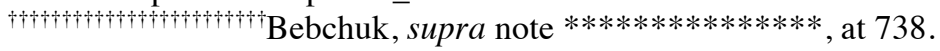


to remove directors without cause with a simple majority vote, or because the classification only exists in the bylaws.

\section{B. Mean Comparisons and Univariate Regressions}

1. Law firm identity and $M \& A$ experience.

The identity of issuer counsel appears to affect takeover defenses, consistent with the Coates study. ESBs, and dual stock control structures in IPO companies advised by the top 20 law firms (ranked by the number of times they appeared as counsel in the sample). Companies advised by 5 law firms - Wilson Sonsini, Gunderson Dettmer, Gibson Dunn, Davis Polk, and Vinson \& Elkins - went public with a classified board $100 \%$ of the time. This contrasts with the Coates finding that firms advised by Wilson Sonsini in the early 1990s almost never had a classified board, and by the end of the decade, only $25 \%$ of their

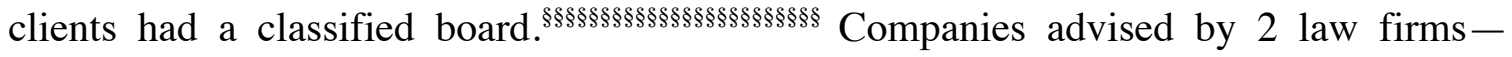
Gunderson Dettmer and Davis Polk - even had an effective staggered board $100 \%$ of the time while 6 other law firms took at least $80 \%$ of clients public with an ESB. While all of the companies advised by Vinson \& Elkins went public with a classified board, none of those boards were effectively classified. On the other end of the spectrum, no client of Akin Gump in the sample went public with a classified board or a dual class control structure.

Certain law firms that predominantly represent targets in public M\&A transactions, such as Wilson Sonsini, WilmerHale, and Goodwin Procter, almost always install effective staggered boards in IPO clients. In contrast, issuers using law firms Simpson Thacher, Kirkland \& Ellis, and Weil Gotshal-that primarily represent M\&A acquirers appear to adopt ESBs less often. It is worth noting that with one exceptionGunderson Dettmer, which only worked on 1 M\&A transaction-law firms in the sample have much more M\&A experience than they did in the early 1990s. For example, the IPO leader, Wilson Sonsini, had worked on average of 45 total M\&A transactions in the three years prior to an IPO in the sample versus only 12 transactions in the Coates study.

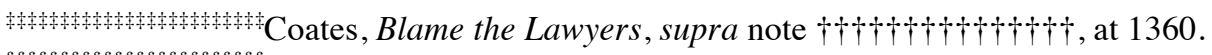

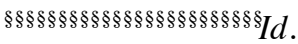

Id. at 1356. 
TABLE 3

Defenses by Top Law Firms (by \# of IPOs)

\begin{tabular}{|c|c|c|c|c|c|c|c|c|c|c|}
\hline \multirow[b]{2}{*}{ Issuer Law Firm } & \multirow[b]{2}{*}{$\begin{array}{c}\text { Law Firm } \\
\text { HQ }\end{array}$} & \multirow[b]{2}{*}{ IPOs } & \multicolumn{4}{|c|}{ Client Takeover Defenses } & \multicolumn{2}{|c|}{ M\&A } & \multicolumn{2}{|c|}{ Backing } \\
\hline & & & $\begin{array}{l}\text { 島 } \\
\text { 至 } \\
\text { 岕 } \\
\text { 己 }\end{array}$ & $\begin{array}{l}\text { صै } \\
\text { II }\end{array}$ & 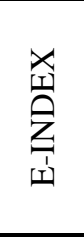 & 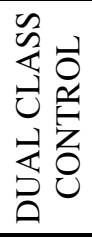 & 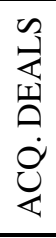 & 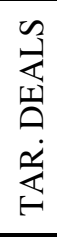 & 咅 & $\stackrel{\cup}{>}$ \\
\hline Wilson Sonsini & Palo Alto & 23 & $100 \%$ & $91 \%$ & 3.78 & $9 \%$ & 13 & 32 & $17 \%$ & $91 \%$ \\
\hline Latham \& Watkins & New York & 18 & $89 \%$ & $72 \%$ & 3.50 & $11 \%$ & 63 & 73 & $47 \%$ & $53 \%$ \\
\hline Cooley & Palo Alto & 12 & $75 \%$ & $75 \%$ & 3.50 & $8 \%$ & 12 & 19 & $0 \%$ & $83 \%$ \\
\hline Kirkland \& Ellis & Chicago & 11 & $55 \%$ & $45 \%$ & 3.00 & $0 \%$ & 34 & 21 & $91 \%$ & $18 \%$ \\
\hline WilmerHale & D.C. & 11 & $91 \%$ & $91 \%$ & 3.73 & $18 \%$ & 5 & 17 & $36 \%$ & $55 \%$ \\
\hline Simpson Thacher & New York & 10 & $50 \%$ & $20 \%$ & 2.00 & $0 \%$ & 45 & 36 & $100 \%$ & $0 \%$ \\
\hline Fenwick \& West & $\begin{array}{l}\text { Mountain } \\
\text { View }\end{array}$ & 9 & $78 \%$ & $78 \%$ & 3.33 & $33 \%$ & 5 & 13 & $11 \%$ & $100 \%$ \\
\hline Goodwin Procter & Boston & 9 & $89 \%$ & $89 \%$ & 3.78 & $0 \%$ & 11 & 11 & $33 \%$ & $100 \%$ \\
\hline Pillsbury Winthrop & $\begin{array}{l}\text { San } \\
\text { Francisco }\end{array}$ & 8 & $63 \%$ & $63 \%$ & 3.13 & $0 \%$ & 3 & 13 & $38 \%$ & $63 \%$ \\
\hline Skadden & New York & 8 & $63 \%$ & $50 \%$ & 2.63 & $13 \%$ & 66 & 82 & $75 \%$ & $0 \%$ \\
\hline DLA Piper & New York & 7 & $86 \%$ & $86 \%$ & 3.86 & $0 \%$ & 15 & 20 & $57 \%$ & $57 \%$ \\
\hline Gunderson Dettmer & Menlo Park & 6 & $100 \%$ & $100 \%$ & 4.00 & $0 \%$ & 1 & 0 & $0 \%$ & $100 \%$ \\
\hline Wachtell Lipton & New York & 6 & $83 \%$ & $67 \%$ & 2.50 & $0 \%$ & 25 & 33 & $83 \%$ & $0 \%$ \\
\hline Gibson Dunn & Los Angeles & 5 & $100 \%$ & $80 \%$ & 3.80 & $0 \%$ & 20 & 41 & $60 \%$ & $20 \%$ \\
\hline Ropes \& Gray & Boston & 5 & $80 \%$ & $80 \%$ & 3.60 & $20 \%$ & 16 & 13 & $60 \%$ & $40 \%$ \\
\hline Weil Gotshal & New York & 5 & $40 \%$ & $40 \%$ & 2.20 & $0 \%$ & 40 & 28 & $100 \%$ & $0 \%$ \\
\hline Davis Polk & New York & 4 & $100 \%$ & $100 \%$ & 3.75 & $25 \%$ & 36 & 32 & $25 \%$ & $50 \%$ \\
\hline Vinson \& Elkins & Houston & 4 & $100 \%$ & $0 \%$ & 3.25 & $0 \%$ & 14 & 11 & $100 \%$ & $0 \%$ \\
\hline Akin Gump & D.C. & 3 & $0 \%$ & $0 \%$ & 2.33 & $0 \%$ & 6 & 10 & $67 \%$ & $0 \%$ \\
\hline Cravath & New York & 3 & $33 \%$ & $0 \%$ & 1.33 & $33 \%$ & 34 & 33 & $0 \%$ & $0 \%$ \\
\hline
\end{tabular}

Some law firms also appear to have strong relationships with certain types of financial sponsors. One hundred percent (100\%) of the IPO clients of Simpson Thacher, Weil Gotshal, and Davis Polk and $91 \%$ of the clients of Kirkland \& Ellis were backed by private equity funds. Similarly, $100 \%$ of the IPO clients of Fenwick \& West, Goodwin Procter, and Gunderson Dettmer and 91\% of the clients of Wilson Sonsini were backed by venture capital funds. 
TABLE 4

ESB Incidence by Law Firm's M\&A Role

Law Firm

Acquirer M\&A

Experience

\begin{tabular}{l|c|c|c}
\multirow{2}{*}{} & \multicolumn{3}{|c}{ Law Firm Target M\&A Experience } \\
& $\mathrm{Q}_{1}$ & IQR & $\mathrm{Q}_{3}$ \\
\hline $\mathrm{Q}_{1}$ & $49 \%$ & $71 \%$ & -- \\
& $(\mathrm{n}=43)$ & $(\mathrm{n}=7)$ & $82 \%$ \\
\hline $\mathrm{IQR}$ & $67 \%$ & $70 \%$ & $(\mathrm{n}=17)$ \\
& $(\mathrm{n}=12)$ & $(\mathrm{n}=100)$ & $54 \%$ \\
$\mathrm{Q}_{3}$ & - & $52 \%$ & $(\mathrm{n}=37)$ \\
& & $(\mathrm{n}=21)$ & \\
\hline
\end{tabular}

Note: Firms with dual class capital structures in which lower or no vote stock is sold (Dual Class Control=1) are excluded from this table.

Law firms' experience in specific roles in M\&A transactions also appears to help explain the variance in the adoption of effective staggered boards in Table 4. After holding acquirer-side experience constant, ESB incidence increases as law firms' targetside M\&A experience (Law Target Deals) increases. And after holding target-side experience constant, acquirer-side M\&A experience (Law Acquirer Deals) is generally associated with a decrease in ESB incidence. This result supports the Law Firm Role hypothesis, which predicted that a law firm's type of M\&A experience would influence whether or not it advises IPO companies to adopt takeover defenses.

\section{Law firm location and PE/VC backing.}

Almost half (45\%) of private equity-backed companies used a New York City law firm as legal counsel for their IPOs. On the other end of the spectrum, half $(51 \%)$ of the venture capital-backed companies used a Silicon Valley law firm. PE-backed issuers' legal counsel had represented 24.3 acquirers and 25.7 targets in M\&A transactions on average, while VC-backed issuers' legal counsel had only represented an average of 13.7 acquirers and 21.6 targets. However, only the difference in acquirer representation is statistically significant.

\section{TABLE 5}

ESB Incidence by New York Law Firms \& PE Backing

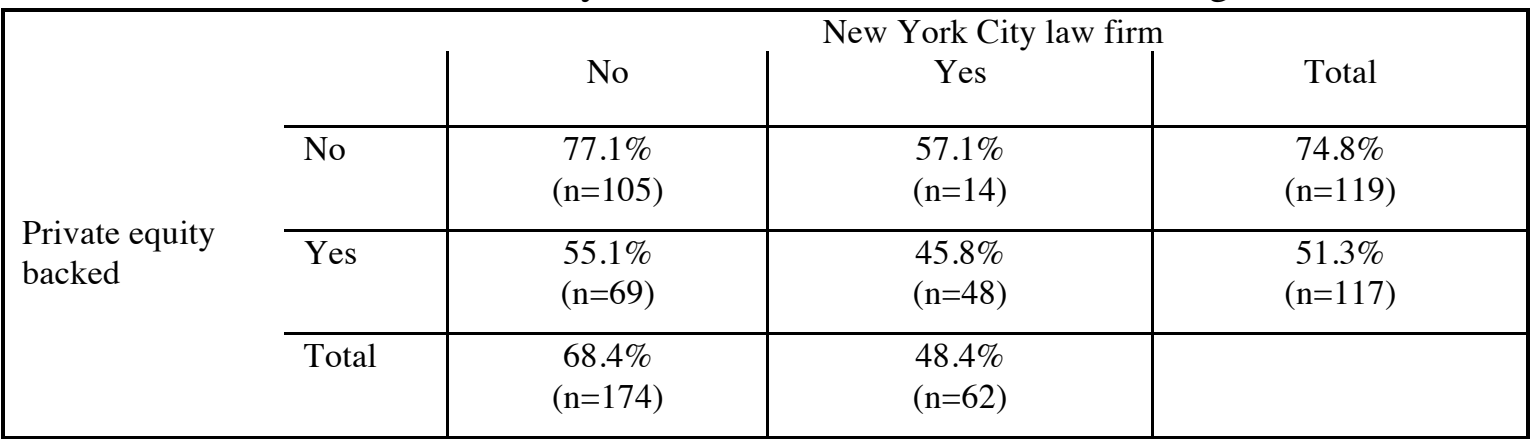


Note: Firms with dual class capital structures in which lower or no vote stock is sold (Dual Class Control=1) are excluded from this table.

Table 5 shows that companies using a New York City law firm as legal counsel and companies backed by private equity funds are both less likely to have an effective staggered board than other companies. While issuers using a New York City law firm and private equity backed issuers had the lowest incidence of ESBs, the interaction effect of the variables is not statistically significant.

Consistent with Coates, Silicon Valley law firms are no longer negatively correlated with classified boards. In fact, $87 \%$ of the 60 Silicon-Valley-law-firm-advised companies have effective staggered boards, a higher percentage than the other firms $(53 \%, p<.001)$. Initially, this appears to support the Silicon Valley Effect hypothesis and indicates that there is a positive correlation between takeover defenses and Silicon Valley law firms. As shown in Table 6, there is large overlap between Silicon Valley law firms and venture capital-backed firms (there is a 0.5 correlation) and the number of non-VCbacked firms in the sample not using a Silicon Valley law firm $(n=7)$ is extremely small. As a result, it is almost impossible to disentangle their collinear relationships with board classification in this table.

Coates found that, in a sample of IPOs from 1991-92, Silicon-Valley-lawyeradvised firms had classified boards only $11 \%$ of the time, well below the sample average $(34 \%, p<.001)$, but by 1998-99, Silicon-Valley-lawyer-advised firms had classified boards $50 \%$ of the time, statistically equivalent to other firms in the

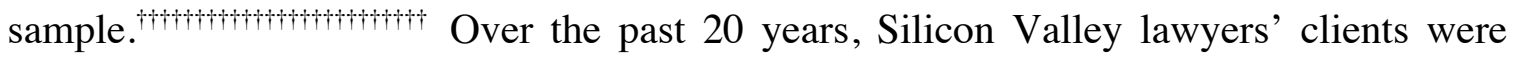
associated with a steadily increasing use of classified boards, topping out at nearly $92 \%$ in 2010, outpacing the general increase in classified board incidence in IPOs over that period. Given the criticism directed at such firms for not using classified boards in the earlier period, it would not be a stretch to see an instance of over-correction in a movement from $11 \%$ to $50 \%$ to $92 \%$. In any event, these results confirm there was likely never a client-based reason not to use classified boards in IPOs in the early 1990s, and that instead their scarcity in that period was due to inattention on the lawyers' part in that period.

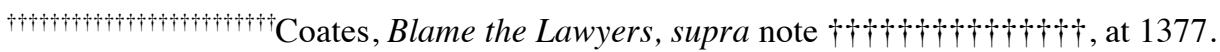


TABLE 6

ESB Incidence by Silicon Valley Law Firms and VC Backing

Venture capital

backed

\begin{tabular}{l|c|c|c|} 
& \multirow{2}{*}{ No } & Silicon Valley law firm & Total \\
\hline No & $41.9 \%$ & $71.4 \%$ & $43.4 \%$ \\
& $(\mathrm{n}=129)$ & $(\mathrm{n}=7)$ & $(\mathrm{n}=136)$ \\
\hline Yes & $86.8 \%$ & $93.6 \%$ & $90 \%$ \\
& $(\mathrm{n}=53)$ & $(\mathrm{n}=47)$ & $(\mathrm{n}=100)$ \\
\hline Total & $54.9 \%$ & $90.7 \%$ & \\
& $(\mathrm{n}=182)$ & $(\mathrm{n}=54)$ & \\
\hline
\end{tabular}

Note: Firms with dual class capital structures in which lower or no vote stock is sold (Dual Class

Control=1) are excluded from this table.

\section{Takeover defenses and PE/VC backing.}

Table 7 summarizes the incidence of numerous takeover defenses in the sample and in subsamples for venture capital and private equity backed companies. While only $9 \%$ of companies in the complete sample had dual class stock and issued common stock with lower (or no) voting rights (DualClassControl=1), a full $12 \%$ of venture capitalbacked companies issued such stock. It is apparent that the central purpose of dual class stock issued by venture-backed companies was to preserve voting control. The opposite result is found in private equity-backed IPOs. While a higher portion (16\%) of PE-backed companies had multiple classes of common stock, only 3\% of PE-backed companies issued low-/no-vote stock. Companies backed by neither private equity nor venture capital are the most likely to issue such stock. This is probably because this category includes family-run companies that wish to preserve control in the family-owners as Coates found in his 2001 study.

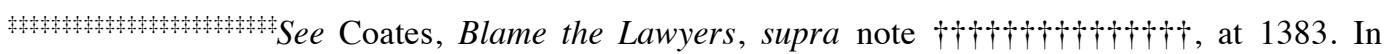
other words, the non-pecuniary private benefits of control are likely higher in family-run companies. 
TABLE 7

Takeover Defense Frequency with VC \& PE Subsamples

\begin{tabular}{|c|c|c|c|c|}
\hline Type of takeover defense & Full sample & $\begin{array}{c}\text { VC } \\
\text { subsample }\end{array}$ & $\begin{array}{c}\text { PE } \\
\text { subsample }\end{array}$ & $\begin{array}{c}t \text {-statistic for } \\
\text { difference } \\
\text { subsample means }\end{array}$ \\
\hline Classified board & $72 \%$ & $87 \%$ & $66 \%$ & $3.59 * * *$ \\
\hline Effective Staggered Board (ESB) & $60 \%$ & $84 \%$ & $47 \%$ & $6.08 * * *$ \\
\hline E-Index & 3.0 & 3.6 & 2.8 & $6.10 * * *$ \\
\hline Dual-class stock & $16 \%$ & $12 \%$ & $16 \%$ & -0.78 \\
\hline $\begin{array}{l}\text { Dual-class stock with unequal voting } \\
\text { rights }\end{array}$ & $9 \%$ & $12 \%$ & $3 \%$ & $2.54 * *$ \\
\hline Implicit ban on poison pill & $2.7 \%$ & $2 \%$ & $2 \%$ & 0.08 \\
\hline Anti-poison pill provision & $1 \%$ & $1 \%$ & $0 \%$ & 1.00 \\
\hline Blank check preferred stock & $98 \%$ & $99 \%$ & $98 \%$ & 0.52 \\
\hline Expanded constituency provision & $1 \%$ & $1 \%$ & $2 \%$ & -0.52 \\
\hline Fair price provision & $0 \%$ & $0 \%$ & $1 \%$ & -1.00 \\
\hline Board authorized to increase board size & $99 \%$ & $100 \%$ & $99 \%$ & 1.00 \\
\hline Shareholders can act by written consent & $24 \%$ & $4 \%$ & $46 \%$ & $-7.98 * * *$ \\
\hline Shareholders can call a special meeting & $23 \%$ & $7 \%$ & $33 \%$ & $-4.89 * * *$ \\
\hline $\begin{array}{l}\text { Supermajority requirement to amend } \\
\text { bylaws }\end{array}$ & $65 \%$ & $88 \%$ & $53 \%$ & $5.90 * * *$ \\
\hline $\begin{array}{l}\text { Supermajority requirement to amend } \\
\text { charter }\end{array}$ & $66 \%$ & $89 \%$ & $56 \%$ & $5.69 * * *$ \\
\hline Supermajority requirement for mergers & $2 \%$ & $0 \%$ & $3 \%$ & $-1.75^{*}$ \\
\hline$N$ & 259 & 99 & 107 & \\
\hline \multicolumn{5}{|c|}{${ }^{*} p<0.10,{ }^{* *} p<0.05,{ }^{* * *} p<0.01$ based on a two-tailed test. } \\
\hline
\end{tabular}

As shown in Figure 4, the frequency of classified boards in venture capital-backed IPOs has doubled since the mid-1990s, where they were only present $43 \%$ of the time, to $87 \%$. Likewise, the frequency of classified boards in private equity-backed IPOs has increased from $47 \%$ to $66 \%$. However, this increase is not as nearly as dramatic as the increase for venture capital-backed IPOs and is smaller than the overall increase in classification over the same time period. The difference in mean classification for venture capital- and private equity-backed issuers is statistically significant at the $1 \%$ level. The percentage of the 13 companies backed by both private equity and venture capital funds with a classified board is an astonishingly high 93\%. The incidence of board classification in companies not backed by either a venture capital or private equity firm has slightly increased from $41 \%$ in 1997 to $46 \%$ in the current sample. 
FigURE 4

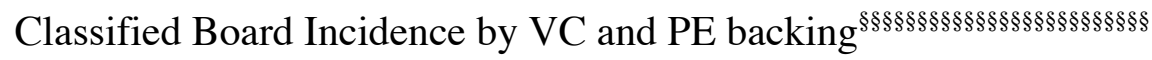

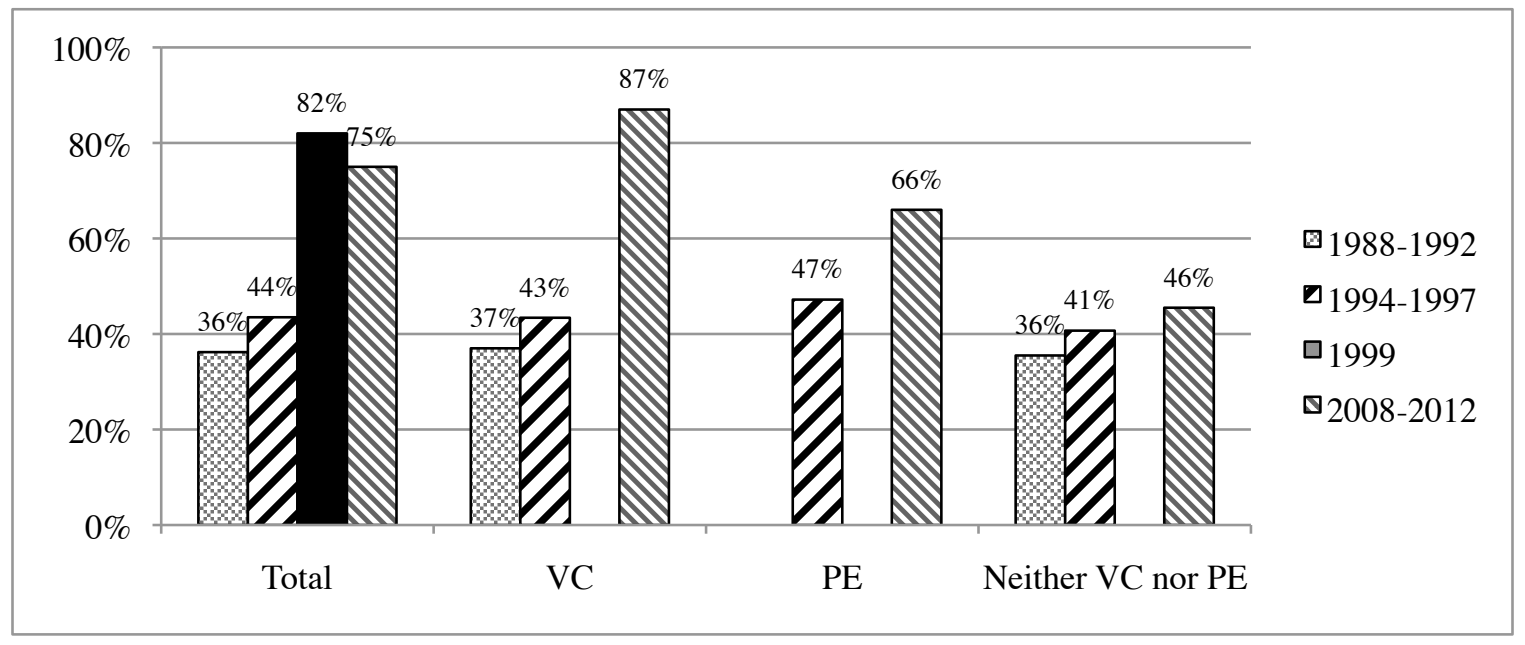

As noted in Part IV.A.4, venture capital and private equity firms back a substantial number of IPOs in the sample. Effective staggered board incidence by venture and private equity backing is summarized in Table 8 . Of issuers not subject to not subject to low-vote dual class structures, $90 \%$ of venture capital-backed companies had an effective staggered board. VC-backed firms are more likely to have effective classified boards, whether or not backed by PE-funds, and these differences are statistically significant. Meanwhile, only $51 \%$ of private equity-backed companies had an ESB at their IPO. This is substantially lower than the incidence of ESBs at non-private equitybacked companies $(75 \%)$. Finally, companies that are not backed by private equity or venture capital funds have the lowest incidence of ESBs (31.3\%).

TABLE 8

ESB Incidence by VC \& PE Backing

\begin{tabular}{|c|c|c|c|c|}
\hline \multirow{5}{*}{$\begin{array}{l}\text { Private equity } \\
\text { backed }\end{array}$} & & \multicolumn{3}{|c|}{ Venture capital backed } \\
\hline & & No & Yes & Total \\
\hline & No & $\begin{array}{l}31.3 \% \\
(\mathrm{n}=32)\end{array}$ & $\begin{array}{l}90.8 \% \\
(\mathrm{n}=87)\end{array}$ & $\begin{array}{l}74.8 \% \\
(\mathrm{n}=119)\end{array}$ \\
\hline & Yes & $\begin{array}{c}47.1 \% \\
(n=104)\end{array}$ & $\begin{array}{l}84.6 \% \\
(\mathrm{n}=13)\end{array}$ & $\begin{array}{l}51.3 \% \\
(n=117)\end{array}$ \\
\hline & Total & $\begin{array}{c}43.4 \% \\
(n=136)\end{array}$ & $\begin{array}{c}90.0 \% \\
(\mathrm{n}=100)\end{array}$ & \\
\hline
\end{tabular}

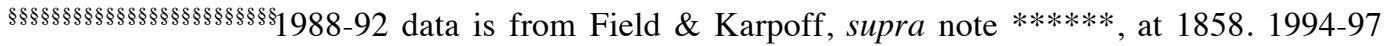
data is from Daines \& Klausner, supra note $\dagger+\dagger+\uparrow \dagger+\dagger \dagger \dagger$, at 96. 1998-99 data is from Coates, Blame the Lawyers, supra note $+\uparrow \dagger+\uparrow \dagger+\dagger+\dagger+\dagger \dagger \dagger$, at 1376-77. Companies with a dual stock control structure are excluded from the 1999 and 2008-12 calculations. A missing column indicates that data was not available. 
Table 7 also provides a breakdown of the frequency of the use of specific takeover defenses and corporate governance provisions at private equity and venture capital-backed companies. PE-backed issuers were much more likely than VC-backed issuers to include provisions that allow shareholders to act by written consent $(46 \%$ of PE-backed firms allow it versus only $4 \%$ of VC-backed firms) and to call a special meeting (33\% PE versus 7\% VC). The difference in both of these means is statistically significant. (Meanwhile, 28\% of companies in the S\&P 500 allow action by written consent and $53 \%$ allow shareholders to call special meetings. ${ }^{* * * * * * * * * * * * * * * * * * * * * * * * * * *}$ ) Shareholder action by written consent can actually help facilitate takeovers by permitting shareholders to accomplish the amendment of bylaws, removal of directors, filling of board vacancies, and other actions that can otherwise only be taken at a meeting of

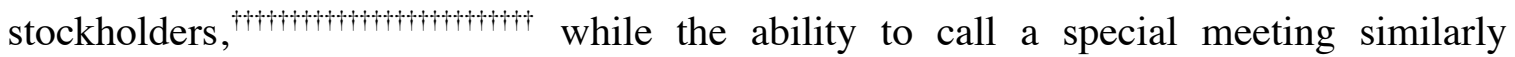
allows shareholders to take such actions without having to wait for the annual meeting. However, the motive of private equity firms that include such provisions in portfolio companies may be less innocuous than it seems. Instead, PE-backed companies likely allow action by written consent and special meetings in order to allow their private equity investors to take such actions. In fact, at least one law firm (Davis Polk) recommends that financial sponsors include these provisions so that they could "maximize [their]

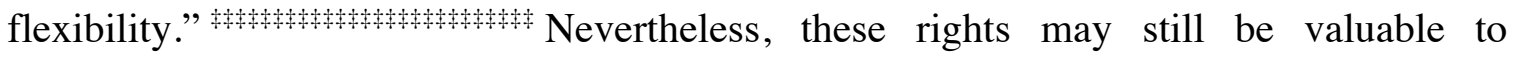
shareholders once financial sponsors sell their stakes.

While the ability to act by written consent or call a special meeting can facilitate shareholders' rights, supermajority provisions inhibit action by shareholders. An extremely large proportion (88\%) of venture capital-backed companies has supermajority requirements to amend the corporate charter or bylaws and slightly more than half of PEbacked companies have such provisions. In comparison, only $44 \%$ of S\&P 500 companies have a supermajority requirement to amend the charter and only $31 \%$ require

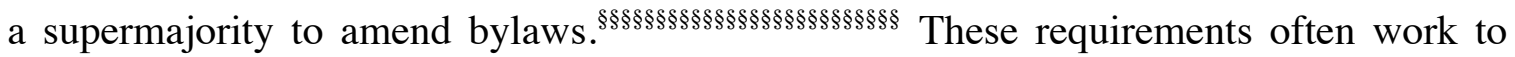
the detriment of shareholders and essentially give financial sponsors veto rights over charter and bylaw amendments.

\footnotetext{
**ased upon the number of eligible and active S\&P 500 companies in the SharkRepellent.net database as of Feb. 28, 2013.

 Klingsberg, Action by Written Consent: A New Focus for Shareholder Activism, HARV. LAW SCHOOL FORUM ON CORP. GOV. \& FIN. REG., July 5, 2010, http://blogs.law.harvard .edu/corpgov/2010/07/05/actionby-written-consent-a-new-focus-for-shareholder-activism/.

Davis Polk \& Wardwell, Post-IPO Charter Provisions for Portfolio

Companies (Private Equity Newsletter, Feb. 2006), available at http://www.davispolk.com/1485409/dpw/02_16_06_PrivateEquityNews_feb_06.pdf.

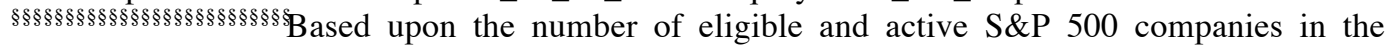
SharkRepellent.net database as of Feb. 28, 2013.
} 
The incidence of anti-takeover provisions such as unequal voting rights, classified boards, limitations on shareholder action by written consent or special meeting, and supermajority requirements in companies backed by venture capital and private equity firms is generally consistent with the PE/VC Private Benefits hypothesis. While private equity-backed companies, on average, do not have as strong takeover defenses as venture capital-backed companies, they still have a higher incidence of defenses as compared to public companies. The one exception observed is that private equity-backed companies are more likely to allow action by written consent and special meetings than VC-backed and S\&P 500 companies. However, this anomaly may be explained by the desire of private equity firms to maintain maximum flexibility while they still have high ownership stakes.

\section{PE/VC backing and issuer characteristics.}

Table 9 illustrates the different characteristics of companies and their IPOs of issuers backed by venture capital firms and issuers backed by private equity firms. Fiftythree percent $(53 \%)$ of VC-backed issuers have their headquarters in California while only $9 \%$ of PE-backed companies were based in California. On the other hand, more PEbacked companies (15\%) were based out of Texas $(15 \%)$ than VC-backed companies $(6 \%)$.

Unsurprising given the popular perception of the venture capital industry, $72 \%$ of VC-backed companies were in high tech industries. This is in stark contrast to the $21 \%$ of PE-backed companies in high tech industries. VC-backed companies also are in industries with a mean of $62.5 \mathrm{M} \& \mathrm{~A}$ transactions in the three years prior to the IPO (versus a mean of 17.6 for PE-backed companies). This number, however, is likely skewed by the number of VC-backed companies in the software industry (42\%), which, as mentioned in Part IV.A.1, had the highest level of M\&A activity.

Issuers sponsored by private equity firms had an average of almost $\$ 2$ billion more in assets at the time of the IPO. Nevertheless, there is no statistically significant difference in the pre-IPO market capitalization of VC- and PE-backed companies. While, on average, a larger percentage of the IPO was offered by the primary issuer in VCbacked IPOs (85\%) than in PE-backed IPOs $(71 \%)$, PE backed companies had a higher average IPO float (33\% versus $27.5 \%$ ).

The average PE-backed company was more than twice as old (20 years) than the average VC-backed company (9 years) at the IPO. As $66 \%$ of PE-backed IPOs were actually RLBOs, one would expect PE-backed companies to be older. While $43 \%$ of both VC- and PE-backed companies had a CEO-Chairman, more than half (54\%) of VCbacked companies had a founding CEO (whereas only $22 \%$ of PE-backed companies had 
a CEO founder). This may, in part, also be due to the difference in the mean age of PEand VC-backed companies.

TABle 9

Summary Statistics for VC and PE-backed Issuer Subsamples

\begin{tabular}{|c|c|c|c|c|}
\hline & $\begin{array}{c}\mathrm{VC} \\
\text { Mean or } \\
\text { percentage }\end{array}$ & $\begin{array}{c}\text { PE } \\
\text { Mean or } \\
\text { percentage }\end{array}$ & $\begin{array}{c}\text { Difference in } \\
\text { means }\end{array}$ & $\begin{array}{l}\text { t-statistic for } \\
\text { difference in } \\
\text { means }\end{array}$ \\
\hline \multicolumn{5}{|c|}{ Panel A: Company Headquarters } \\
\hline California & $53 \%$ & $9 \%$ & $43 \%$ & $7.47 * * *$ \\
\hline Massachusetts & $8 \%$ & $5 \%$ & $3 \%$ & 0.99 \\
\hline New York & $3 \%$ & $3 \%$ & $0 \%$ & 0.10 \\
\hline Texas & $6 \%$ & $15 \%$ & $-9 \%$ & $-2.11 * *$ \\
\hline \multicolumn{5}{|l|}{ Panel B: Company Industry } \\
\hline High Tech & $72 \%$ & $21 \%$ & $51 \%$ & $8.51 * * *$ \\
\hline Software & $42 \%$ & $8 \%$ & $34 \%$ & $5.99 * * *$ \\
\hline Medical & $4 \%$ & $2 \%$ & $2 \%$ & 0.91 \\
\hline M\&A in Industry & 62.5 & 17.6 & 44.9 & $7.90 * * *$ \\
\hline \multicolumn{5}{|c|}{ Panel C: Company Size and IPO } \\
\hline Assets ( $\$ M$ before offering) & 212.9 & 2124.8 & -1911.8 & $-4.15 * * *$ \\
\hline Market Cap (\$M) & 1611.9 & 1143.4 & 468.5 & 0.55 \\
\hline IPO Float & $27.5 \%$ & $33 \%$ & $-5.6 \%$ & $-2.21 * *$ \\
\hline$\%$ shares offered by issuer & $85 \%$ & $71 \%$ & $14 \%$ & $3.70 * * *$ \\
\hline NYSE Listed & $26 \%$ & $63 \%$ & $-36 \%$ & $-5.62 * * *$ \\
\hline Reverse LBO & $9 \%$ & $66 \%$ & $57 \%$ & $-10.54 * * *$ \\
\hline \multicolumn{5}{|c|}{ Panel D: Other Company Information } \\
\hline Company Age (years) & 9.1 & 20.1 & -11.8 & $-5.26 * * *$ \\
\hline Delaware Incorporated & $98 \%$ & $94 \%$ & $4 \%$ & 1.35 \\
\hline \multicolumn{5}{|c|}{ Panel E: Company Management } \\
\hline CEO is chairman & $43 \%$ & $43 \%$ & $0 \%$ & 0.06 \\
\hline $\mathrm{CEO}$ is founder & $54 \%$ & $22 \%$ & $31 \%$ & $4.81 * * *$ \\
\hline CEO's age & 48.8 & 53.1 & -4.5 & $-4.16 * * *$ \\
\hline Insider Ownership & $54.3 \%$ & $46.4 \%$ & $7.9 \%$ & $1.85^{*}$ \\
\hline \multicolumn{5}{|l|}{ Panel F: Issuer Law Firm } \\
\hline New York City law firm & $7 \%$ & $45 \%$ & $-38 \%$ & $-6.89 * * *$ \\
\hline Silicon Valley law firm & $51 \%$ & $6 \%$ & $45 \%$ & $8.13 * * *$ \\
\hline Law firm acquirer rep. (\#) & 13.7 & 24.3 & -10.6 & $-3.99 * * *$ \\
\hline Law firm target rep. (\#) & 21.6 & 25.7 & -4.1 & -1.34 \\
\hline \# of IPOs rep'd in sample & 10.4 & 6.08 & 4.3 & $4.72 * * *$ \\
\hline Law firm size (\# lawyers) & 877.7 & 1103.8 & -226.1 & $-2.25 * *$ \\
\hline$N$ & 99 & 107 & & \\
\hline
\end{tabular}

\section{Management characteristics.}


Table 10 displays the percentage of IPO companies with an effective staggered board broken down by CEO characteristics in companies without a dual class control structure. When companies are grouped together based on whether their CEO's age was above or below the mean CEO age, firms with CEOs 51 years old and younger have a much higher incidence (72\%) of effective classification than firms with CEOs that are 52 years and older $(53 \%)$. This result is statistically significant at the 5\% level. Companies with a founding CEO also had a higher incidence of ESBs (70\%) than other companies (60\%). However, this result is only significant at the $10 \%$ level. ESB incidence for the CEO-Chairman variable is not statistically significant. The CEO-Founder and CEO-Age results are consistent with the Management Entrenchment hypothesis. While not statistically significant, the result indicating that companies with a CEO-Chairman are less likely to have a classified board than a company that separates those roles is actually the opposite of what the Management Entrenchment hypothesis predicts.

TABLE 10

ESB Incidence by CEO Characteristics

\begin{tabular}{|c|c|c|c|c|}
\hline & Value & $\%$ with ESB & $\mathrm{n}$ & t-test \\
\hline \multirow{2}{*}{ CEO is chairman? } & Yes & $60.6 \%$ & 104 & \multirow{2}{*}{0.64} \\
\hline & No & $64.7 \%$ & 133 & \\
\hline \multirow{2}{*}{ CEO is founder? } & Yes & $70.0 \%$ & 80 & \multirow{2}{*}{$-1.6^{*}$} \\
\hline & No & $59.6 \%$ & 156 & \\
\hline \multirow{2}{*}{ CEO age? } & $<51.4$ years & $72.1 \%$ & 122 & \multirow{2}{*}{$3.1 * *$} \\
\hline & $>51.4$ years & $53.0 \%$ & 115 & \\
\hline
\end{tabular}

\section{Issuer size and takeover defenses: The "ISS Effect."}

Figure 5 shows that the incidence of board classification in the IPO sample is significantly higher than frequency of board classification in already-public companies. In fact, a company undergoing an IPO is almost twice as more likely to have a classified board than a company in the Russell 2000 index. However, this does not account for the size of the company. Figure 6 illustrates board classification in the IPO sample by market cap decile, matched against comparably sized public companies. ${ }^{* * * * * * * * * * * * * * * * * * * * * * * * * * *}$ Even when controlling for size, it is clear that the rate of classification in IPOs is higher than it

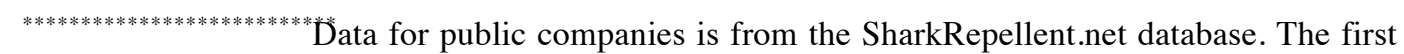
nine deciles represent companies in the Russell 2000 index, while the largest decile includes S\&P 500 companies. 
is in public companies. Therefore, the high incidence of takeover defenses in IPOs cannot be simply explained away by pointing to the size of the companies.

Figure 5

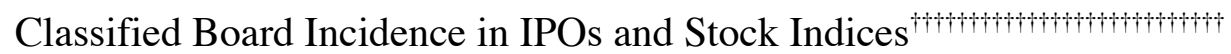

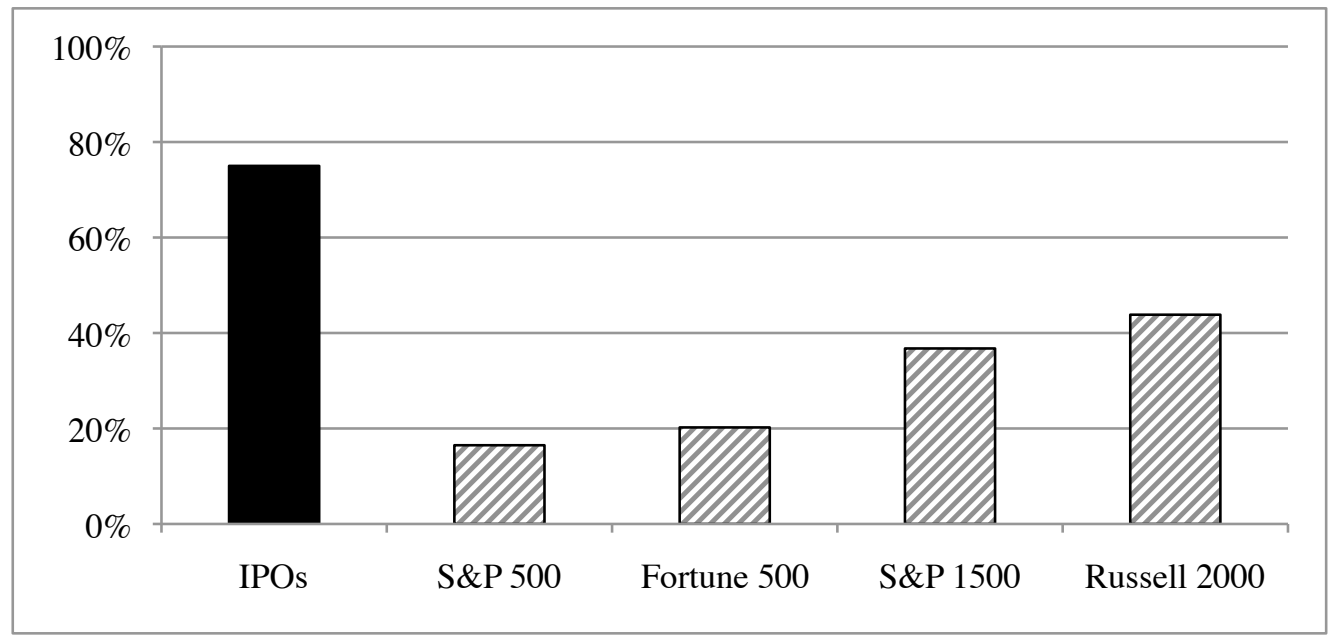

FIGURE 6

Classified Board Incidence in IPOs Matched to Comparably Sized Public Companies

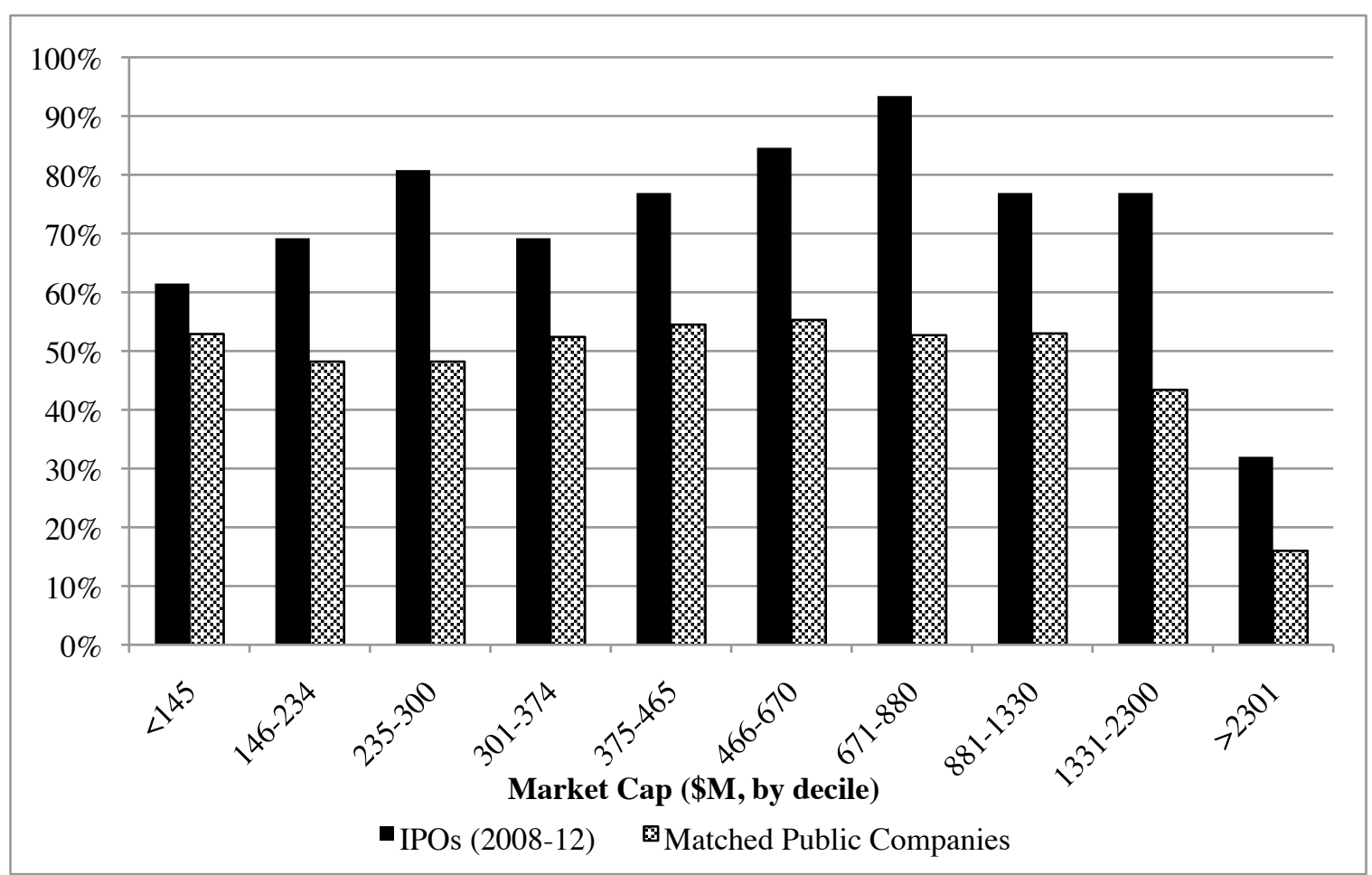

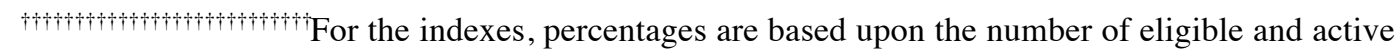
companies in the SharkRepellent.net database as of Feb. 28, 2013. 
Figure 6 also illustrates that there is a significant drop-off in classified board incidence for the companies with the largest market caps in the sample (those valued at over \$2.3 billion). This is consistent with anticipated pressure from institutional shareholders as there is a high correlation $(r=0.73)$ between market capitalization and the number of institutional investors. I call this the "ISS effect," a finding consistent with

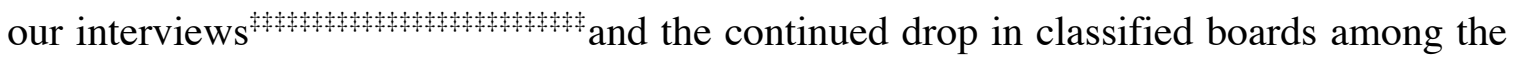
very largest (S\&P 500 and Fortune 500) mature public companies. As discussed above in Part II.A.2 these companies - which typically receive the most publicity-have been frequent targets of shareholder activists and have faced the most pressure and significant numbers of shareholder proposals to declassify.

\section{Summary of mean comparisons \& univariate regressions.}

The prevalence of takeover defenses - specifically, effective classified boards - at IPO companies is much greater than the incidence of such defenses at mature public companies. The identity of an issuer's legal counsel appears to affect the number of and choice of takeover defenses, as well as their effectiveness, consistent with what the law firm hypotheses suggest. The location of legal counsel also appears to have a relationship with takeover defenses. However, given high correlations between law firm location and financial sponsor type, it is difficult to draw any definitive conclusion on this point from a univariate regression.

Venture capital backing appears to have a tremendously strong correlation with takeover defenses. While private equity backing seems to be associated with the presence of some takeover-facilitating provisions, it is unclear what the overall relationship is between PE-backing and takeover defenses. The high prevalence of anti-takeover provisions in VC-backed companies is consistent with the Private Benefits hypothesis and is the opposite of what the Institutional Investor Efficiency and Substitute Governance hypotheses predict.

Finally, there is some evidence marginally consistent with the Management Entrenchment hypothesis as takeover defenses are more likely to be found in IPO companies with a founding CEO and in those with younger CEOs. However, as the coefficient for a CEO-Chairman is not statistically significant, there is not enough evidence from univariate regressions to draw any concrete conclusions regarding the hypothesis.

8. Charter provisions in private equity backed issuers.

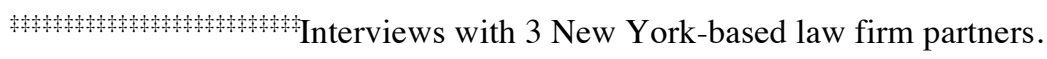


A small number of private equity-backed companies went public with unusual charter provisions that are worth examining. Appendix A details a sample of such provisions. Two companies went public with charter provisions in which a requirement that directors may only be removed for cause through a supermajority of the shareholder vote would be triggered as soon as the private equity sponsors ceased to own a controlling stake in the company. Such provisions appear to have the effect of maintaining private equity firms' flexibility while they still hold a meaningful share of the company. These provisions, however, then essentially give the private equity funds veto power over the removal of directors even after share ownership becomes more dispersed. And even after the private equity firm sells all of its shares of the company, the public shareholders are stuck with these onerous provisions that allow for an effective staggered board. One IPO issuer (Graham Packaging Company) had a similar charter provision in which a requirement that directors may only be removed for cause through a supermajority vote only applied when the private equity sponsor (Blackstone) owned between $10 \%$ and $50 \%$ of the stock. This provision also essentially gives the private equity sponsor veto power even as it sells down its stake. However, it does not leave public shareholders out in the cold once the private equity firm exits the company as it ceases to apply once their ownership falls below $10 \%$. Finally, in one instance a charter contained a provision that would automatically classify the board into three classes after the company's private equity owners cease to own a majority of the company's shares

The presence of these charter provisions lends support to the theory that private equity and venture capital firms install takeover defenses in charter companies in order to extract private benefits of control. They effectively give private equity funds veto rights in any battle to remove or replace the companies' boards while the funds still own sizeable stakes. The variation in the drafting of these provisions also evidences an agency problem between lawyers and a company's other shareholders. It is obvious that all of these provisions were drafted for the benefit of the private equity funds. However, only one law firm-Simpson Thacher, which represented $25 \%$ more acquirers than targets in public M\&A transactions - appears to have balanced the private equity funds' desire for anti-takeover provisions with the desires of other pre-IPO shareholders (by providing for at-will removal by a simple majority of the vote once the private equity firm owns less than $10 \%$ ).

\section{Mutual funds and pension funds as pre-IPO shareholders.}

A mutual fund or public pension fund was one of the top three pre-IPO shareholders for nine companies in the sample. Fidelity, Vanguard, Alberta Investment Management Corp ("AIMCo"), and the Ontario Teachers' Pension Plan ("Ontario Teachers") held pre-IPO stakes ranging from $7 \%$ to $49 \%$. As discussed in Part II.A.2, pension funds and mutual funds have been the institutional investors that have most 
vigorously opposed takeover defenses such as classified boards in public companies. All of these mutual and pension funds have adopted public policies supporting annual elections and opposing effective staggered boards (available in Appendix B). In fact, Ontario Teachers' explicitly states that classified boards may result in "permanent impairment of long-term shareholder value." $§ \S \S \S \S \S \S \S \S \S \S \S \S \S \S \S \S \S \S \S \S \S$

Against all expectations, seven out of the nine companies in this sub-sample went public with an effective staggered board. And one of the two firms without an ESB had an effective dual class control capital structure instead. These results are both unexpected and revealing. Mutual funds appear to be hypocrites when it comes to matters of corporate governance in pre-IPO portfolio companies. Although the SEC requires mutual funds to disclose their proxy voting policies and procedures, ${ }^{* * * * * * * * * * * * * * * * * * * * * * * * * * * * *}$ it does not require funds to disclose whether they actually complied with those internal policies and guidelines in situations other than formal proxy votes. This lack of transparency decreases the pressure that mutual funds face to institute or push for optimal governance arrangements at pre-IPO portfolio companies. One possible objection to drawing such a conclusion may be that mutual funds do not have controlling positions in these issuers and therefore are not in control of the governance arrangements that they adopt. However, in four out of the nine examples in the sub-sample, the mutual fund had at least a $25 \%$ stake, and Ontario Teachers' had an almost 50\% stake in GNC Holdings. It is difficult to believe that influential investors holding significant stakes have no influence

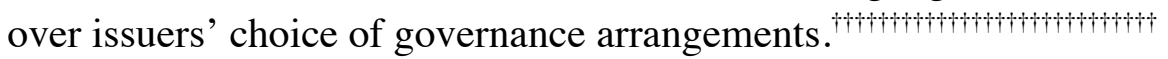

TABLE 11

Takeover Defenses in Mutual and Pension Fund Backed IPOs

\begin{tabular}{lclc}
\hline \hline Pre-IPO Holder & Pre-IPO stake & Issuer & $\begin{array}{c}\text { Issuer had ESB or } \\
\text { DualClassControl? }\end{array}$ \\
\hline Fidelity (Ventures) & $41.9 \%$ & Exa Corp. & Yes \\
Fidelity & $10.9 \%$ & Fluidigm Corp. & Yes \\
Fidelity & $10.0 \%$ & GenMark Diagnostics & Yes \\
Fidelity & $11.1 \%$ & KYTHERA Biopharmaceuticals & Yes \\
Fidelity & $7.0 \%$ & Merrimack Pharmaceuticals & No
\end{tabular}

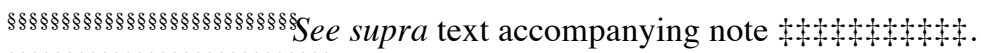

T"he SEC requires mutual funds to disclose their proxy voting policies, procedures, and records. Disclosure of Proxy Voting Policies and Proxy Voting Records by Registered Management Investment Companies, 68 Fed. Reg. 6564, 6564 (Feb. 7, 2003) (codified at 17 CFR pts. 239, $249,279 \& 274$ (2013)). The SEC believed that disclosure would "illuminate potential conflicts of interest and discourage voting that is inconsistent with fund shareholders' best interests" and that increasing the transparency of proxy voting by funds would lead funds to become more engaged in corporate governance issues. Id. at 6566 .

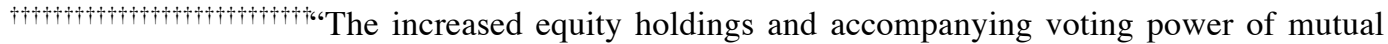
funds place them in a position to have enormous influence on corporate accountability. As major shareholders, mutual funds may play a vital role in monitoring the stewardship of the companies in which they invest." Disclosure of Proxy Voting Policies, supra note ***************************, at 6565. 


\begin{tabular}{llll} 
Vanguard & $10.7 \%$ & Vocera Communications & Yes \\
AIMCo & $26.1 \%$ & Bonanza Creek Energy & Yes \\
AIMCo & $26.3 \%$ & KiOR & Yes \\
Ontario Teachers' & $48.9 \%$ & GNC Holdings & Yes \\
\hline
\end{tabular}

Another plausible explanation for this hypocrisy may result from the separation of investing and voting functions in some mutual funds. ${ }^{*}$ w investment managers rely on designated non-portfolio management personnelsometimes referred to as internal "corporate governance" staff-to vote portfolio companies' shares, while other funds simply rely on third-party proxy advisory services

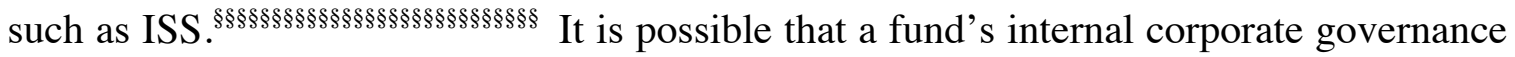
staff is not involved in -and is possibly unaware of - the corporate governance of preIPO portfolio companies, and it is almost certain that proxy advisory services are not involved. If this is the case, then investing personnel who are not knowledgeable in corporate governance issues may be responsible for the observed sub-sample results. Nevertheless, mutual funds and their advisors still have fiduciary responsibilities that require them to oversee these functions. ${ }^{* * * * * * * * * * * * * * * * * * * * * * * * * * * * * * * * *}$ Another possible excuse may be that mutual funds and public pension funds are passive investors. However, they have long ago admitted that being passive and pushing for good corporate governance are not mutually exclusive. It is difficult to see how voicing their views on corporate governance before an IPO is taking an activist approach while voicing those views after an IPO is consistent with passivity.

The fact that these mutual and public pension funds appear to care about corporate governance only when their efforts are easily observable draws into doubt their credibility and public stances on what constitutes "good governance." It may lead one to question whether such funds actually believe in their governance policy positions or if they instead simply adopt whatever position looks best on paper. Can we genuinely rely on them as 'stewards' of proper corporate governance when they fail to follow their principles at the time they have the most influence?

\section{Multivariate Regressions and Analysis}

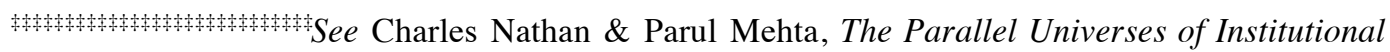
Investing and Institutional Voting, HARV. LAW SCHOOL FORUM ON CORP. GOV.\& FIN. REG., April 6, 2010, http://blogs.law.harvard.edu/corpgov/2010/04/06/the-parallel-universes-of-institutional-investing-andinstitutional-voting/ (alleging that that this separation is the "prevailing paradigm").

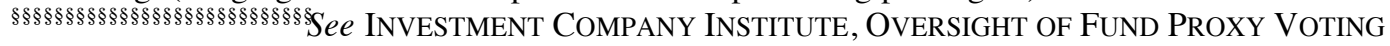
4 (2008), http://www.ici.org/pdf/ppr_08_proxy_voting.pdf.

Sec. \& Exch. Comm'n v. Capital Gains Research Bureau, Inc., 375 U.S. 180, 191 (1963) (holding that the Investment Advisers Act of 1940 recognizes a fiduciary relationship); INVESTMENT COMPANY INSTITUTE, supra note $\S \S \S \S \S \S \S \S \S \S \S \S \S \S \S \S \S \S \S \S \S \S \S \S \S \S \S$, at 1 (noting that boards remain responsible for oversight proxy voting functions even if the board delegates it to another party). 
Three sets of regressions are presented in order to explore the determinants of takeover defenses using the hypotheses first described in Part II. In all of the regressions, a spline function is used to control for the relationship between firm market capitalization and board classification. A two-segment (piecewise) spline function is a statistical method that can account for a structural change, or threshold, in the relationship between two variables. largest companies-referred to as the "ISS Effect" and illustrated earlier in Figure 6-is a structural change that indicates the need for a spline function.

The takeover defenses of most interest are effective staggered boards (ESB) and dual class structures with a controlling class. While the E-Index is also a useful measure, it is simply a more noisy measure. Nonetheless, I still report some models using the $E$ Index for illustrative purposes and to allow for comparisons to studies relying on that

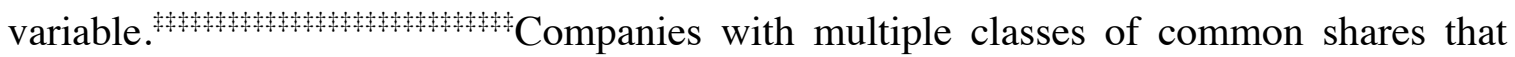
are selling low- or no-vote stock in their IPOs (DualClassControl=1) are analyzed separately and excluded from other models because the presence of such structures render board classification irrelevant

\section{Law firm models.}

Table 12 presents multivariate regressions in order to examine whether the data supports the Law Firm Role or Law Firm M\&A hypotheses, along with the Silicon Valley Effect hypothesis. Models (1), (3), and (4) present logistic regressions in which the dependent variable is a dummy variable equal to 1 if an issuer has an effective staggered board (ESB). Model (2) presents an ordered logistic regression in which the issuer's E-Index is the dependent variable. All of the models report the expected odds ratio. An odds ratio greater than 1.0 ("positive") implies that an increase in the explanatory variable is associated with an increase in the probability that an issuer has takeover defenses while an odds ratio less than 1.0 ("negative") implies that an increase in the explanatory variable is expected to be associated with a decrease in the probability.

In Model (1), the odds ratio for the number of M\&A transactions for which an issuer's counsel represented targets (Law Target Deals) is positive and highly significant $(p<0.006)$ and the odds ratio for the number of acquirer-side M\&A transactions (Law Acquirer Deals) is negative and significant $(p<0.027)$. A change of Law Target Deals from the 25 th percentile (7 transactions) to the 75 th percentile (31) is expected to increase the probability of having an ESB by $27.3 \%$ while a change of Law Acquirer Deals from

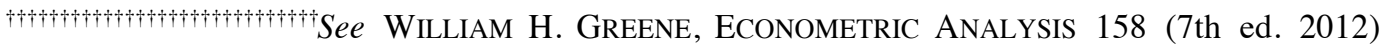
(describing spline function); Joanna M. Shepherd, Deterrence Versus Brutalization: Capital Punishment's Differing Impacts Among States, 104 MICH. L. REV. 203, 254 (2005) (using spline function in a model).

特 reported exponentiated coefficients to be materially different. 
the 25 th percentile (4) to the 75 th percentile (26) is expected to decrease the probability

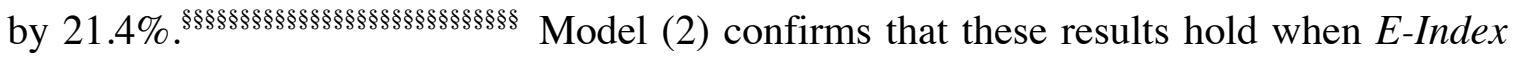
is the dependent variable in an ordered logit regression. Both models are consistent with the Law Firm Role hypothesis, which predicts a statistically significant odds ratio greater than 1 for Law Target Deals and less than 1 for Law Acquirer Deals. The more M\&A targets that a law firm represents, the higher the probability that an issuer using that law firm adopts an ESB. The results also lead me to reject the Law Firm M\&A hypothesis, which predicted that both of these odds ratios would be positive and significant.

Model (3) uses an alternative specification for the law firm hypotheses. The expected odds ratio for the Law More Target Deals, a dummy variable set to 1 if issuer's counsel represented more targets than acquirers in M\&A transactions, is strongly positive and significant $(p<0.013)$. It indicates that the odds that an issuer goes public with an ESB are more than twice as high for issuers using a law firm that represents more M\&A targets than acquirers than those using other law firms.. Meanwhile, the odds ratio for Law Total Deals is not statistically significant $(p<0.343)$, indicating that overall M\&A experience is not associated with a change in the probability of an ESB." Therefore, Model (3) is also consistent with the Law Firm Role hypothesis and inconsistent with the Law Firm M\&A hypothesis.

Model (4) is used to test the Silicon Valley Effect hypothesis. The odds ratio of the Silicon Valley Law indicator coefficient is positive and somewhat significant. The model indicates that issuers using a Silicon Valley lawyer as legal counsel are more than twice as likely to use an effective staggered board than other issuers, consistent with the hypothesized Silicon Valley Effect. However, as discussed in Part IV.B.2, there is a linear relationship between Silicon Valley Law and Venture Capital that makes it difficult to discern exactly which of the two variables is responsible for the results in this model. Law Target Deals remains statistically significant and positive in this model $(p<0.041)$ and Law Acquirer Deals is still less than 1.0. The standard errors of both variables are higher in this model, indicating possible multicollinearity between these variables and Silicon Valley Law. Nevertheless, the results are also consistent with the Law Firm Role hypothesis.

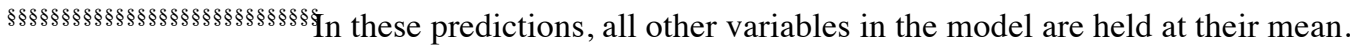

* In an unreported regression, I added an interaction of Law More Target Deals and Law Total Deals to the alternative specification of Model (2). In that regression, the signs and significance of the explanatory variables did not change and the interaction variable's coefficient was not statistically significant. 


\section{TABLE 12 \\ Law Firm Hypotheses}

Models 1 and 2 are logistic regressions in which the dependent variable equals one if the issuer had an effective staggered board $(E S B)$ when it went public. Model 3 is an ordered logistic regression in which the dependent variable equals the E-Index, ranging from 0 to 5 , for the issuer when it went public. The sample consists of 236 initial public offerings issued between 2008 and 2012 for which there was no controlling dual class capital structure. The $p$-values are reported in parentheses. Law Target (Acquirer) Deals is the number of public M\&A transactions for which an issuer's legal counsel represented the target (acquirer) in the 3 years prior to the IPO. Silicon Valley Law is a dummy set to one if legal counsel is from the Silicon Valley. Law More Target is a dummy variable equal to one if the issuer's legal counsel represented more targets than acquirers in public M\&A transactions. Law Total Deals is the total number of M\&A transactions for which an issuer's legal counsel represented the target or the acquirer. Industry M\&A is the number of public M\&A transactions that occurred in an issuer's 3-digit SIC industry in the 3 years prior to the IPO. Delaware is a dummy variable equal to one if the issuer is incorporated in Delaware. IPO Float is the percentage of shares offered in an IPO. Company Age is the age of the issuer at its IPO. Market Cap is the market cap ( $\$ \mathrm{M})$ of the issuer up to the $90^{\text {th }}$ percentile before the IPO. Large Market Cap is the market cap $(\$ \mathrm{M})$ of issuers in the $90^{\text {th }}$ percentile (the largest companies).

\begin{tabular}{|c|c|c|c|c|}
\hline & $\begin{array}{c}(1) \\
\text { ESB } \\
\end{array}$ & $\begin{array}{c}(2) \\
\text { E-Index } \\
\end{array}$ & $\begin{array}{c}(3) \\
\text { ESB } \\
\end{array}$ & $\begin{array}{c}(4) \\
\text { ESB } \\
\end{array}$ \\
\hline Law Target Deals & $\begin{array}{l}1.048^{* * *} \\
(0.006)\end{array}$ & $\begin{array}{l}1.045^{* * *} \\
(0.002)\end{array}$ & & $\begin{array}{l}1.037^{* *} \\
(0.041)\end{array}$ \\
\hline Law Acquirer Deals & $\begin{array}{l}0.958^{* *} \\
(0.027)\end{array}$ & $\begin{array}{c}0.958^{* * *} \\
(0.006)\end{array}$ & & $\begin{array}{c}0.968 \\
(0.111)\end{array}$ \\
\hline Law More Target & & & $\begin{array}{l}2.337^{* *} \\
(0.013)\end{array}$ & \\
\hline Law Total Deals & & & $\begin{array}{c}1.004 \\
(0.343)\end{array}$ & \\
\hline Silicon Valley Law & & & & $\begin{array}{c}2.787^{*} \\
(0.061)\end{array}$ \\
\hline Industry $M \& A$ & $\begin{array}{l}1.014^{* * *} \\
(0.002)\end{array}$ & $\begin{array}{l}1.014^{* * *} \\
(0.000)\end{array}$ & $\begin{array}{c}1.016^{* * *} \\
(0.001)\end{array}$ & $\begin{array}{l}1.013^{* * *} \\
(0.003)\end{array}$ \\
\hline Delaware & $\begin{array}{l}5.542^{* * *} \\
(0.007)\end{array}$ & $\begin{array}{l}2.709^{* *} \\
(0.045)\end{array}$ & $\begin{array}{c}5.179^{* * *} \\
(0.009)\end{array}$ & $\begin{array}{l}4.626^{* *} \\
(0.016)\end{array}$ \\
\hline IPO Float & $\begin{array}{c}0.961^{* * *} \\
(0.000)\end{array}$ & $\begin{array}{c}0.972^{* * *} \\
(0.000)\end{array}$ & $\begin{array}{c}0.963^{* * *} \\
(0.001)\end{array}$ & $\begin{array}{c}0.9666^{* * *} \\
(0.002)\end{array}$ \\
\hline Company Age & $\begin{array}{c}1.013 \\
(0.130)\end{array}$ & $\begin{array}{c}1.003 \\
(0.675)\end{array}$ & $\begin{array}{c}1.013 \\
(0.125)\end{array}$ & $\begin{array}{c}1.013 \\
(0.113)\end{array}$ \\
\hline Market Cap & $\begin{array}{c}1.040 \\
(0.195)\end{array}$ & $\begin{array}{l}1.048^{* *} \\
(0.040)\end{array}$ & $\begin{array}{c}1.049 \\
(0.123)\end{array}$ & $\begin{array}{c}1.036 \\
(0.232)\end{array}$ \\
\hline Large Market Cap & $\begin{array}{c}0.999^{* * *} \\
(0.000)\end{array}$ & $\begin{array}{l}1.000^{* *} \\
(0.017)\end{array}$ & $\begin{array}{c}0.999^{* * *} \\
(0.000)\end{array}$ & $\begin{array}{c}0.999^{* * *} \\
(0.001)\end{array}$ \\
\hline Year Dummies & Yes & Yes & Yes & Yes \\
\hline Chi-squared & $77.697^{* * *}$ & $71.719^{* * *}$ & $77.100^{* * *}$ & $81.655^{* * * *}$ \\
\hline
\end{tabular}


Pseudo $R^{2}$

0.249

0.117

0.247

$<0.01$

0.262

Reporting odds ratios (exponentiated coefficients); ${ }^{*} p<0.10,{ }^{* *} p<0.05,{ }^{* * *} p<0.01$

All models also include a set of control variables. Consistent with Daines \& Klausner ${ }^{\dagger}$ and Coates, ${ }^{\ddagger}$ a higher level of M\&A activity (Industry $M \& A$ ) in an issuer's industry is associated with a higher probability that an issuer goes public with takeover defenses in all models. Delaware incorporation (Delaware) is strongly positive and significant, implying that Delaware-incorporated companies are over five times more likely to have an ESB than companies incorporated elsewhere. This result is also consistent with Coates. ${ }^{\S}$ The odds ratio for IPO Float is negative and highly significant in all models, indicating that there is a lower probability that IPOs offering the most shares (as a percentage of total shares) will have an ESB. Company age was not significant in any model. Large Market Cap, a variable representing the size of the largest issuers, is negative and highly significant $(p<0.001)$, consistent with the prediction of an "ISS Effect." The goodness-of-fit measure (pseudo R-squared) for the ESB models is around 0.25 , suggesting that the model is properly identified.** Additionally, there is no reason to expect that the law firm M\&A variables introduce any endogeneity issues. Recall that Coates found that there were no testable differences in the clientele of law firms. ${ }^{\dagger \dagger}$ Issuers choose their law firms far in advance of their decisions to go public based and do not base their choice of law firms on the firms' beliefs about takeover defenses such as an ESB. ${ }^{\ddagger}$ Additionally, law firm switching costs for issuers are particularly high. ${ }^{\S}$

These results reveal that legal advice appears to have a significant impact on whether an issuer chooses to adopt takeover defenses and that this legal advice is influenced by the side of the table that a law firm sits in M\&A transactions. As discussed in Part IV.B.1, the identity of an issuer's legal counsel also appears to affect whether or not the adopted takeover defenses are actually effective. In his study of IPOs in the 1990s, Coates noted, "One can say with high confidence that lawyers with more M\&A proficiency are more knowledgeable about, pay more attention to, and are more likely to advise clients to adopt defenses."*** My results directly contradict Coates's findings with respect to IPOs between 2008 and 2012, as overall M\&A proficiency has no correlation with the adoption of takeover defenses in the sample. Coates, however, had no

\footnotetext{
${ }^{\dagger}$ Coates, Blame the Lawyers, supra note $+\uparrow+\uparrow+\uparrow+\uparrow+\uparrow+\uparrow+\uparrow \dagger$, at 1370; Daines \& Klausner, supra note $+\uparrow+\uparrow+\uparrow+\uparrow+\uparrow$, at 102 .

$¥$ Coates, Blame the Lawyers, supra note $+\dagger+\uparrow+\dagger+\dagger+\dagger+\dagger+\dagger \dagger$, at 1366. companies).

$\S I d$. at 1366 (reporting higher incidence of takeover defenses at Delaware-incorporated

${ }^{* *}$ For an overview of goodness-of-fit measures for logistic models, see JEFFREY M. WOOLDRIDGE, ECONOMETRIC ANALYSIS OF CROSS SECTION AND PANEL DATA 465 (2010).

${ }^{\dagger \dagger}$ Coates, Blame the Lawyers, supra note $+\dagger+\dagger+\dagger+\dagger+\dagger+\dagger+\dagger \dagger$, at 1378.

Id. at 1314 .

§See id. at 1316-17; Ronald Gilson, The Devolution of the Legal Profession: a Demand Side Perspective, 49 MD. L. REV. 869, 900 (1990).

${ }^{* * *}$ Coates, Blame the Lawyers, supra note $+\uparrow+\uparrow+\dagger+\dagger+\uparrow+\uparrow+\dagger+$, at 1378.
} 
expectation that his conclusions would persist. He recognized that defenses had become more common and uniform - and that the relationship between overall M\&A proficiency and defense adoption weakened - throughout the 1990s as learning occurred, ${ }^{\dagger \dagger}$ and he correctly hypothesized that the legal industry would transform as firms diversify. Simultaneously, M\&A law firms' expertise on takeover defenses has diffused to nonM\&A firms, which now recognize the importance of the issue. ${ }^{\S \S}$ We can also generally reject Bebchuk's explanation based on law firm self-interest. There is no reason to expect that lawyers' incentives to avoid reputational harm caused by the takeover of a client would be relevant only for law firms that predominantly represent M\&A targets, or that law firms that represent acquirers would be more likely to act against their self-interest. While Bebchuk's hypothesis fails to explain the variation in defense adoption within the sample, it nevertheless may still help explain why overall adoption has increased since the 1990s.

We can also reject the idea that defenses are generally optimal for pre-IPO ownermanagers today. Coates concluded that the correlation between law firms' M\&A proficiency and IPO takeover defenses indicated that law firms recognized that defenses were generally optimal at the time. ${ }^{* * * *}$ Although defenses may have been optimal in the mid 1990s, that theory no longer holds today because overall M\&A knowledge and experience are no longer correlated to the adoption of defenses. The lack of a consensus amongst the most knowledgeable law firms prevents us from looking to them for an efficiency-based explanation. One possible explanation for these new results may lie in the changes in executive compensation over the past two decades. Executive compensation from selling the company is much higher now than it was in the 1990s. ${ }^{\text {it }}$ The "golden parachute" payments that executives can receive in a takeover may decrease the value of trying to preserve private benefits through the use of takeover defenses.

As takeover defense adoption is correlated with law firms' roles, one can reasonably conclude that legal advice on defenses is influenced by anecdotal evidence within a law firm rather than empirical data or a systemic evaluation of the relevant evidence. Law firms that predominantly represent targets may believe that takeover defenses are valuable to shareholders while law firms that represent more acquirers may believe that defenses impede value-creating takeovers and hurt shareholders. An

${ }^{\dagger \dagger}$ See id. at 1378.

See id. at 1384.

$\$ \S \S$ For example, $100 \%$ of the issuer's advised by Gunderson Dettmer went public with an ESB, even though Gunderson Dettmer only had experience with 1 M\&A transaction. In the early 1990s, issuers advised by such a firm almost never went public with such a defense.

${ }_{* * * *}^{*}$ See id. at 1383 .

${ }^{\dagger \dagger}$ See Paul Hodgson \& Greg Ruel, Twenty-One U.S. CEOs with Golden Parachutes of More than $\$ 100$ Million (GMI Ratings, Jan. 2012), available at http://origin.library.constantcontact.com/download/get/file/1 10256168627569/GMI_GoldenParachutes_012012.pdf. 
alternative explanation rooted in Bebchuk's hypothesis is that the pain of losing a client is more salient to target law firms, causing them to prefer defenses. However, this hypothesis does not explain why acquirer-side M\&A experience would have a negative correlation with the inclusion of takeover defenses or why overall M\&A experience has no correlation.

\section{Private equity \& venture capital models.}

The multivariate regressions used to assess the private equity and venture capital hypotheses are presented in Table 13. Model (1) presents a logistic regression in which the dependent variable is a dummy variable equal to 1 if an issuer has an effective staggered board (ESB) while Model (2) presents an ordered logistic regression in which the issuer's E-Index is the dependent variable.

In Models (1) and (2), the odds ratio for Venture Capital Backing is extremely strong and significant $(p<0.001)$. Venture capital backed companies were over seven times more likely to go public with an ESB. This result persists even after controlling for the level of M\&A in the issuer's industry, the issuer's size, and other explanatory variables. On the other hand, Private Equity Backing does not appear to have a statistically significant effect on the adoption of takeover defenses such as an ESB. With respect to Venture Capital Backing, the results are consistent with the VC Private Benefits hypothesis and inconsistent with the VC Institutional Investor Efficiency and Substitute Governance hypotheses. On the other hand, the results for Private Equity Backing fail to substantiate both the PE Private Benefits and PE Institutional Investor Efficiency hypotheses.

The robust, statistically significant effect of venture capital backing on the prevalence IPO takeover defenses is a novel and noteworthy development. Recall that Daines and Klausner found that the coefficients on the indicator variables for VC- and PE-backing were insignificant. ${ }^{+\neq}$Baker and Gompers posited that the insignificant result was due to the fact that venture capital and private equity firm ownership may substitute for the external market for corporate control by instituting better internal governance mechanisms. With respect to venture-backed firms, this explanation is inconsistent with my results. As discussed in Part II.C.4, venture capital firms lose their incentive to exercise their voice once a portfolio company is taken public in an IPO, and they seek to exit their investments after the expiration of IPO lock-ups. Additionally, they

Daines \& Klausner, supra note $+\uparrow+\uparrow+\dagger+\dagger \dagger$, at 95. Similarly, Field \& Karpoff found that the coefficient for venture backing was insignificant. See Field \& Karpoff, supra note ******, at 1870. 
give up most of their control rights at the $\mathrm{IPO}^{\S \S \S}$ and thus can no longer serve effective substitutes for the external market for corporate control.

\section{TABLE 13 \\ Private Equity \& Venture Capital Hypotheses}

Models 1 and 3 are logistic regressions in which the dependent variable equals one if the issuer had an effective staggered board $(E S B)$ when it went public. Model 2 is an ordered logistic regression in which the dependent variable equals the $E$-Index, ranging from 0 to 5 , for the issuer when it went public. Model (4) is a bivariate probit regression, where the first stage (unreported) includes Venture Capital as the instrumental (dependent) variable and TXHQ, MAHQ, NYHQ, NJHQ, CAHQ, and HIGHTECH as the independent variables. The sample consists of 235 initial public offerings issued between 2008 and 2012 for which there was no controlling dual class capital structure. The $p$ values are reported in parentheses. Private Equity (Venture Capital) Backing is a dummy variable equal to one if a private equity (venture capital) fund is one of the 3 largest pre-IPO shareholders of an issuer. Industry M\&A is the number of public M\&A transactions that occurred in an issuer's 3-digit SIC industry in the 3 years prior to the IPO. Delaware is a dummy variable equal to one if the issuer is incorporated in Delaware. IPO Float is the percentage of shares offered in an IPO. Company Age is the age of the issuer at its IPO. Market Cap is the market cap (\$M) of the issuer up to the $90^{\text {th }}$ percentile before the IPO. Large Market Cap is the market cap $(\$ M)$ of issuers in the $90^{\text {th }}$ percentile (the largest companies).

\begin{tabular}{|c|c|c|c|c|}
\hline & $\begin{array}{c}(1) \\
\text { ESB } \\
\end{array}$ & $\begin{array}{c}(2) \\
\text { E-Index } \\
\end{array}$ & $\begin{array}{c}(3) \\
\text { ESB } \\
\end{array}$ & $\begin{array}{c}\text { (4) second stage } \\
\text { ESB }\end{array}$ \\
\hline Private Equity Backing & $\begin{array}{c}1.280 \\
(0.613)\end{array}$ & $\begin{array}{c}1.480 \\
(0.312)\end{array}$ & $\begin{array}{c}1.724 \\
(0.319)\end{array}$ & \\
\hline Venture Capital Backing & $\begin{array}{l}7.291^{* * *} \\
(0.000)\end{array}$ & $\begin{array}{l}7.707^{* * *} \\
(0.000)\end{array}$ & $\begin{array}{l}9.800^{* * *} \\
(0.000)\end{array}$ & $\begin{array}{l}5.306^{* * *} \\
(0.000)\end{array}$ \\
\hline Industry $M \& A$ & $\begin{array}{c}1.007 \\
(0.140)\end{array}$ & $\begin{array}{l}1.008^{* *} \\
(0.034)\end{array}$ & $\begin{array}{l}1.010^{*} \\
(0.052)\end{array}$ & $\begin{array}{c}1.002 \\
(0.456)\end{array}$ \\
\hline Delaware & $\begin{array}{l}3.234^{*} \\
(0.076)\end{array}$ & $\begin{array}{l}1.684 \\
(0.314)\end{array}$ & $\begin{array}{l}2.777 \\
(0.128)\end{array}$ & $\begin{array}{l}2.108^{* *} \\
(0.038)\end{array}$ \\
\hline IPO Float & $\begin{array}{l}0.971^{* *} \\
(0.016)\end{array}$ & $\begin{array}{l}0.974^{* * *} \\
(0.002)\end{array}$ & $\begin{array}{l}0.970^{* *} \\
(0.014)\end{array}$ & $\begin{array}{l}0.983^{* *} \\
(0.018)\end{array}$ \\
\hline Company Age & $\begin{array}{l}1.016^{* *} \\
(0.047)\end{array}$ & $\begin{array}{l}1.009 \\
(0.150)\end{array}$ & $\begin{array}{l}1.016^{* *} \\
(0.050)\end{array}$ & $\begin{array}{l}1.009^{* *} \\
(0.044)\end{array}$ \\
\hline Market Cap & $\begin{array}{c}1.027 \\
(0.401)\end{array}$ & $\begin{array}{c}1.035 \\
(0.132)\end{array}$ & $\begin{array}{c}1.024 \\
(0.459)\end{array}$ & $\begin{array}{l}1.020 \\
(0.287)\end{array}$ \\
\hline Large Market Cap & $\begin{array}{l}0.999^{* * *} \\
(0.006)\end{array}$ & $\begin{array}{l}1.000^{*} \\
(0.051)\end{array}$ & $\begin{array}{l}0.999^{* * *} \\
(0.010)\end{array}$ & $\begin{array}{l}1.000^{* * * *} \\
(0.009)\end{array}$ \\
\hline Year Dummies & Yes & Yes & Yes & Yes \\
\hline $\begin{array}{l}\text { Excludes firms backed } \\
\text { by both VC \& PE }\end{array}$ & No & No & Yes & No \\
\hline$N$ & 235 & 235 & 222 & 235 \\
\hline
\end{tabular}

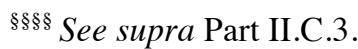




\begin{tabular}{|c|c|c|c|c|}
\hline Chi-squared & $86.870^{* * * *}$ & $92.354^{* * *}$ & $85.154^{* * * *}$ & $159.587^{* * *}$ \\
\hline Pseudo $R^{2}$ & 0.280 & 0.151 & 0.288 & \\
\hline
\end{tabular}

Reporting odds ratios (exponentiated coefficients); ${ }^{*} p<0.10,{ }^{* *} p<0.05,{ }^{* * *} p<0.01$

The results of Models (1) and (2) suggest that venture capital firms take advantage of agency problems in order to maintain outsize influence on companies after taking them public. While they give up many of their easily observable contractual control rights at an IPO, they are able to maintain informal non-contractual control through board representation and takeover defenses, even as they sell off their shares.

An alternative conclusion offered by others may be that venture capital funds may insist on having takeover defenses in order to cultivate a reputation for being friendly to entrepreneurs, as discussed in Part II.C.2. However, Bebchuk convincingly dismissed such an argument because funds only have an incentive to make such implicit commitments to managers if it would be expected to increase the joint surplus of the parties. Additionally, in interviews with fund managers, ${ }^{* * * *}$ reputational concerns with entrepreneurs were never offered as an explanation. Venture capital firms are typically known for exerting strong control rights from companies, not for giving up such rights. Finally, it is difficult to imagine that a manager of a start-up would actually have an ex ante opinion on whether or not the company should have a staggered board. Most start-up managers are not repeat players in the IPO market, do not have an advanced understanding of the perceived pros and cons of takeover defenses, and presumably rely on their experienced agents (lawyers) and financial sponsors to deal with such matters. And, in interviews, executives at venture capital firms have confirmed this. ${ }^{\text {titt }}$

It is notable - and rather surprising - that private equity backing does not have a statistically significant relationship with takeover defenses while venture capital backing does. Both venture capital and private equity firms are active, sophisticated, and presumably well-informed participants in the IPO market. They have similar incentives to make decisions that maximize the value of shares in IPOs of portfolio companies. The funds of venture capital and private equity firms are of limited duration and have similar investment horizons. I did not expect the results of financial backing to be distinct based on whether it was a private equity or venture capital fund. This result also leads us to reject the idea that takeover defenses are generally optimal for pre-IPO shareholders because, once again, the parties that presumably have the most IPO experience behave differently from one another.

${ }^{* * * * *}$ Interviewees included a co-founder and principal at a Silicon Valley venture capital firm, a principal at a Boston-based venture capital firm, and a former managing partner at a large private equity firm that also runs venture capital funds.

††廾门 $I d$. 
However, there is one vital disparity in the experience of private equity and venture capital firms: private equity firms have extensive experience in the public markets. While venture capital firms typically invest in private start-ups, private equity firms make many significant investments in public companies. Private equity firms have been involved in more than one-quarter of U.S. mergers in recent years. ${ }^{\star * \neq}$ Note that over a third of my IPO sample involved companies undergoing RLBOs, all of which were public companies before being taken private by private equity firms. Because they operate in the public market, private equity firms have first-hand experience with takeover defenses that insulate managers such as staggered boards. It is plausible that they are therefore more attuned to the negative effects associated with takeover defenses than venture capital firms that never have to deal with acquiring a public company. Even though private equity firms almost never engage in hostile transactions, it is not difficult to imagine that they have seen value-creating LBO transactions scuttled because entrenched managers hid behind takeover defenses. As experienced players in the public markets, private equity firms are also more aware of the significant declassification trends in public companies and therefore know that annual elections are inevitable.

Even though I reject the reputation-based explanation, I cannot discard the possibility that issuer managers are more fungible - and less important to the value of the company-in private equity-backed companies than in venture-backed firms. Private equity firms are known for having a knack to restructure management teams. ${ }^{\S \S \S \S}$ The value of portfolio companies is likely not dependent on the fungible operational team that is in place at the IPO. On the other hand, the value of some start-ups and other companies backed by venture funds may indeed be dependent on the management team. In companies such as Facebook, it is clear that a significant amount of the firm's value is tied to the management team. Managers like Mark Zuckerberg cannot easily be replaced. Thus, it is possible that venture capital firms may find it desirable to insulate management when they perceive that the company's value depends on the specific management team in place.

Finally, there is some reason to believe that limited partners may have less influence on the practices of the general partners in venture capital funds than they do in private equity. Because of their smaller size, ${ }^{* * * * * *}$ venture capital funds are more likely to be oversubscribed. As a result, limited partners regularly claim that venture capital firms

\footnotetext{
Katz, supra note $* * * * * * * * * * * * * * * * * * * * * * *$, at 624.

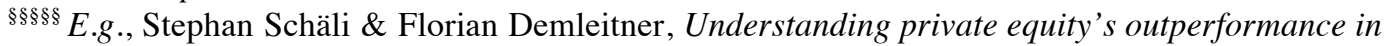
difficult times (Partners Group Research Flash, Jan. 2012), available at http://www.partnersgroup.com/display.cfm/id/100483/.

${ }^{* * * * * * *}$ See supra Part II.B.2.a for explanation of why venture capital funds are smaller.
} 
are often able to choose their investors. ${ }^{\|+1+1}$ Influential institutional investors may consequently choose to remain silent regarding their corporate governance beliefs and preferences in order to ensure access to these venture funds.

${ }^{+1+T_{i}}$ Berk A. Sensoy et al., Limited Partner Performance and the Maturing of the Private Equity Industry 8 (NBER Working Paper No. 18793, Feb. 2013), available at http://www.nber.org/papers/w18793. 


\section{a. Addressing Endogeneity and Measurement Error.}

There are two potential complications in these models that are worth discussing: endogeneity and measurement error inherent in the Venture Capital Backing and Private Equity Backing variables. Endogeneity is a concern because the selection of companies backed by venture capital and private equity funds may not be exogenous to characteristics of the companies. Measurement error may result from misclassification of venture capital and private equity firms.

As discussed in Part III.B, I attempted to minimize measurement error when recording values for Venture Capital Backing and Private Equity Backing by relying on an objective third-party source. In recent years, however, there has been some convergence between the two categories of investments as competition for deals has heated up. ${ }^{+1+\neq}$ The term "private equity" has increasingly been used as an umbrella covering both traditional private equity (LBO) firms and venture capital firms. ${ }^{\S \S \S \S \S}$ Additionally, many top private equity firms have begun to dip their toes into venture capital investments. ${ }^{* * * * * *}$ This concern is exhibited by the thirteen companies in the sample that were backed by both private equity and venture capital firms. For example, the private equity firm Summit Partners - which stresses the difference between private equity (growth equity) and venture capital ${ }^{1+t+1+\dagger}$ - launched a $\$ 520 \mathrm{M}$ venture capital fund (“Summit Partners Venture Capital Fund III") in 2012. this affects the interpretation of the results. The convergence seems to be unidirectional, as venture capital firms have not expanded into traditional private equity investments. ${ }^{\S \S \S \S \S \S}$ In interviews, executives at top firms that offer both private equity and venture capital funds, including Summit Partners, confessed that they did not apply different management philosophies to portfolio companies in the different funds. The chief distinction was just the size and timing of their investment.

${ }^{+}$See Nick Hazell \& Simon Walker, Private equity and venture capital investors used to keep their work separate, but now, in a disrupted world of finance, things are set to change, REALBUSINESS, Jan. 24, 2013, http://realbusiness.co.uk/article/17331-can-private-equity-and-venture-capital-work-together. In fact, Dow Jones \& Co. even merged its private equity and venture capital databases into a single platform. See Private Equity \& Venture Capital, DOW JONES, http://pevc.dowjones.com/.

§\$\$§\$See Pema Levy, The Media Is Confusing Private Equity And Venture Capital - To Mitt Romney's Benefit, TAlKInGPoInTSMemo, Jan. 23, 2013, http://2012.talkingpointsmemo.com/2012/01/themedia-is-confusing-private-equity-and-venture-capital----to-mitt-romneys-benefit.php.

${ }^{* * * * * * *}$ See Shira Ovide \& Pui-Wing Tam, New Money Ventures to Silicon Valley, WaLL ST. J., Mar. 8, 2013.

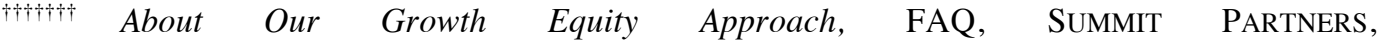
http://www.summitpartners.com/what-is-growth-equity.aspx, last accessed Mar. 29, 2013.

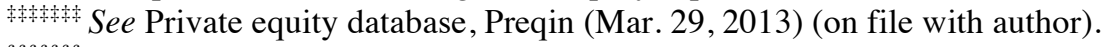

§§§§§§§ See Dan Primack, Venture capitalists: We don't do private equity, FoRTUNE, Jan. 20, 2012, http://finance.fortune.cnn.com/2012/01/20/venture-capitalists-we-dont-do-private-equity/. 
I eliminate the thirteen companies with both private equity and venture capital backing from the sample in Model (3). With the exception of Delaware, all of the exponentiated coefficients that were significant in Model (1) remain statistically significant in Model (3). This model arguably removes some noise from the data. As a result, the odds ratio for Venture Capital Backing has increased to 9.8, indicating that venture-backed companies are almost ten times more likely to go public with an effective staggered board than other companies. This result implies that the measurement error, if it has any effect at all, causes us to underestimate the impact of venture capital backing on the incidence of takeover defenses.

One conceivable difficulty in drawing conclusions from Model (1) is that the selection of which firms venture capital and private equity funds invest in is not exogenous to the characteristics of the firm and the CEO. As described by Baker and Gompers, we run a risk of falsely imputing a significant impact of venture capital because of the omission of unidentified company and CEO characteristics. ${ }^{* * * * * * * *}$ To address this, I employ a bivariate probit model to simultaneously estimate the likelihood that a company is backed by venture capital and the likelihood that the company has an effective staggered board. ${ }^{+1+t+1}$ A proper model uses instrumental variables that are strongly correlated with the presence of venture capital backing yet uncorrelated with other determinants of takeover defenses, both observed and unobserved. ${ }^{\$+1+\neq}$ Baker and Gompers identified two such instruments: (1) the state where the firm's headquarters are located and (2) a dummy variable set to one if the firm was founded after $1979.8 \S \S \S \S \S \S$

As the venture capital industry is concentrated in states such as California and as the cost of monitoring increases in proportion to the distance between a company's headquarters and its venture capital backers, Baker and Gompers argue that venture capital backing is related to the location of the company's headquarters. Additionally, as the amendment to the Employee Retirement Income Security Act ("ERISA") in 1979 allowed pension funds to invest in venture capital partnerships and dramatically increased capital inflows to venture capital funds, they contend that companies founded after 1979 have a higher probability of being backed by venture funds. Unfortunately, as 29 years have passed between the ERISA amendment and the first year of the sample, the ERISA dummy variable cannot be used as an instrument. ${ }^{* * * * * * * *}$ Instead, I use a categorical variable set to one if a company is in a high-tech industry. High-tech companies are often

\footnotetext{
*********Baker \& Gompers, supra note $\S \S$, at 579.

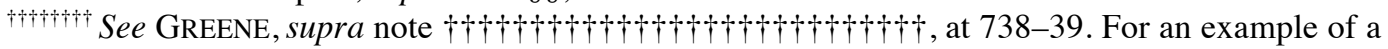
similar use of a bivariate probit model, see Yael V. Hochberg, Venture Capital and Corporate Governance in the Newly Public Firm, 16 REV. FIN. 429, 441 (2012) and Bates et al., supra note $\dagger \dagger \dagger+\dagger \dagger$, at 673.

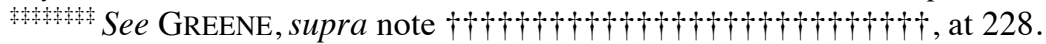

$\S \S \S \S \S \S \S$ Baker \& Gompers, supra note $* * * * * *$, at 579.

using the data sample.
} 
magnets for venture capital investors. The sample illustrates this relationship: $71 \%$ of venture-backed companies are in a high-tech industry while only $21 \%$ of non-venture companies are classified as high-tech.

Model (4) has two stages of equations that are simultaneously estimated by maximum likelihood regression. The first stage equation (unreported) is a model with Venture Capital Backing as the dependent variable. The independent variables are the categorical variables that indicate the state of a firm's headquarters (CAHQ, MAHQ, $N J H Q, N Y H Q$, and $T X H Q$ ) and a categorical variable set to 1 if the firm is in a high-tech industry $(H I G H T E C H)$. The second stage equation estimates the likelihood that there is an effective staggered board (ESB) using Venture Capital Backing and the control variables used elsewhere. The direction and significance of the results of Model (4) are virtually identical to Model (1). While the odds ratio for Venture Capital Backing is slightly lower in this model, it is still remarkably high and statistically significant at the $1 \%$ level. The results of this model are encouraging as they suggest that the exponentiated coefficient (odds ratio) for Venture Capital Backing in Model (1) does not arise from endogeneity and is not merely the result of ex ante selection.

\section{Management entrenchment models.}

Table 14 presents multivariate regressions testing the Management Entrenchment hypothesis. Model (1) presents a logistic regression in which the dependent variable is a dummy variable equal to 1 if an issuer has an effective staggered board (ESB) while Model (2) presents an ordered logistic regression in which the issuer's E-Index is the dependent variable.

In both models, none of the variables representing significant non-pecuniary benefits to management and entrenchment have a statistically significant relationship with the adoption of takeover defenses. The presence of a CEO-Founder, a CEOChairman, the age of the CEO, and the pre-IPO inside ownership of the company are not associated with the adoption of takeover defenses. 


\section{TABLE 14 \\ Management Entrenchment Hypothesis}

Models 1 is a logistic regression in which the dependent variable equals one if the issuer had an effective staggered board $(E S B)$ when it went public. Model 2 is an ordered logistic regression in which the dependent variable equals the E-Index, ranging from 0 to 5, for the issuer when it went public. The sample consists of 236 initial public offerings issued between 2008 and 2012 for which there was no controlling dual class capital structure. The $p$-values are reported in parentheses. CEO-Founder is a dummy variable equal to one if the CEO is also a founder of the issuer. $C E O$ Chairman is a dummy variable equal to one if the CEO also serves as chairman of the issuer's board. CEO Age is the age of the CEO. Inside Ownership is the percent of the issuer's common stock owned by directors and officers prior to the IPO. Industry $M \& A$ is the number of public M\&A transactions that occurred in an issuer's 3-digit SIC industry in the 3 years prior to the IPO. Delaware is a dummy variable equal to one if the issuer is incorporated in Delaware. IPO Float is the percentage of shares offered in an IPO. Company Age is the age of the issuer at its IPO. Market Cap is the market cap ( $\$ \mathrm{M})$ of the issuer up to the $90^{\text {th }}$ percentile before the IPO. Large Market Cap is the market cap (\$M) of issuers in the $90^{\text {th }}$ percentile (the largest companies).

\begin{tabular}{|c|c|c|c|}
\hline & $\begin{array}{c}(1) \\
\text { ESB }\end{array}$ & $\begin{array}{c}(2) \\
\text { E-Index }\end{array}$ & $\begin{array}{c}(3) \\
\text { ESB }\end{array}$ \\
\hline CEO-Founder & $\begin{array}{c}1.420 \\
(0.373)\end{array}$ & $\begin{array}{c}1.458 \\
(0.230)\end{array}$ & $\begin{array}{c}3.083^{*} \\
(0.082)\end{array}$ \\
\hline CEO-Chairman & $\begin{array}{c}0.888 \\
(0.739)\end{array}$ & $\begin{array}{c}0.760 \\
(0.329)\end{array}$ & $\begin{array}{c}1.023 \\
(0.951)\end{array}$ \\
\hline CEO Age & $\begin{array}{c}0.981 \\
(0.387)\end{array}$ & $\begin{array}{c}0.994 \\
(0.724)\end{array}$ & $\begin{array}{c}0.992 \\
(0.729)\end{array}$ \\
\hline Inside Ownership & $\begin{array}{c}1.005 \\
(0.302)\end{array}$ & $\begin{array}{c}1.007 \\
(0.105)\end{array}$ & $\begin{array}{c}1.004 \\
(0.423)\end{array}$ \\
\hline Private Equity Backing & & & $\begin{array}{c}1.910 \\
(0.263)\end{array}$ \\
\hline CEO-Founder in PE-Backed Issuer & & & $\begin{array}{c}0.542 \\
(0.282)\end{array}$ \\
\hline Venture Capital Backing & & & $\begin{array}{c}6.522^{* * *} \\
(0.002)\end{array}$ \\
\hline Industry $M \& A$ & $\begin{array}{l}1.014^{* * *} \\
(0.002)\end{array}$ & $\begin{array}{l}1.015^{* * *} \\
(0.000)\end{array}$ & $\begin{array}{c}1.006 \\
(0.223)\end{array}$ \\
\hline Delaware & $\begin{array}{l}6.335^{* * *} \\
(0.004)\end{array}$ & $\begin{array}{l}2.773^{* *} \\
(0.042)\end{array}$ & $\begin{array}{l}3.688^{*} \\
(0.060)\end{array}$ \\
\hline IPO Float & $\begin{array}{c}0.959^{* * *} \\
(0.001)\end{array}$ & $\begin{array}{c}0.966^{* * *} \\
(0.000)\end{array}$ & $\begin{array}{l}0.971^{* *} \\
(0.020)\end{array}$ \\
\hline Company Age & $\begin{array}{l}1.017^{* *} \\
(0.048)\end{array}$ & $\begin{array}{c}1.006 \\
(0.343)\end{array}$ & $\begin{array}{l}1.018^{* *} \\
(0.031)\end{array}$ \\
\hline Market Cap & $\begin{array}{c}1.035 \\
(0.264)\end{array}$ & $\begin{array}{l}1.047^{* *} \\
(0.048)\end{array}$ & $\begin{array}{l}1.030 \\
(0.374)\end{array}$ \\
\hline Large Market Cap & $\begin{array}{c}0.999^{* * *} \\
(0.000)\end{array}$ & $\begin{array}{l}1.000^{* *} \\
(0.030)\end{array}$ & $\begin{array}{l}0.999^{* *} \\
(0.011)\end{array}$ \\
\hline Year Dummies & Yes & Yes & Yes \\
\hline $\begin{array}{l}\text { Chi-squared } \\
\text { Pseudo } R^{2}\end{array}$ & $\begin{array}{c}71.673^{* * *} \\
0.233\end{array}$ & $\begin{array}{c}68.638^{* * * *} \\
0.113\end{array}$ & $\begin{array}{c}92.947^{* * * *} \\
0.302\end{array}$ \\
\hline
\end{tabular}

Reporting odds ratios (exponentiated coefficients); ${ }^{*} p<0.10,{ }^{* *} p<0.05,{ }^{* * *} p<0.01$ 
Recall that the two previous influential studies of the management entrenchment and private benefits hypothesis reached conflicting conclusions. Field and Karpoff found that takeover defenses were more likely to be used by companies with weak controls over senior management, such as firms with a CEO-Chairman, younger CEOs, and smaller insider holdings. ${ }^{\text {ttittit }}$ On the other hand, Daines and Klausner found that takeover defenses were more likely to be used when insiders had higher pre-IPO ownership and that the presence of a CEO-Founder had no correlation with takeover defenses. Although inconsistent with the results observed by Daines and Klausner, ${ }^{+1+1+}$ my results are consistent with their conclusion to reject the management entrenchment hypothesis. These results are not sensitive to changes in the model that account for multicollinearity between the independent variables of interest. . $^{\S \S \S \S \S \S \S}$

Interaction variables are useful when the effect of one variable on another depends on a third variable. ${ }^{* * * * * * * * *}$ As previously indicated in Table 9, the difference in the means of some of the management entrenchment variables, such as $C E O$-Founder, between the venture capital and the private equity subsamples is statistically significant. Therefore, in order to determine whether the relationship between the presence of a $C E O$ Founder and the inclusion of an effective staggered board is dependent on whether the company is backed by a venture capital or private equity firm, I interacted CEO-Founder with Private Equity Backing and Venture Capital Backing. ${ }^{+t_{t+1+t \dagger}}$ However, only the interaction for the Private Equity Backing added explanatory power to the model and provided statistically significant results. ${ }^{+t^{+}+t_{+\neq}}$Model (3) supplements the management entrenchment variables with Private Equity Backing, Venture Capital Backing, and an interaction between CEO-Founder and Private Equity Backing.

In Model (3), a non-private-equity-backed with a CEO-founder is three times more likely to have an effective staggered board than a company without a CEO-founder. This significant relationship does not persist in private equity backed companies, where there is no statistically significant relationship between the presence of a CEO-founder

${ }^{\dagger+1 \dagger+1 \dagger \dagger}$ Field \& Karpoff, supra note $* * * * * *$, at 1871.

They observed that takeover defenses were more protective when they were predicted to be the least efficient. However, my results show no relationship at all.

$\S \S \$ \$ \$ \$ \S \S$ CEO-Founder, CEO-Chairman, CEO Age, and Inside Ownership do not have a statistically significant coefficient if the other variables are eliminated from the model. Additionally, none of these variables has a significant correlation with another.

${ }^{* * * * * * * * * * *}$ CINDY D. KAM \& ROBERT J. FRANZESE, JR., MODELING AND INTERPRETING INTERACTIVE HyPOTHESES IN REGRESSION ANALYSIS: A REFRESHER AND SOME PRACTICAL ADVICE 18 (2005).

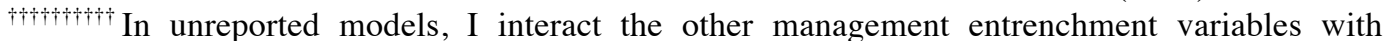
private equity and venture capital backing. The interactions did not add explanatory power to the model and the coefficients were not statistically significant.

Because of this - and in order to ease the interpretation of the interaction terms in a binary logit model-the interaction of CEO-Founder and Venture Capital Backing was dropped from the model. 
and takeover defenses $(0.542$ odds ratio, $p<0.282) .{ }^{\S \S \S \S \S \S \S \S}$ The coefficients for the other management entrenchment variables and Private Equity Backing are still insignificant, and the coefficient for Venture Capital Backing is still high and highly significant (6.522, $p<0.002)$. The effect of $C E O$-Founder on ESB lends some support to the management entrenchment hypothesis with respect to non-private-equity-backed issuers. In these issuers, it seems likely that CEO-Founders are using takeover defenses to entrench themselves in order to protect the private benefits they get from controlling the companies they founded. Additionally, as this result does not persist in private equity backed companies, and as the coefficient for Private Equity Backing is not statistically significant, the results add some credence to the Substitute Governance hypothesis described by Bakers and Gompers.

\section{Comprehensive models and dual class control model.}

Model (1) of Table 15 presents a logistic regression combining both the Law Firm and Venture Capital \& Private Equity hypotheses. While Law Acquirer Deals loses its statistical significance, the coefficient for Law Target Deals remains positive and significant $(p<0.083)$. Likewise, the odds ratio for Venture Capital Backing remains very high (5.7) and is significant $(p<0.003)$ and Private Equity Backing remains insignificant. As an increase in target-side M\&A experience for an issuer's legal counsel and the presence of venture capital backing is associated with a higher probability of an issuer going public with an effective staggered board, these results lend additional support to the Law Firm Role and Private Benefits hypotheses.

The significance of the relationship between Silicon Valley lawyers and the adoption of takeover defenses could not be tested in previous models because of the overlap between the use of Silicon Valley law firms and venture capital backing. Model (2) adds Silicon Valley Law to the Model (1). Its coefficient is not statistically significant, indicating that the use of a Silicon Valley law firm is not associated with an increased probability of an issuer going public with an effective staggered board. However, as discussed in Part IV.B.2, there is a rather strong correlation between Silicon Valley Law and Venture Capital ( $r=0.49$ ) that makes it difficult to disentangle the effects of each variable. Nevertheless, even with the higher standard errors possibly caused by multicollinearity, Venture Capital Backing remains highly significant and Law Target Deals still retains some statistical significance.

§§§§§§§§ The odds ratio for "CEO-Founder in PE-Backed Issuer" reported in Model (3) was estimated in accordance with Jokin de Irala-Estévez \& Miguel A. Martínez, Automatic estimation of interaction effects and their confidence intervals, 53 STATA TECHNICAL BULLETIN 29 (2000), http://statapress.com/journals/stbcontents/stb53.pdf. Odds ratios for models with interaction terms are not properly estimated in statistical computer packages and therefore require additional manual calculations. See

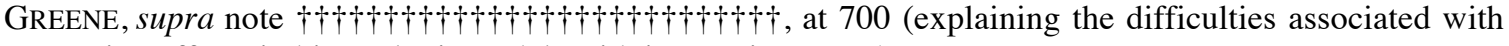
measuring effects in binary logit models with interaction terms). 


\section{TABLE 15}

\section{Comprehensive \& Dual Class Control Models}

All models are logistic regressions in which the dependent variable equals one if the issuer went public with an effective staggered board. The sample in models (1)-(3) consists of 236 initial public offerings issued between 2008 and 2012 for which there was no controlling dual class capital structure. The sample in model (4) consists of 250 initial public offerings during the same period. The $p$-values are reported in parentheses.

\begin{tabular}{|c|c|c|c|c|}
\hline & $\begin{array}{c}(1) \\
\text { Law Firm \& } \\
\text { VC/PE } \\
(\text { ESB })\end{array}$ & $\begin{array}{c}(2) \\
+ \text { Silicon } \\
\text { Valley Law } \\
(\text { ESB }) \\
\end{array}$ & $\begin{array}{c}(3) \\
+ \text { Managerial } \\
\text { Entrenchment } \\
(\text { ESB }) \\
\end{array}$ & $\begin{array}{c}\text { (4) } \\
\text { (Dual Class } \\
\text { Control) } \\
\end{array}$ \\
\hline \multicolumn{5}{|l|}{ Law Firm Variables: } \\
\hline Law Target Deals & $\begin{array}{l}1.036^{* *} \\
(0.043)\end{array}$ & $\begin{array}{c}1.033^{*} \\
(0.083)\end{array}$ & $\begin{array}{l}1.042^{* *} \\
(0.033)\end{array}$ & $\begin{array}{c}0.998 \\
(0.946)\end{array}$ \\
\hline Law Acquirer Deals & $\begin{array}{c}0.975 \\
(0.226)\end{array}$ & $\begin{array}{c}0.978 \\
(0.283)\end{array}$ & $\begin{array}{c}0.972 \\
(0.203)\end{array}$ & $\begin{array}{c}1.011 \\
(0.759)\end{array}$ \\
\hline Silicon Valley Law & & $\begin{array}{c}1.583 \\
(0.441)\end{array}$ & $\begin{array}{c}1.594 \\
(0.454)\end{array}$ & $\begin{array}{c}0.755 \\
(0.678)\end{array}$ \\
\hline \multicolumn{5}{|l|}{ Financial Sponsor Variables: } \\
\hline Private Equity Backing & $\begin{array}{c}1.280 \\
(0.624)\end{array}$ & $\begin{array}{c}1.318 \\
(0.582)\end{array}$ & $\begin{array}{c}2.264 \\
(0.182)\end{array}$ & $\begin{array}{l}0.096^{* * *} \\
(0.005)\end{array}$ \\
\hline Venture Capital Backing & $\begin{array}{l}6.393^{* * *} \\
(0.001)\end{array}$ & $\begin{array}{l}5.740^{* * *} \\
(0.003)\end{array}$ & $\begin{array}{l}5.267^{* * *} \\
(0.007)\end{array}$ & $\begin{array}{c}0.853 \\
(0.841)\end{array}$ \\
\hline \multicolumn{5}{|l|}{ Management Variables: } \\
\hline CEO-Founder & & & $\begin{array}{l}3.487^{*} \\
(0.058)\end{array}$ & $\begin{array}{c}1.649 \\
(0.376)\end{array}$ \\
\hline CEO-Chairman & & & $\begin{array}{c}1.076 \\
(0.849)\end{array}$ & $\begin{array}{c}1.278 \\
(0.642)\end{array}$ \\
\hline CEO Age & & & $\begin{array}{c}0.998 \\
(0.944)\end{array}$ & $\begin{array}{c}0.982 \\
(0.544)\end{array}$ \\
\hline Inside Ownership & & & $\begin{array}{c}1.005 \\
(0.409)\end{array}$ & $\begin{array}{c}1.000 \\
(0.985)\end{array}$ \\
\hline CEO-Founder in PE-Backed & & & 0.456 & 0.334 \\
\hline Issuer & & & $(0.182)$ & $(0.446)$ \\
\hline$\underline{\text { Control Variables }}$ & & & & \\
\hline Industry $M \& A$ & $\begin{array}{c}1.007 \\
(0.163)\end{array}$ & $\begin{array}{c}1.007 \\
(0.147)\end{array}$ & $\begin{array}{c}1.006 \\
(0.259)\end{array}$ & $\begin{array}{c}0.994 \\
(0.368\end{array}$ \\
\hline Delaware & $\begin{array}{l}3.075^{*} \\
(0.098)\end{array}$ & $\begin{array}{c}2.915 \\
(0.114)\end{array}$ & $\begin{array}{l}3.237^{*} \\
(0.099)\end{array}$ & $\begin{array}{c}0.820 \\
(0.816)\end{array}$ \\
\hline IPO Float & $\begin{array}{l}0.972^{* *} \\
(0.020)\end{array}$ & $\begin{array}{l}0.973^{\text {** }} \\
(0.027)\end{array}$ & $\begin{array}{l}0.973^{\text {** }} \\
(0.037)\end{array}$ & $\begin{array}{l}1.026^{* *} \\
(0.015)\end{array}$ \\
\hline Company Age & $\begin{array}{l}1.015^{*} \\
(0.075)\end{array}$ & $\begin{array}{l}1.015^{*} \\
(0.073)\end{array}$ & $\begin{array}{l}1.017^{* *} \\
(0.050)\end{array}$ & $\begin{array}{c}1.005 \\
(0.648)\end{array}$ \\
\hline Market Cap & $\begin{array}{c}1.025 \\
(0.444)\end{array}$ & $\begin{array}{c}1.024 \\
(0.455)\end{array}$ & $\begin{array}{c}1.029 \\
(0.382)\end{array}$ & $\begin{array}{l}1.000 \\
(.)\end{array}$ \\
\hline Large Market Cap & $\begin{array}{l}0.999^{* * *} \\
(0.005)\end{array}$ & $\begin{array}{l}0.999^{* * *} \\
(0.006)\end{array}$ & $\begin{array}{l}0.999^{* *} \\
(0.011)\end{array}$ & $\begin{array}{c}1.000^{*} \\
(0.070)\end{array}$ \\
\hline Year Dummies & Yes & Yes & Yes & Yes \\
\hline $\begin{array}{l}\text { Chi-squared } \\
\text { Pseudo } R^{2}\end{array}$ & $\begin{array}{c}91.978^{* * *} \\
0.297\end{array}$ & $\begin{array}{c}86.870^{* * * *} \\
0.280\end{array}$ & $\begin{array}{c}99.180^{* * * *} \\
0.322\end{array}$ & $\begin{array}{c}30.831^{\text {*** }} \\
0.201\end{array}$ \\
\hline
\end{tabular}


Reporting odds ratios (exponentiated coefficients); ${ }^{*} p<0.10,{ }^{* *} p<0.05,{ }^{* * *} p<0.01$ 
Model (3) incorporates the variables used in all of the hypotheses. In this model, I still find support for the Law Firm Role and VC Private Benefits hypotheses. And I still find that the presence of a CEO-founder in non-Private-Equity-backed companies is associated with a higher likelihood that an issuer has an effective staggered board.

Model (4) displays a regression with DualClassControl as the dependent variable using the same independent variables as Model (3), which combined all of the hypotheses. The only independent variable of interest with a statistically significant exponentiated coefficient was Private Equity Backing, which indicated that PE-backed issuers are 1/10th as likely to go public with dual class control structures than non-PEbacked companies. This result suggests that there is not actually an efficiency-based reason for companies to go public with such takeover defenses. At least with respect to dual class control stock in private equity-backed firms, the results support the Institutional Investor Efficiency hypothesis. In unreported regressions, all of the hypotheses were individually tested using DualClassControl as the dependent variable to no avail.

Sensitivity tests were performed in unreported regressions to ensure the accuracy of these results. The explanatory power of my models actually increases when I exclude RLBOs and spin-offs from the sample. However, because these characteristics are unrelated to issuer adoption of takeover defenses, ${ }^{* * * * * * * * * * *}$ it would be inappropriate to exclude these valuable observations. The use of probit models instead of logistic models also does not materially affect the results. Finally, I reproduced the models in randomeffects logistic regressions using the 48-industry group classification introduced by Fama and French. ${ }^{. t+t+1+t+1}$ As the results were unaffected, I am confident that the reported results are not sensitive to changes in model specification.

\section{Implications}

\section{Institutional investors should exercise their influence over general partners and reevaluate the separation of investing from governance.}

Pension funds, mutual funds, and other institutional investors that invest in private equity and venture capital funds need to reevaluate their performance of stewards of good corporate governance. They should not continue their inconsistent behavior. If they truly believe in their corporate governance policies and positions that they have staked out publicly, such as their opposition to takeover market-insulating devices including

**********See Field \& Karpoff, supra note $* * * * * *$, at 1872.

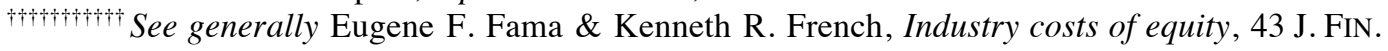
ECON. 153 (1997). 
staggered boards, then they should assess whether they are complying with such policies when they allow others to manage their investments.

A simple way that institutional investors such as pension funds can begin to fulfill this obligation is by informing the general partners of venture capital and private equity funds of their rationale for opposing takeover defenses such as staggered boards and of their expectations for general partners to take companies public in a manner consistent with good corporate governance. This does not entail that pension funds should actively participate in their external investments. All it necessitates is that they exercise their influence with respect to public company matters in a consistent matter across their portfolio. At a minimum, institutional investors should include matters of corporate governance in their investing criteria or, alternatively, disclose their explanation for investing in vehicles that do exactly what they publicly oppose.

Mutual funds should also be held accountable for their paradoxical behavior. Unlike pension funds, mutual funds have no middleman to blame. They should reevaluate their separation of investing and governance functions and ensure that they involve the necessary individuals when appropriate. For example, they should ensure that their corporate governance personnel are aware of governance arrangements in portfolio companies that are being taken public instead of only relying on such personnel in formal proxy voting situations. And if they believe that the principles in their proxy voting policy should not apply to these IPO issuers, then they should at least disclose that fact and the rationale behind it.

\section{Staggered boards should have sunset provisions.}

While the merits of takeover defenses for newly public firms can be debated, two things are certain. First, it is evident that the majority of IPO issuers go public with staggered boards and it cannot be said that doing so is always inefficient. Second, public companies of all types and sizes are eliminating their staggered boards in response to almost-universal investor opposition to such provisions. Regardless of whether ESBs might be optimal for a large number of issuers, it is clear that it is not optimal for these issuers to keep them in perpetuity. Therefore, issuers with ESBs should go public with provisions that phase out the staggered board or automatically put declassification up for a shareholder vote after a certain amount of time.

Under the status quo, an expensive routine commonly plays itself out: Company $X$ goes public with an ESB. A shareholder of X submits a precatory proposal calling for the board to declassify itself. ISS and institutional investors unanimously support the proposal. The proposal passes at the annual meeting. A year later, Company X puts a management proposal to amend the charter to declassify the board on the proxy 
statement. The proposal passes. Another year later, the directors up for election are only elected for a one-year term. And two years after that, the entire board is finally up for election on an annual basis.

This customary dance is wasteful of both companies' and shareholders' resources, costing companies as much as $\$ 250,000 .{ }^{*}$ Instead of repeating this charade, issuers that find it optimal to go public with an ESB should include a charter provision that automatically phases in annual elections after a certain period of time, absent a shareholder vote to retain an ESB. Professor Bebchuk suggested a similar solution in the past and concluded that the scarcity of such provisions was rooted in bounded attention

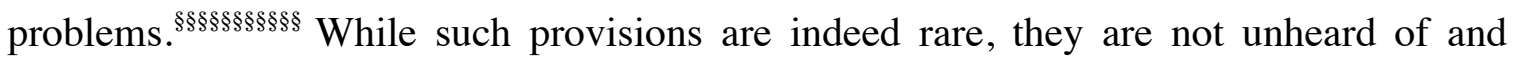
were present in some of the charters of issuers backed by private equity firms in the sample. As discussed earlier, however, these charters usually phased-in entrenching mechanisms rather than phasing them out.

While issuers should be given the chance to do this on their own, legislative intervention may prove to be necessary. On one hand, issuers can arguably capture additional value during their IPOs if they have built-in sunset provisions for their staggered boards. Recall that at least one study has found that positive abnormal returns were observed around public company announcements to switch to annual elections. ${ }^{* * * * * * * * * * *}$ Issuers will presumably be able to capture these returns in the form of a slightly higher IPO price. On the other hand, the bounded attention problems that Bebchuk identified may inhibit the widespread adoption of such provisions. If that turns out to be the case, then the Delaware General Assembly should consider legislative intervention that still preserves issuer choice by allowing for shareholder votes to eliminate an automatic sunset in order to preserve an ESB.

\section{CONCLUSION}

A large sample of firms that went public from 2008 to 2012 reveals that variation in IPO companies' takeover defenses is largely determined by the reliance of two agents in the IPO process: lawyers and financial sponsors. Seventy-seven percent (77\%) of companies went public with either a classified board or a dual class capital structure

According to a 1997 questionnaire used by the SEC, companies estimated that the total direct cost (including internal costs, legal fees, and printing expenses) of including a shareholder proposal is \$87,000. See Final Rule: Amendments to Rules on Shareholder Proposals, SEC Exchange Act Rel. No. 34-40018, 63 Fed. Reg. 29106, 29114 (May 28, 1998) (codified at 17 C.F.R. pt. 240). Adjusted for inflation, the cost comes out to $\$ 123,595$ in 2012 . I assumed that this cost would be incurred twice: first for the shareholder proposal and then again for the subsequent management proposal.

$\S \S \S \S \S \S \S \S \S \S$ Bebchuk, supra note $* * * * * * * * * * * * * * *$, at 752-53.

See supra note $\S \S \S \S \S \S \S \S$ and accompanying text. 
where insiders retained the controlling class of shares, two of the most powerful antitakeover devices. While only $16 \%$ of companies the S\&P 500 have classified boards, $75 \%$ of companies in the sample went public with classified boards. The sample also illustrates the "ISS Effect," a significant drop-off in the rate of classification for the largest companies caused by anticipated pressure from institutional shareholders.

I find strong empirical support for the theory that a law firm's role in public M\&A transactions - i.e. the number of transactions it represents acquirers or targets - affects the likelihood that its clients go public with takeover defenses in place. In every model, there was a statistically significant positive correlation between the number of M\&A targets represented by an issuer's legal counsel and the probability that the issuer adopts an ESB. I also find that a law firm's overall proficiency in M\&A no longer correlates with takeover defenses. The lack of a consensus amongst the most knowledgeable law firms regarding the adoption of takeover defenses prevents us from looking to them for an efficiency-based explanation of the variation in adoption. Instead, it indicates that anecdotal evidence and the framing of the issue within law firms help determine IPO legal advice on defenses.

There is also substantial evidence that financial sponsors such as private equity and venture capital funds play a significant role in whether their portfolio companies adopt takeover defenses. A staggering $90 \%$ of VC-backed companies went public with an ESB while only $51 \%$ of PE-backed companies did. PE-backed issuers tend to have some more shareholder-friendly charter and bylaw provisions such as those allowing shareholders to act by written consent or call a special meeting than VC-backed have. However, this likely is not due to the goodness of the hearts of private equity sponsors; these provisions plausibly allow private equity firms to maintain their flexibility while they still hold shares. At the other end of the spectrum, $88 \%$ of VC-backed companies went public with supermajority requirements to amend bylaws that work to insulate management from shareholders. A small number of PE-backed companies went public with charter provisions that were conditioned on the level of PE ownership. Most of these were not shareholder friendly; they merely gave veto rights to PE funds while they still held shares but leave shareholders out in the cold after the PE funds sell their positions.

There were some observable differences in the characteristics of companies taken public by venture capital and private equity firms. High tech companies accounted for around $72 \%$ of VC-backed companies while only accounting for $21 \%$ of PE-backed companies. PE-backed companies were, on average, twice as old as VC-backed companies. PE-backed issuers also had substantially more assets before the offering than VC-backed companies, although VC-backed companies had higher market caps, on average. 
After controlling for the characteristics of the individual companies, venture capital backing still has a strong statistically significant relationship with the probability that a company goes public with an ESB. In most models, venture capital backing increased the odds that a given IPO issuer had an ESB by over 700\%. These results are consistent with the Private Benefits hypothesis, which predicted that financial sponsors would take companies public with takeover defenses in order to maintain private benefits of control at the expense of other shareholders. Venture capital firms typically give up most of their formal control rights at an IPO and likely use takeover defenses such as an ESB to insulate the company so that the venture fund can exert influence that is disproportionate to its decreased shareholders as they sell off their stakes.

Private equity backing, however, does not have a statistically significant correlation with the presence of an ESB. Because private equity and venture capital funds are similarly structured and both are experienced players in the IPO market, this result was unexpected. A plausible explanation for the difference is that private equity firms have significantly more experience in the public markets (through transactions such as LBOs and PIPEs) than venture capital firms. They therefore are likely more aware of the negative consequences of takeover defenses such as ESBs and less likely to recommend such devices. Additionally, management teams may be more indispensable to firm value in VC-backed firms than in PE-backed firms.

If private equity-backed issuers and venture capital-backed issuers adopted takeover defenses at a similar rate, it would provide substantial evidence that takeover defenses are generally optimal for newly public companies (even though they may destroy value later on in a public company's life). However, my results indicate that it is no longer generally optimal for firms to go public with takeover defenses. On the other hand, one cannot discount the fact that a meaningful number of firms continue to go public with these devices. It would therefore be premature to conclude that it is always inefficient for an issuer to go public with takeover defenses. 


\section{APPENDix A Selected Charter Provisions}

\begin{tabular}{|c|c|c|c|}
\hline & & & \\
\hline & & & \\
\hline \multicolumn{4}{|c|}{$\begin{array}{l}\text { referred Stock then outstanding, any director or the } \\
\text { any time, but only for cause and only by the affirmative } \\
\text { voting power of the then issued and outstanding shares } \\
\text { election of directors (the "Voting } \\
\text { ess Stockholders (as defined in Part (a) of Article } \\
\text { in Part (a) of Article ELEVENTH) at least forty percent } \\
\text { any director or the entire Board of Directors may be } \\
\text { by the affirmative vote of the holders of at least a } \\
\text { g Voting Shares. The vacancy in the Board of Directors } \\
\text { olders or, if not so filled, by the Board of Directors as }\end{array}$} \\
\hline
\end{tabular}

\begin{tabular}{|c|c|c|c|}
\hline Inc. & Sandler & Cerberus & $\operatorname{Pr}$ \\
\hline \multicolumn{4}{|c|}{$\begin{array}{l}\text { Prior to the } 50 \% \text { Trigger Date, any director may be designated for removal and removed from office at any time } \\
\text { with or without cause, by stockholders having the right to vote at least } 50 \% \text { in voting power of the outstanding } \\
\text { Voting Stock, voting together as a single class. From and after the } 50 \% \text { Trigger Date, any director may be } \\
\text { removed from office at any time, but only with cause and only if approved (1) by the affirmative vote of } \\
\text { stockholders having the right to vote at least two-thirds }(2 / 3) \text { in voting power of the outstanding Voting Stock, } \\
\text { voting together as a single class, or (2) if the Board of Directors recommends to the stockholders removal of a } \\
\text { director for cause, by the affirmative vote of stockholders having the right to vote at least a majority in voting } \\
\text { power of the outstanding Voting Stock, voting together as a single class. }\end{array}$} \\
\hline
\end{tabular}

\begin{tabular}{|c|c|c|c|}
\hline o. & S11 & Blackstone & y \\
\hline \multicolumn{4}{|c|}{$\begin{array}{l}\text { Preferred Stock of the } \\
\text { as the case may be) may } \\
\text { in voting power of all } \\
\text { directors, voting as a } \\
\text { al owners, in the } \\
\text { hares of stock of the } \\
\text { such directors may be } \\
\text { of all outstanding shares } \\
\text { a single class. For } \\
\text { all be determined } \\
\text { ded. }\end{array}$} \\
\hline
\end{tabular}

\begin{tabular}{|l|l|l|l|}
\hline $\begin{array}{l}\text { Cobalt International } \\
\text { Energy }\end{array}$ & Davis Polk & $\begin{array}{l}\text { Carlyle/Riverstone; } \\
\text { Goldman Sachs; First } \\
\text { Reserve; KERN }\end{array}$ & Private Equity \\
\hline
\end{tabular}

From and after the Effective Date, except as otherwise provided in the terms of any series of Preferred Stock entitled to separately elect directors, the directors shall be divided into three classes, designated Class I, Class II and Class III. Each class shall consist, as nearly as may be possible, of one-third of the total number of directors constituting the entire board of directors. The Board of Directors is hereby authorized to assign members of the Board of Directors in office at the Effective Date to such classes. Except as otherwise provided in the certificate of incorporation, each director shall serve for a term ending on the date of the third annual meeting of stockholders next following the annual meeting at which such director was elected.

"Effective Date" shall mean the first date on which the Sponsors and their affiliates no longer beneficially own more than $50 \%$ of the outstanding shares of Common Stock of the Corporation or the Corporation no longer qualifies as a "controlled company" under Section 303A of the New York Stock Exchange Listed Company Manual as in effect on December 15, 2009." 
“Sponsors” means Carlyle/Riverstone, Goldman Sachs, First Reserve and KERN.

\section{APPENDIX B}

\section{Proxy Voting Policies for Select Mutual Funds and Pension Funds}

\section{Fidelity ("FMR"): ${ }^{+\dagger+1+\dagger+1+1+\dagger}$}

FMR will generally vote against a proposal to adopt or approve the adoption of an AntiTakeover Provision unless [specified conditions are met].

FMR will generally vote in favor of a proposal to eliminate an Anti-Takeover Provision unless:

D. In the case of proposals to declassify a board of directors, FMR will generally vote against such a proposal if the issuer's Articles of Incorporation or applicable statutes include a provision whereby a majority of directors may be removed at any time, with or without cause, by written consent, or other reasonable procedures, by a majority of shareholders entitled to vote for the election of directors.

\section{Vanguard:}

The funds will generally support proposals to declassify existing boards (whether proposed by management or shareholders) and will block efforts by companies to adopt classified board structures, in which only part of the board is elected each year.

\section{Alberta Investment Management Corp (“AIMCo"): :}

\section{A HIGH PERFORMANCE BOARD IS ACCOUNTABLE AND INDEPENDENT}

Guideline One: Facilitate shareholder democracy . . . .

- All directors should be up for election each year - board terms should not be staggered.

\section{Ontario Teachers' Pension Plan:}

We prefer the annual election of all directors. We will generally not support proposals that provide for staggered terms for board members....

We see many disadvantages with a classified system. Staggered terms for board member make it more problematic for shareholders to make fundamental changes to the composition and behaviour of boards, by making it extremely difficult for any challenge to, or change in, board control. In circumstances of deteriorating corporate performance, this difficulty could result in a permanent impairment of long-term shareholder value.

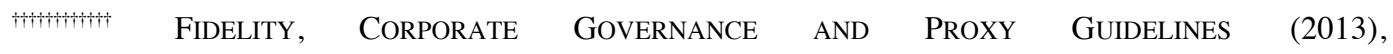
http://personal.fidelity.com/myfidelity/InsideFidelity/InvestExpertise/governance.shtml.

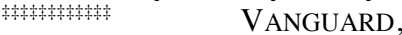
PROXY
VOTING
GUIDELINES
(2013), https://investor.vanguard.com/about/vanguards-proxy-voting-guidelines.

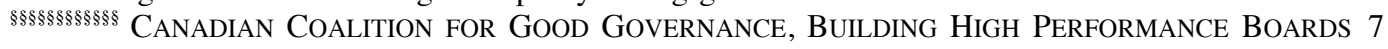
(2010),

http://www.ccgg.ca/site/ccgg/assets/pdf/CCGG_Building_High_Performance_Boards_Final_March_2010.pdf.

************** ONTARIO Teachers' Pension Plan, GoOd Governance IS GoOd Business: Corporate

GOVERNANCE PRINCIPLES AND PROXY VOTING GUIDELINES 26 (2013),
http://www .otpp.com/documents/10179/20940/TeachersCorpGovE.pdf/cfca9682-9368-4cf4-96ce-fe5381d5647e.
} 